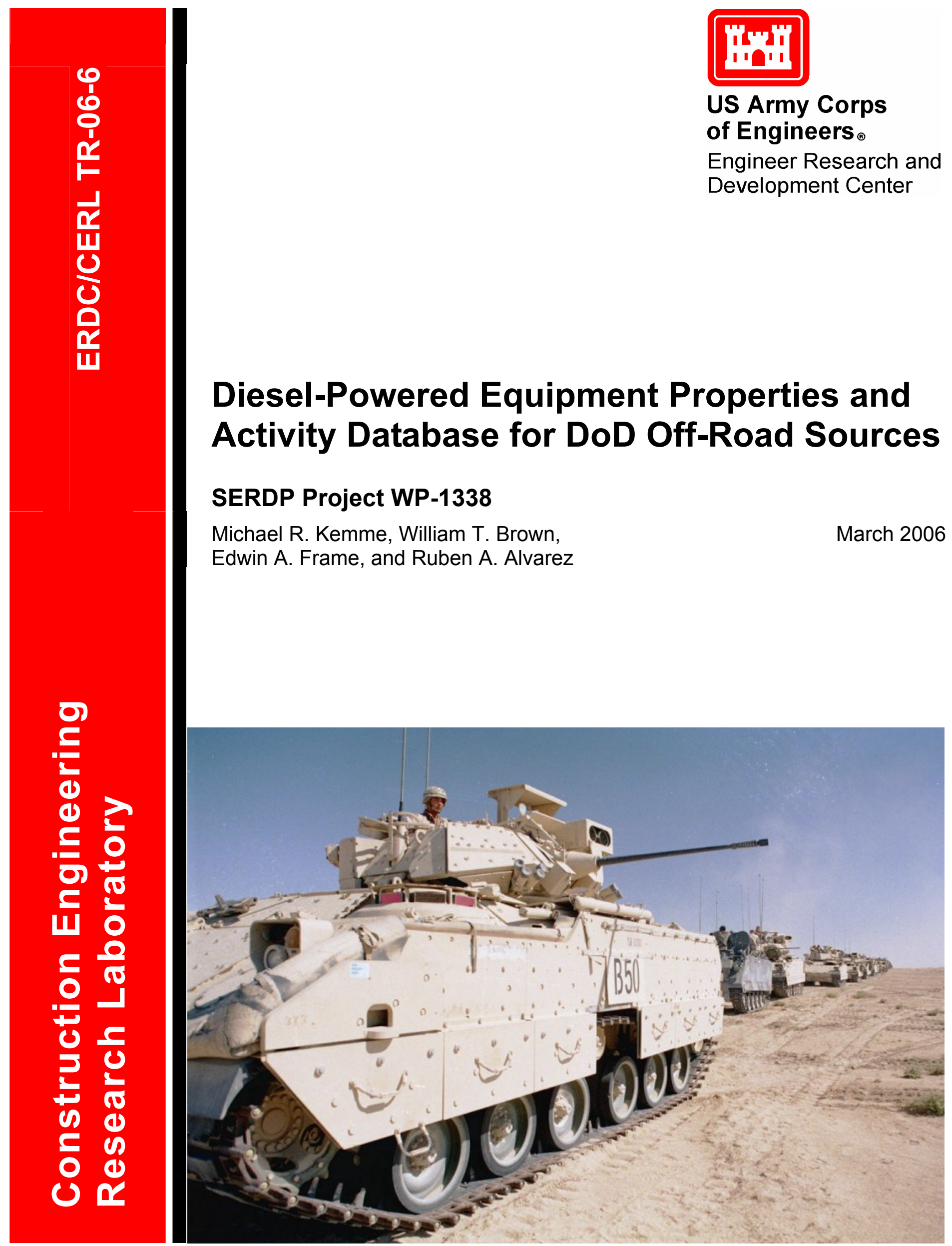




\section{Diesel-Powered Equipment Properties and Activity Database for DoD Off-Road Sources}

\section{SERDP Project WP-1338}

Michael R. Kemme and William T. Brown

U.S. Army Engineer Research and Development Center

Construction Engineering Research Laboratory

PO Box 9005

Champaign, IL 61826-9005

Edwin A. Frame and Ruben A. Alvarez

U.S. Army Tank-Automotive Research, Development and Engineering Center

Fuels and Lubricants Research Facility, Southwest Research Institute

P.O. Drawer 28510

San Antonio, TX 78228-0510

Final Report

Approved for public release; distribution is unlimited.

Prepared for: Strategic Environmental Research and Development Program

901 North Stuart Street, Suite 203

Arlington, VA 22203-1821

Under: $\quad$ SERDP Project WP-1338 
ABSTRACT: A database of Department of Defense diesel engine powered off-road equipment was developed using Micro-soft $₫$ Access database development tools. The database contains information about fuels, equipment, engines, inventories, usage, and fuel consumption that was obtained from many disparate sources. This database was developed to support the SERDP-funded project Characterization of Off-Road Emissions of Criteria Pollutants (WP-1336). The database was used to prioritize the equipment contained in the WP-1336 test matrix and will later be used as a source of information for the WP-1336 engine emission estimation tool. Data analysis has shown that the top ten fuel consuming engines account for more than 90 percent of fuel usage for the Army and more than 80 percent for the U.S. Marine Corps. Therefore, emission tests performed on a limited number of off-road diesel engines can provide a fairly complete picture of emissions from the entire population of military off-road sources. The database includes an interface that allows users to view data in onscreen forms or analyze data using built-in reports. The database and interface are intended as resources for anyone interested in examining, filtering, querying, or analyzing the collected data.

DISCLAIMER: The contents of this report are not to be used for advertising, publication, or promotional purposes. Citation of trade names does not constitute an official endorsement or approval of the use of such commercial products. All product names and trademarks cited are the property of their respective owners. The findings of this report are not to be construed as an official Department of the Army position unless so designated by other authorized documents. 


\section{Executive Summary}

Emissions from combat and tactical equipment engines during training activities contribute to local and regional air pollution. The emissions from these Department of Defense (DoD) sources are not well understood, and they will likely differ significantly from the emissions of similar civilian sources. Emission differences are probable because the fuels, vehicle usage patterns, and engine technologies are different. Although many DoD sources are exempt from regulations that limit diesel engine emissions from comparable civilian sources, DoD installations still must be able to answer regulatory questions about the impacts these sources have on air pollution problems. An emissions estimation capability will be useful to installation managers and designers of military training ranges in preventing excessive emissions from off-road sources and developing recommendations for reducing these emissions.

To further the creation of an off-road diesel engine emission estimation capability, the Strategic Environmental Research and Development Program (SERDP) funded the project WP-1336, Characterization of Off-Road Diesel Emissions of Criteria Pollutants and WP-1338, which is described in this report. The objective of WP-1338 was to develop a database of DoD off-road sources and their activity. The WP-1338 database was designed to directly support WP-1336 by serving as input during the selection of off-road equipment to be tested. The selection will be based on equipment inventories, usage levels, fuel consumption, and planned future use. Detailed tactical equipment information ensures that the equipment tested represents a larger population of the equipment types. Fuel consumption data allow an estimate of engine use that should correspond better with engine emissions than with other activity measurements such as vehicle miles driven or hours of operation. The database will also be used as a component of the base-wide emissions estimation software tool being developed in WP-1336. The database can serve as a source of equipment characteristics and activity level information that is required by the emission estimation methods used in the software tool.

Another objective of this work was to develop a database that could function independently from the base-wide emission estimation tool mentioned above. This objective was achieved by including a simple user interface that allows onscreen filtering and sorting of data and also allows users to generate reports that group and summarize the data. 
To accomplish the project's objectives, researchers (1) collected data on DoD fuels, equipment, diesel engines, and equipment activity, (2) designed and populated a database to store the collected data, (3) developed a user interface, and (4) analyzed data to determine which off-road sources were likely to be major emission contributors. Fuel information was obtained from fuel surveys completed between 1998 and 2003 and performed first by TRW Petroleum Technologies and later by Northrop Grumman Mission Systems. Equipment data were collected from a wide variety of sources including the Federal Logistic (FED LOG) Interactive Database system, technical manuals for equipment; Supply Bulletins listing Army equipment and fuel consumption; a U.S. Air Force equipment database; and the Navy Construction, Automotive and Specialized Equipment Management Information System (CASEMIS). Engine information sources included the FED LOG Interactive Database, equipment technical manuals, and engine manufacturers' Internet sites. The sources of equipment activity and inventory information for this work were the Operating and Support Management Information System (OSMIS) for the Army and the U.S. Marine Corps (USMC) section of the Navy Visibility and Management of Operating and Support Costs (VAMOSC) system. Activity information was collected for Fiscal Years (FY) 2001 through 2003 for both the Army and USMC. References to specific data sources and a more detailed description of the data collection process are included.

The database was designed and developed using Microsoft (MS) Access 2000 since Access is readily available to military personnel as one of the MS Office software applications. The database contains tables for installations, fuels, equipment, engines, and equipment activity and inventory. The tables are linked to one another and referential integrity is activated for each of the relationships in the database so that data integrity will be maintained. The database file containing the originally collected data is encrypted and password protected to prevent this information from being changed so that a baseline of information is maintained. This report gives more details of the overall database design and the design and population of each of the database tables.

The user interface was also developed using MS Access 2000 and is contained in a separate database file. The user interface is a collection of MS Access tables, forms, queries, reports, and Visual Basic for Applications code. The user interface is linked to a temporary database that contains either the originally collected dataset or a dataset previously created by a user. In either case, the temporary database allows the initially opened version of the data to be maintained until the user specifically requests that the dataset be saved to an existing database name or a new file name. However, the interface will not allow the originally collected dataset to be overwritten. 
The interface contains individual forms for viewing and editing data from the Installation, Fuels, Engine, Equipment, and Equipment Activity and Inventory tables. Each form uses the same custom toolbar that provides users the ability to sort, search, filter, edit, and navigate data. The interface also contains a report generation form, which allows users to select among several reports and presents options for setting conditions on a selected report. The conditions will vary depending on the report that has been selected, and the conditions default to the most inclusive. The form provides users the choice of previewing the report onscreen or printing it immediately. The form includes reports for engine, equipment, and installation fuel usage with varying degrees of detail.

The report generation feature of the user interface was used to perform preliminary data analysis to determine which off-road diesel-powered sources are likely to be the largest air pollutant emitters. Engine fuel consumption reports were generated for combined Army and USMC use and for individual service use for FY2001 through FY2003 and for just FY2003. The engine fuel usage reports are useful because they tend to group and summarize data from many similar types of equipment that use the same diesel engine. The reports for FY2003 are probably more representative of current usage patterns since FY2003 is the most recent dataset.

The engine fuel consumption reports did show that a relatively small number of engines account for a large percentage of fuel usage with the top ten fuel-consuming engines accounting for over 90 percent of fuel usage for the Army and over 80 percent for the USMC. Therefore, emission tests on a limited number of off-road diesel engines can provide a fairly complete picture of emissions from the entire population of military off-road sources. For vehicles, the High-Mobility Multipurpose Wheeled Vehicle, Heavy Expanded Mobility Tactical Truck, 5-ton trucks, Light Armored Vehicle, Stryker, Family of Medium Tactical Vehicles, and the Bradley Fighting Vehicle all show up as important engine emission sources. M1A1 and M1A2 tanks are also large emissions sources but are powered by a turbine engine that would not likely be classified as a diesel off-road source. Although generator sets are not prominent in combined Army and USMC usage reports, they are artificially underrepresented because Army generator usage is not recorded correctly in OSMIS. The data from the USMC portion of the Navy VAMOSC system indicate that 60-, 30-, and 10-kW generator sets are major engine emission sources, and it is very likely that this same level of usage occurs within the Army and throughout DoD.

Because of the user interface, the database is potentially useful to a wide population that is not necessarily familiar with databases or MS Access. The interface allows database access to anyone interested in obtaining or analyzing data about DoD fuels, off-road equipment, diesel engines, and off-road equipment usage. The data- 
base, the interface, and this report are available to anyone with DoD menu privileges in the permanent shared file library section of the Defense Environmental Network and Information Exchange website. 


\section{Contents}

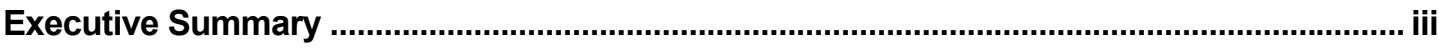

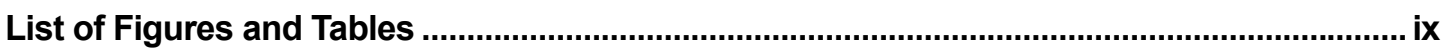

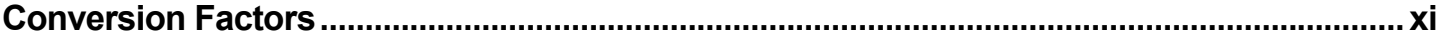

Preface

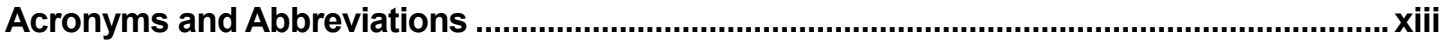

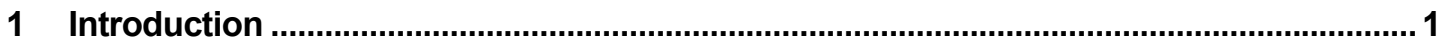

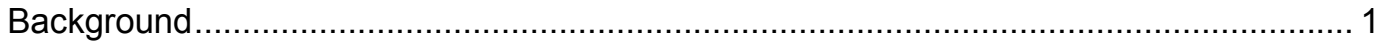

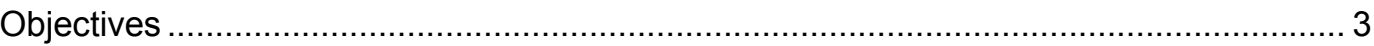

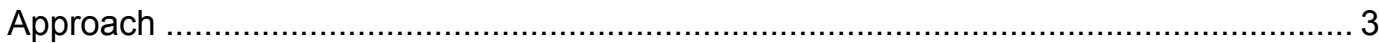

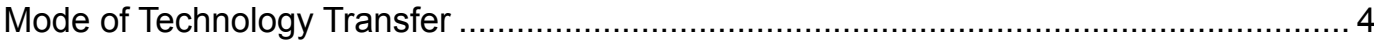

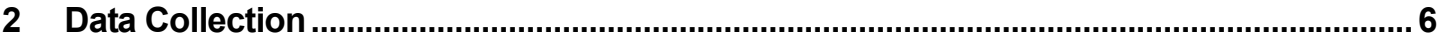

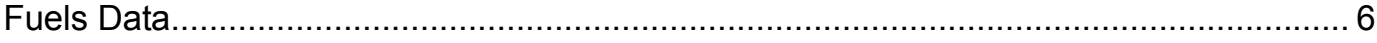

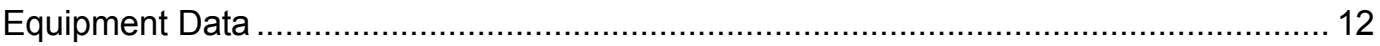

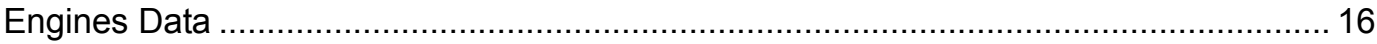

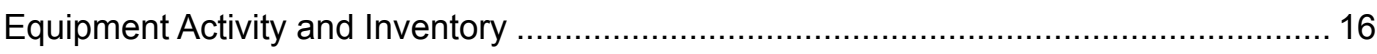

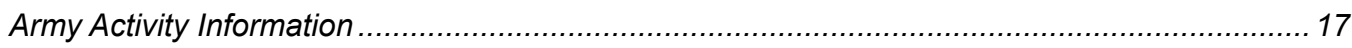

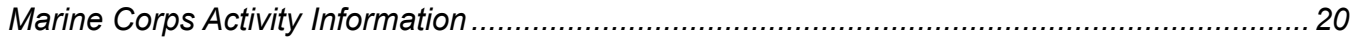

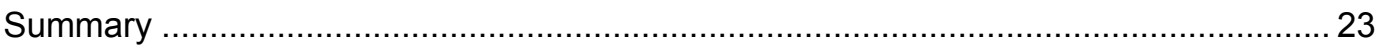

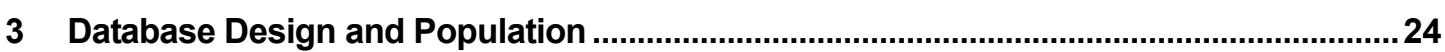

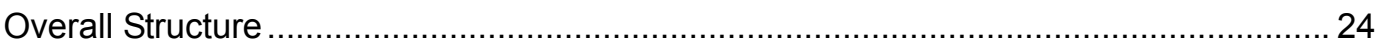

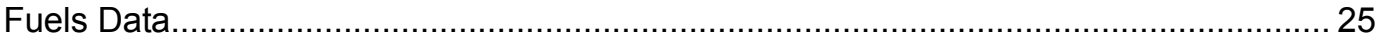

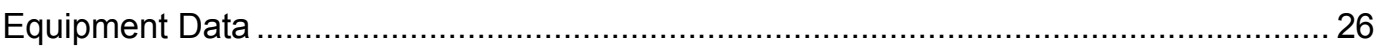

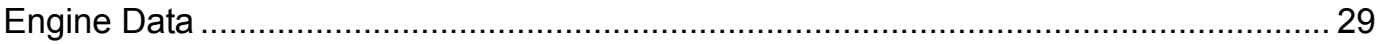

Equipment Activity and Inventory Data.............................................................. 30

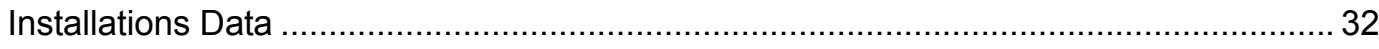

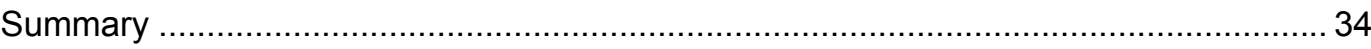

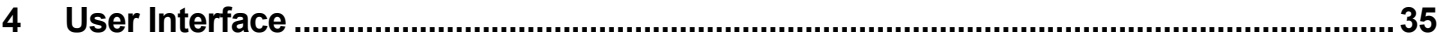

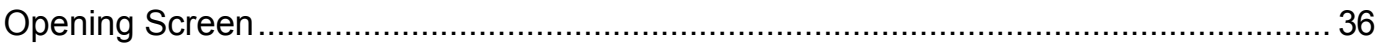

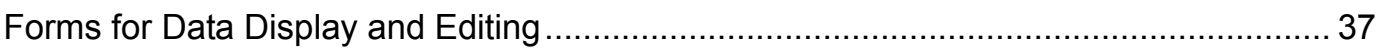




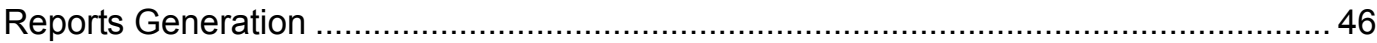

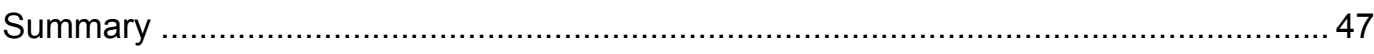

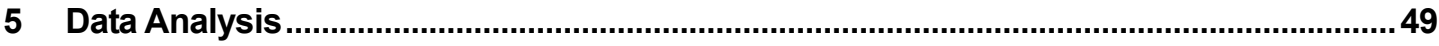

Army and USMC Emission Testing Priority ................................................................. 49

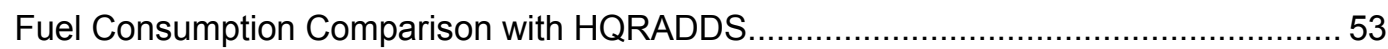

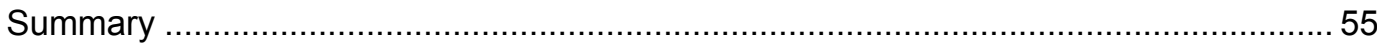

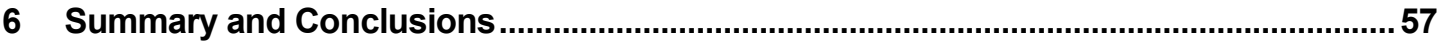

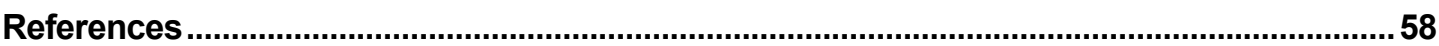

Appendix: Engine Fuel Consumption With Equipment List Reports for All Services

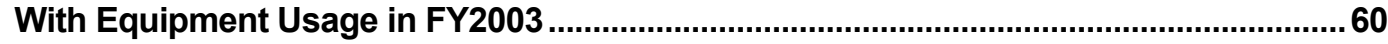

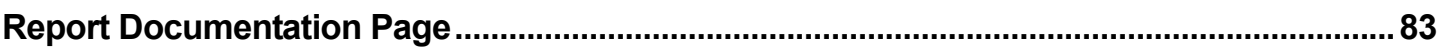




\section{List of Figures and Tables}

\section{Figures}

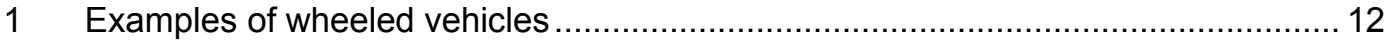

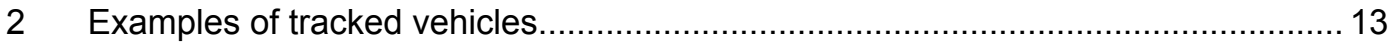

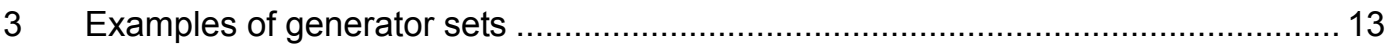

4 Example of OSMIS data imported into an MS Excel spreadsheet ......................... 19

5 First page of query results showing activity and fuel usage information from the

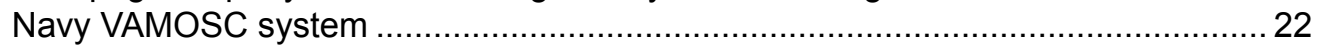

6 First page of query results showing inventory information from the Navy

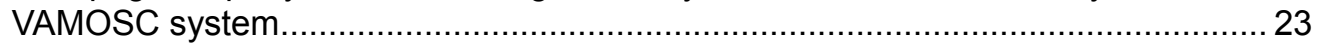

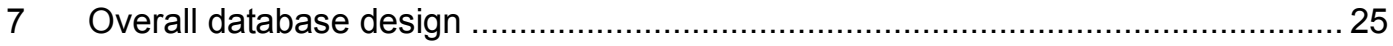

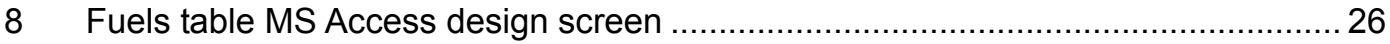

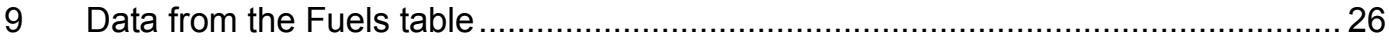

10 MS Access design screen for the Equipment table............................................. 27

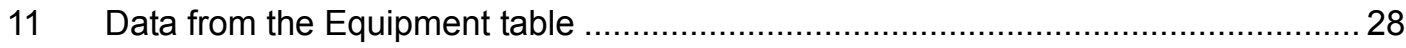

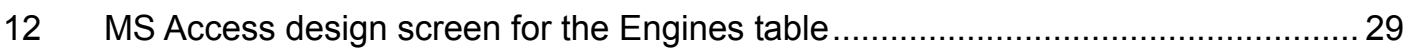

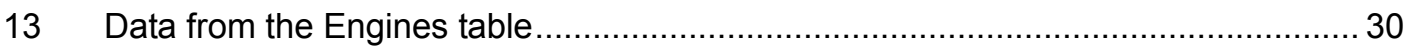

14 MS Access design screen for the Equipment Activity and Inventory table ...............31

15 Data from the Equipment Activity and Inventory table ......................................... 31

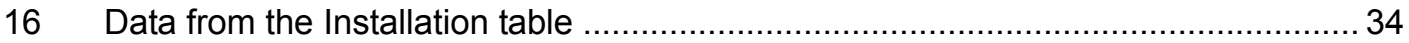

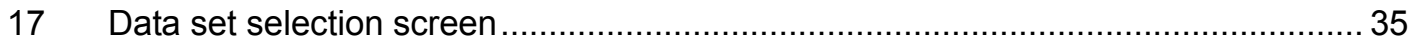

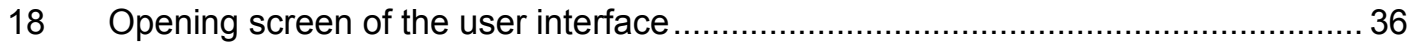

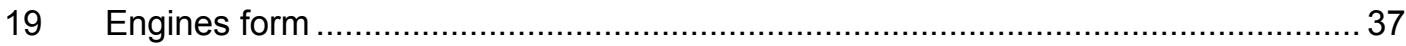

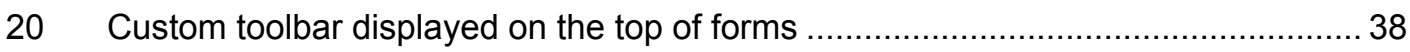

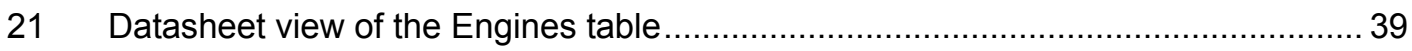

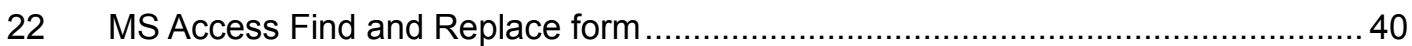

$23 \quad$ Filter by form conditions and results for the Engines table .................................. 42

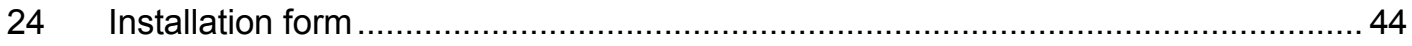

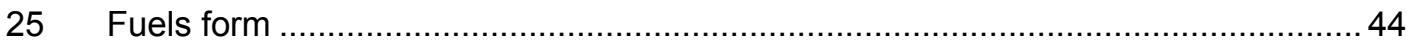

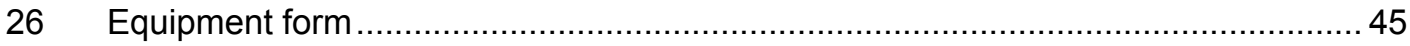

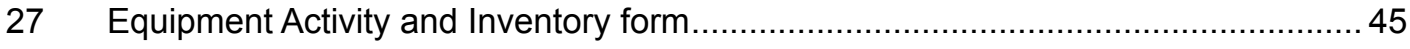

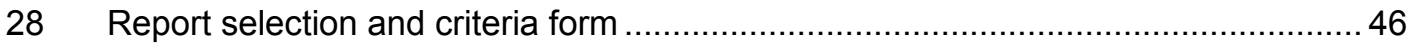


29 Report preview screen of the Engine Fuel Consumption report for 2003 Army data 47

30 Installation fuel consumption in FY2003 54

\section{Tables}

1 Pollutant contributions from highway and off-road engines 1

2 Summarized data for aviation turbine fuels (averaged analyses results of 30 samples from 6 different companies throughout the United States).

3 Summarized national data for 1-D on-highway diesel fuels for 2003.

4 Summarized 2003 on-highway diesel fuel data for eastern, southern, and central regions

5 Summarized 2003 on-highway 2-D diesel fuel data for the nation and the rocky mountain and western regions

6 Summarized 2003 off-highway 2-D diesel fuel data

7 Summarized 2002 data for summer motor gasoline grades (averaged analyses results of 551 motor gasoline samples from service stations throughout the United States).....

8 Summarized 2002 and 2003 data for winter motor gasoline grades (averaged analyses results of 359 motor gasoline samples from service stations throughout the United States)

9 Actions performed by each of the buttons in the custom toolbar.....

10 Top 20 Army and USMC off-road diesel engine fuel consumptions for FY20012003

11 Top 20 Army and USMC off-road diesel engine fuel consumptions for FY2003...... 51

12 Top 10 Army off-road diesel engine fuel consumptions for FY2003 ....................... 52

13 Top 10 USMC off-road diesel engine fuel consumptions for FY2003 ..................... 52

14 Installation fuel usage in gallons as reported in OSMIS and HQRADDS .................55 


\section{Conversion Factors}

Non-SI* units of measurement used in this report can be converted to SI units as follows:

\begin{tabular}{|l|c|l|}
\hline Multiply & By & To Obtain \\
\hline degrees Fahrenheit & $(5 / 9) \times\left({ }^{\circ} \mathrm{F}-32\right)$ & degrees Celsius \\
\hline gallons (U.S. liquid) & 0.003785412 & cubic meters \\
\hline horsepower (550 ft-lb force per second) & 745.6999 & watts \\
\hline cubic inches & 0.016387 & liters \\
\hline miles (U.S. statute) & 1.609347 & kilometers \\
\hline pounds (mass) & 0.4535924 & kilograms \\
\hline tons (2,000 pounds, mass) & 907.1847 & kilograms \\
\hline
\end{tabular}

\footnotetext{
*Système International d'Unités (“International System of Measurement”), commonly known as the "metric system."
} 


\section{Preface}

This work was conducted for the Strategic Environmental Research and Development Program (SERDP) as Compliance Project WP-1338 "Tailpipe Emission Estimation for DoD Off-Road Sources." The authors thank Dr. Robert W. Holst, SERDP Compliance Program Manager and Bradley P. Smith, SERDP Executive Director, for their support during this program.

The work was performed by the Environmental Processes Branch (CN-E) of the Installations Division (CN), Construction Engineering Research Laboratory (CERL) and the U.S. Army Tank-Automotive Research, Development and Engineering Center, Fuels and Lubricants Research Facility (TFLRF), Southwest Research Institute. The CERL Principal Investigator is Michael R. Kemme. Dr. K. James Hay is Acting Chief, CN-E, and Dr. John T. Bandy is Chief, CN. The associated Technical Director is William D. Severinghaus, CV-T. The Acting Director of CERL is Dr. Ilker R. Adiguzel.

CERL is an element of the U.S. Army Engineer Research and Development Center (ERDC), U.S. Army Corps of Engineers. The Commander and Executive Director of ERDC is COL James R. Rowan, and the Director of ERDC is Dr. James R. Houston. 


\section{Acronyms and Abbreviations}

$\begin{array}{ll}\text { AAV } & \text { Assault Amphibian Vehicle } \\ \text { AMDF } & \text { Army Master Data File } \\ \text { AOAP } & \text { Army Oil Analysis Program } \\ \text { APC } & \text { Armored Personnel Carrier } \\ \text { CASEMIS } & \text { Construction, Automotive and Specialized Equipment } \\ \text { CBS-X } & \text { Continuing Balance System - Extract } \\ \text { CDROM } & \text { Compact Disc - Read Only Memory } \\ \text { CERL } & \text { Construction Engineering Research Laboratory } \\ \text { CONUS } & \text { Continental United States } \\ \text { DENIX } & \text { Defense Environmental Network and Information Exchange } \\ \text { DMFA } & \text { Depot Maintenance Float Allowance } \\ \text { DoD } & \text { Department of Defense } \\ \text { DVD } & \text { Digital Video Disk } \\ \text { EEAP } & \text { Enhanced Equipment Allowance Pool } \\ \text { EPA } & \text { Environmental Protection Agency } \\ \text { ERDC } & \text { Engineer Research and Development Center } \\ \text { FED LOG } & \text { Federal Logistics (Interactive Database) } \\ \text { FLIS } & \text { Federal Logistics Information System } \\ \text { FMTV } & \text { family of medium tactical vehicles } \\ \text { FORSCOM } & \text { U.S. Forces Command } \\ \text { HEMTT } & \text { heavy expanded mobility tactical truck } \\ \text { HMMWV } & \text { high mobility multi-purpose wheeled vehicle } \\ \text { LAV } & \text { interim armored vehicles } \\ \text { LIF } & \text { Logistics Support Activity } \\ \text { LOFrated Database }\end{array}$


MDS Mission Design Series

MEF Marine Expeditionary Force

MOB Mobilization Allowance

MPF Maritime Prepositioning Force

Net WRMR Net War Reserve Materiel Requirement

NIIN National Item Identification Number

NITC Naval Facility Information Technology Center

OCONUS outside the Continental United States

O\&S operating and support

OSD Office of the Secretary of Defense

OSMIS Operating and Support Management Information System

PMR Provisioning Master Record

POL Petroleum, Oils, and Lubricants

PU power unit

Reserve T/A Reserve Training Allowance (Pool)

SERDP Strategic Environmental Research and Development Program

TARDEC Tank-Automotive Research, Development and Engineering Center

TAMCN table of authorized material control number

TFLRL TARDEC Fuels and Lubricants Research Facility

TQG tactical quiet generator

ULLS-G Unit Level Logistics System - Ground

USAF U.S. Air Force

USMC U.S. Marine Corps

VAMOSC Visibility and Management of Operating and Support Costs 


\section{Introduction}

\section{Background}

Emissions from combat and tactical equipment engines during training activities contribute to local and regional air pollution. The emissions from these Department of Defense (DoD) sources are not well understood, and they likely differ significantly from the emissions of similar civilian sources. Emission differences are probable because the fuels, vehicle usage patterns, and engine technologies are different. Although many DoD sources are exempt from regulations that limit diesel engine emissions from comparable civilian sources, DoD installations still must be able to answer regulatory questions about the impacts these sources have on air pollution problems. For example, the General Conformity provisions of the Clean Air Act require DoD installations to estimate engine emission impacts from combat and tactical equipment after obtaining new missions that include these sources. An emissions estimation capability will also be useful to installation managers and designers of military training ranges in preventing excessive emissions from off-road sources and developing recommendations for reducing these emissions.

In 1998, the U.S. Environmental Protection Agency (EPA) adopted more stringent standards for off-road diesel engines to reduce harmful emissions (63 FR 56968, 23 October 1998). The stricter standards were a response to growing concerns about the contributions these sources make to air pollution problems. Table 1 compares off-road and highway emission contributions to the national emission inventory for 2000 and shows that off-road engines contribute almost as much air pollution as highway engines. Most civilian off-road engines are diesel and virtually all of the military's off-road engines are diesel.

Table 1. Pollutant contributions from highway and off-road engines.

\begin{tabular}{lrr}
\hline Pollutant & \multicolumn{2}{c}{$\begin{array}{c}\text { Emissions (thousands of tons) } \\
\text { Highway }\end{array}$} \\
\hline Off-Road \\
\hline Nitrogen oxides & 7,988 & 5,461 \\
Hydrocarbons & 3,772 & 3,677 \\
Carbon monoxide & 49,701 & 29,514 \\
Particulate matter & 459 & 240 \\
\hline
\end{tabular}

Source: EPA 2000. 
Air pollutant emissions from off-road sources are currently estimated using the U.S. EPA's NONROAD model. The NONROAD model contains steady-state engine emission factors based on engine power and model year. The emission factors are then adjusted to account for deterioration with age, adjustment for transient-use, and fuel sulfur levels. The NONROAD model estimates emissions of carbon monoxide $(\mathrm{CO})$, carbon dioxide $\left(\mathrm{CO}_{2}\right)$, hydrocarbons $(\mathrm{HC})$, particulate matter $(\mathrm{PM})$, nitrogen oxides (NOx), and sulfur dioxide $\left(\mathrm{SO}_{2}\right)$. Many of the emission factors are based on data from the 1970s and early 1980s (EPA 1998). NONROAD has been updated recently to correct errors and improve emission estimation for these sources (Craig et al. 2003).

The estimation methods found in NONROAD were developed for civilian sources, however, and the emission estimations from this model and other civilian emission estimation methods will not apply to military off-road sources. Military sources differ from civilian sources in the fuels being used, the usage cycles applied to the compression ignition engines, and the engine technology. These differences are well known to affect emissions from diesel engine powered sources (Clark et al. 2002). The primary fuel used by the military during training is JP-8, which is used almost exclusively as a way of reducing fuel distribution problems in the battlefield and during training scenarios. The occasional exception to JP-8 usage is the use of diesel fuels by some Army National Guard and Reserve units during training. In general, JP-8 has a lower boiling temperature and lower density than diesel fuel. JP-8 also contains corrosion inhibitor, static dissipater, and fuel-system icing inhibitor additives. These fuel differences obviously affect emissions, and a few studies indicate some of these effects (Montalvo and Ullmann 1993; Yost et al. 1996). These effects are not accounted for in current emission estimation methods, however. Military equipment usage is also different than usage of civilian counterparts in the trucking, construction, mining, and agricultural industries. Military activity will vary depending on the type of vehicle and equipment and the type of training. Until these usage patterns are studied and documented, the prediction of military engine emissions will be problematic.

Civilian off-road sources include compression ignition engines used in farm, construction, and industrial equipment. Military sources that fall into the off-road category include tactical/combat vehicles and non-vehicular equipment such as generator sets that use diesel engines. Diesel engine emissions include criteria air pollutants such as PM less than 2.5 micrometers in aerodynamic diameter (PM2.5), $\mathrm{PM}$ less than 10 micrometers in aerodynamic diameter (PM10), NOx, $\mathrm{SO}_{2}$, and $\mathrm{CO}$. Diesel exhaust also contains hundreds of gas-phase, semi-volatile, and particulatephase organic compounds. Some of these organic emissions are individually listed by regulators as hazardous air pollutants and the California Air Resources Board (ARB) has listed particulate emissions from diesel-fueled engines as a toxic air con- 
taminant. Diesel engine emissions have been associated with increased cases of lung cancer and noncancer health effects that impair respiratory function (ARB 1998; EPA 2001).

\section{Objectives}

The development of the WP-1338 database described in this report was funded by SERDP to support SERDP project WP-1336, Characterization of Off-Road Diesel Emissions of Criteria Pollutants. The objective of this work was to develop a database of DoD off-road sources and their activity. The WP-1338 database directly supports WP-1336 by serving as input during the selection of off-road equipment that will be tested. This selection is based on equipment inventories, usage levels, fuel consumption, and planned future usage. Detailed tactical equipment information ensures that the equipment tested represents a larger population of the equipment type. Fuel consumption data allow an estimate of engine use that should more closely correspond with engine emissions than do other activity measurements such as vehicle miles driven or hours of operation. The database will also be a component of the base-wide emissions estimation software tool being developed in WP1336. The database can serve as a source of equipment characteristics and activity level information that will be required by the emission estimation methods used in the emission software tool.

Another objective of this work was to develop a database that can function independently from the base-wide emission estimation tool being developed in WP-1336. This objective was achieved by including a simple user interface that allows onscreen filtering and sorting of data and also allows users to generate reports that group and summarize the data.

\section{Approach}

The general approach used during this work included the following activities:

Collect data. Data were gathered for fuels, equipment, engines, and activity/inventory of equipment. The U.S. Army Tank-Automotive Research, Development and Engineering Center (TARDEC) Fuels and Lubricants Research Facility (TFLRF) collected information on fuels, equipment and engines and the U.S. Army Engineer Research and Development Center (ERDC) Construction Engineering Research Laboratory (CERL) collected information on equipment inventory and activity. Chapter 2 discusses the major information sources and some data limitations that were encountered. 
Design and populate database. CERL was responsible for the database design and population. Microsoft ${ }^{\circledR}$ Access was used to create the database and referential integrity is enforced between related tables to maintain data integrity. Chapter 3 discusses overall database design and the methods used to transfer data into each appropriate data table.

Design and develop user interface. CERL created the user interface for the database. The user interface is a separate MS Access database containing forms, queries, reports, and associated Visual Basic ${ }^{\circledR}$ for Applications code. The user interface database contains linkages to the information database described above. Chapter 4 describes the design and use of the user interface.

Analyze data. CERL used the built-in queries and reports of the user interface to perform some general data analyses and to draw some initial conclusions and inferences from the data analysis results. Chapter 5 summarizes these results in tables and discusses the data analyses.

\section{Mode of Technology Transfer}

The primary means of technology transfer has been to provide the database to the investigators working on SERDP project WP-1336. The equipment portion of the database has also been provided to investigators working on SERDP project SI1195, Development of a GIS-Based Complex Terrain Model for Atmospheric Dust Dispersion, as a source of equipment information, such as weight and maximum speed, that is useful in predicting soil-based PM emissions from moving vehicles. The database has also been placed into the permanent shared file library section of the Defense Environmental Network and Information Exchange (DENIX) website, which can be accessed at the following URL:

https://www.denix.osd.mil/denix/DOD/dod.html.

This site is restricted to DENIX users with DoD-level logins and passwords.

This work was published in a peer reviewed conference paper at the annual Air and Waste Management Association 97 ${ }^{\text {th }}$ Annual Conference and Exhibition in Minneapolis, MN (Kemme 2005). The work was presented as part of the Partners in Environmental Technology Technical Symposium and Workshop in Washington, DC, 29 November-1 December 2005. 
This report will also be made accessible through the World Wide Web at the following URLs:

http://docs.serdp-estcp.org/ and

http://www.cecer.army.mil 


\section{Data Collection}

This chapter describes the types of data collected during this project and the sources used to obtain these data. TFLRF researchers collected data for fuels, equipment, and engines, and CERL researchers collected data for equipment activity levels. The different data types were stored in separate spreadsheets in preparation for the consolidation of the data into a database.

\section{Fuels Data}

Fuel information was obtained from fuel surveys completed between 1998 and 2003 and performed first by TRW Petroleum Technologies and later by Northrop Grumman Mission Systems (Dickson 1999-2004). The fuel surveys contain chemical and physical information for aviation turbine fuels (Jet A and JP-8), on-road and offroad diesel fuels (1-D and 2-D), and winter and summer grade gasolines. Tables 2 through 8 contain the most recently documented information about these fuels from the fuel survey reports. Only information that was common to all fuel types was included in the database. Since not all the fuel property information is contained in the database, all the collected fuel information is shown in the following tables. The data in these tables are the starting point for that data that were ultimately included in the database. Some of these fuel property data may be shown to be useful for engine emission estimates if specific fuel characteristics are found to impact emission levels.

Table 2. Summarized data for aviation turbine fuels.

\begin{tabular}{|c|c|c|c|c|c|c|}
\hline Year & \multicolumn{3}{|c|}{2001} & \multicolumn{3}{|c|}{2002} \\
\hline \multicolumn{2}{|l|}{ Number of fuels } & \multicolumn{2}{|l|}{7} & \multicolumn{3}{|c|}{28} \\
\hline \multirow[b]{2}{*}{ Test } & \multicolumn{3}{|c|}{ JP-8 } & \multicolumn{3}{|c|}{ Jet $A$} \\
\hline & Min & Avg & Max & Min & Avg & Max \\
\hline Gravity, ${ }^{\circ} \mathrm{API}$ & 37.3 & 43.1 & 46 & 39.6 & 42.2 & 46.7 \\
\hline \multicolumn{7}{|l|}{ Distillation Temperature: } \\
\hline $10 \%$ recovered, ${ }^{\circ} \mathrm{F}$ & 333 & 355 & 388 & 341 & 369 & 386 \\
\hline $50 \%$ recovered, ${ }^{\circ} \mathrm{F}$ & 375 & 396 & 417 & 368 & 413 & 431 \\
\hline $90 \%$ recovered, ${ }^{\circ} \mathrm{F}$ & 455 & 465 & 474 & 410 & 473 & 510 \\
\hline Freezing point, ${ }^{\circ} \mathrm{F}$ & -81 & -65 & -54 & -74 & -52 & -41 \\
\hline Viscosity, kinematic, $-4^{\circ} \mathrm{F}, \mathrm{cSt}$ & 3.71 & 4.59 & 6.5 & 3.11 & 5.28 & 6.85 \\
\hline Aniline point, ${ }^{\circ} \mathrm{F}$ & 134.1 & NR & 134.1 & 129.7 & 139.7 & 154 \\
\hline Aniline-gravity product No. & 5,941 & NR & 5,941 & 5,136 & 5,904 & 6,405 \\
\hline
\end{tabular}




\begin{tabular}{|c|c|c|c|c|c|c|}
\hline Year & \multicolumn{3}{|c|}{2001} & \multicolumn{3}{|c|}{2002} \\
\hline \multicolumn{2}{|l|}{ Number of fuels } & \multicolumn{2}{|l|}{7} & \multicolumn{3}{|c|}{28} \\
\hline \multirow[b]{2}{*}{ Test } & \multicolumn{3}{|c|}{ JP-8 } & \multicolumn{3}{|c|}{ Jet $A$} \\
\hline & Min & Avg & Max & Min & Avg & Max \\
\hline Acidity, $\mathrm{KOH}, \mathrm{mg} / \mathrm{g}$ & 0.001 & 0.002 & 0.003 & $<0.001$ & 0.012 & 0.03 \\
\hline \multicolumn{7}{|l|}{ Sulfur: } \\
\hline Total, wt.\% & 0.004 & 0.033 & 0.08 & $<0.001$ & 0.05 & 0.205 \\
\hline Mercaptan, wt.\% & $<0.001$ & $<0.001$ & 0.001 & $<0.001$ & 0.001 & 0.002 \\
\hline Naphthalenes, vol.\% & 0.54 & 1.17 & 1.6 & 0.19 & 1.78 & 2.7 \\
\hline Aromatic content, vol. \% & 15 & 19.8 & 22.1 & 12.1 & 18.6 & 24.8 \\
\hline Olefin content, vol.\% & 0.7 & 1.3 & 2.6 & 0 & 1.5 & 3.8 \\
\hline Smoke point, mm & 19 & 20.9 & 25 & 18 & 22.3 & 26 \\
\hline \multicolumn{7}{|l|}{ Gum, mg/100ml: } \\
\hline Existent, at $450^{\circ} \mathrm{F}$ & $<0.1$ & 0.3 & 1 & $<0.1$ & 0.7 & 6.4 \\
\hline Heat of combustion, net, Btu/lb & 18,565 & & 18,565 & 18,616 & 18,477 & 18,605 \\
\hline \multicolumn{7}{|l|}{ Thermal stability: } \\
\hline Pressure drop, $\mathrm{mm} \mathrm{Hg}$ & $<0.1$ & 0.9 & 3 & $<0.1$ & 1.2 & 14 \\
\hline Water separometer index, No. & 94 & 97 & 98 & 90 & 96 & 99 \\
\hline
\end{tabular}

NR - Not Reported; API - American Petroleum Institute gravity degrees; cSt - centistokes; $\mathrm{KOH}$ - potassium hydroxide;

Source: Dickson, April 2003.

Table 3. Summarized national data for 1-D on-highway diesel fuels for 2003.

\begin{tabular}{llll}
\hline Number of fuels & \multicolumn{3}{l}{3} \\
\hline & \multicolumn{3}{l}{ National } \\
\cline { 2 - 4 } Test & Min & Avg & Max \\
\hline Gravity, ${ }^{\circ} \mathrm{API}$ & 41.4 & 43.1 & 44.1 \\
Flash Point, ${ }^{\circ} \mathrm{F}$ & 120 & 138 & 144 \\
Color, Saybolt chromometer & 30 & 30 & 30 \\
Viscosity (kinematic), cSt at $104{ }^{\circ} \mathrm{F}$ & $\mathrm{NR}$ & $\mathrm{NR}$ & $\mathrm{NR}$ \\
Cloud point, $^{\circ} \mathrm{F}$ & $\mathrm{NR}$ & $\mathrm{NR}$ & $\mathrm{NR}$ \\
Pour point, ${ }^{\circ} \mathrm{F}$ & $\mathrm{NR}$ & $\mathrm{NR}$ & $\mathrm{NR}$ \\
Sulfur content, wt. \% & 0.002 & 0.014 & 0.131 \\
Carbon residue on 10\%, wt. \% & 0.02 & 0.078 & 0.12 \\
Ash, wt. \% & $<0.001$ & $<0.001$ & $<0.001$ \\
Cetane number & $\mathrm{NR}$ & $\mathrm{NR}$ & $\mathrm{NR}$ \\
Cetane index & 42.7 & 46.8 & 49.2 \\
Aromatics, vol. \% & 14.2 & 16.5 & 21 \\
Distillation temperature, ${ }^{\circ} \mathrm{F}$ & & & \\
Initial Boiling Point & 285 & 322 & 338 \\
$10 \%$ volume recovered & 366 & 376 & 380 \\
$50 \%$ volume recovered & 417 & 418 & 418 \\
90\% volume recovered & 453 & 462 & 465 \\
End point & 480 & 496 & 500 \\
\hline
\end{tabular}

NR - Not Reported; API - American Petroleum Institute gravity degrees; cSt - centistokes

Source: Dickson 2004. 
Table 4. Summarized 2003 on-highway diesel fuel data for eastern, southern, and central regions.

\begin{tabular}{|c|c|c|c|c|c|c|c|c|c|}
\hline \multirow{2}{*}{$\begin{array}{l}\text { Number of fuels } \\
\text { Test }\end{array}$} & \multicolumn{3}{|c|}{$\begin{array}{c}21 \\
\text { Eastern Region }\end{array}$} & \multicolumn{3}{|c|}{$\begin{array}{c}14 \\
\text { Southern Region }\end{array}$} & \multicolumn{3}{|c|}{$\begin{array}{c}17 \\
\text { Central Region }\end{array}$} \\
\hline & Min & Avg & Max & Min & Avg & Max & Min & Avg & $\operatorname{Max}$ \\
\hline Gravity, ${ }^{\circ} \mathrm{API}$ & 31.5 & 34.5 & 38.5 & 31.4 & 34.5 & 39 & 31.4 & 33.6 & 36 \\
\hline Flash Point, ${ }^{\circ} \mathrm{F}$ & 144 & 1157 & 190 & 153 & 1168 & 179 & 154 & 1168 & 190 \\
\hline Viscosity (kinematic), cSt at $104^{\circ} \mathrm{F}$ & 2.28 & 2.61 & 3.2 & 2.44 & 2.67 & 3.1 & 2.35 & 2.63 & 3.2 \\
\hline Cloud point, ${ }^{\circ} \mathrm{F}$ & -22 & NR & 14 & -24 & NR & 14 & -22 & NR & 10 \\
\hline Pour point, ${ }^{\circ} \mathrm{F}$ & -5 & NR & 10 & -30 & NR & 5 & -30 & NR & 5 \\
\hline Sulfur content, wt. \% & 0.02 & 0.037 & 0.047 & 0.019 & 0.034 & 0.042 & 0.02 & 0.034 & 0.046 \\
\hline Carbon residue on $10 \%$, wt. $\%$ & 0.05 & 0.056 & 0.06 & 0.04 & NR & 0.110 & 0.05 & 0.107 & 1.16 \\
\hline Ash, wt. \% & 0.001 & NR & 0.001 & 0.001 & NR & 0.001 & 0.001 & NR & 0.001 \\
\hline Cetane number & 41.6 & 45.8 & 53.7 & 41.4 & 44.7 & 50.5 & 40.3 & 43 & 46.7 \\
\hline Cetane index & 39.1 & 45 & 53.2 & 42.5 & 45.5 & 54.9 & 39.1 & 43.6 & 49.3 \\
\hline Aromatics, vol. \% & 23.1 & 32.7 & 40.5 & 23.6 & 34.9 & 43.2 & 32.2 & 36.9 & 39.2 \\
\hline \multicolumn{10}{|l|}{ Distillation temperature, ${ }^{\circ} \mathrm{F}$} \\
\hline Initial Boiling Point & 317 & 347 & 397 & 324 & 357 & 398 & 300 & 355 & 398 \\
\hline $10 \%$ volume recovered & 386 & 409 & 465 & 399 & 415 & 442 & 399 & 418 & 465 \\
\hline $50 \%$ volume recovered & 487 & 506 & 538 & 498 & 509 & 525 & 485 & 507 & 538 \\
\hline $90 \%$ volume recovered & 586 & 606 & 627 & 590 & 607 & 628 & 583 & 605 & 634 \\
\hline End point & 638 & 658 & 675 & 635 & 653 & 668 & 635 & 656 & 683 \\
\hline
\end{tabular}

${ }^{1}$ Median value

NR - Not Reported; API - American Petroleum Institute gravity degrees; cSt - centistokes;

Source: Dickson 2004.

Table 5. Summarized 2003 on-highway 2-D diesel fuel data for the nation and the Rocky Mountain and western regions.

\begin{tabular}{|c|c|c|c|c|c|c|c|c|c|}
\hline \multirow[t]{3}{*}{ Number of fuels } & \multicolumn{3}{|c|}{7} & \multicolumn{3}{|c|}{13} & \multicolumn{3}{|c|}{72} \\
\hline & \multicolumn{3}{|c|}{ Rocky Mtn Region } & \multicolumn{3}{|c|}{ Western Region } & \multicolumn{3}{|c|}{ National } \\
\hline & Min & Avg & Max & Min & Avg & Max & Min & Avg & Max \\
\hline Gravity, ${ }^{\circ} \mathrm{API}$ & 32.7 & 34.8 & 36.3 & 32.5 & 36.4 & 41.2 & 31.4 & 34.7 & 41.2 \\
\hline Flash Point, ${ }^{\circ} \mathrm{F}$ & 145 & NR & 145 & 144 & 1149 & 162 & 144 & 1155 & 190 \\
\hline Viscosity (kinematic), cSt at $104^{\circ} \mathrm{F}$ & 2.32 & 2.55 & 2.93 & 2 & 2.6 & 3.43 & 2 & 2.6 & 3.43 \\
\hline Cloud point, ${ }^{\circ} \mathrm{F}$ & -22 & NR & -10 & -22 & NR & 26 & -24 & NR & 26 \\
\hline Pour point, ${ }^{\circ} \mathrm{F}$ & -25 & NR & -25 & -25 & NR & 15 & -30 & NR & 15 \\
\hline Sulfur content, wt. \% & 0.021 & 0.034 & 0.043 & 0.003 & 0.023 & 0.049 & 0.003 & 0.033 & 0.049 \\
\hline Carbon residue on $10 \%$, wt. $\%$ & 0.11 & NR & 0.11 & 0.06 & NR & 0.11 & 0.4 & 0.078 & 0.16 \\
\hline Ash, wt. \% & NR & NR & NR & $<0.001$ & NR & $<0.001$ & $<0.001$ & 0.001 & 0.001 \\
\hline Cetane number & 43.1 & 45.3 & 47.4 & 40.3 & 49.1 & 55.6 & 40.3 & 45.6 & 55.6 \\
\hline Cetane index & 42.8 & 45 & 47.5 & 40 & 47.3 & 56 & 39.1 & 45.2 & 56 \\
\hline Aromatics, vol. \% & 32.7 & 35.1 & 38.2 & 8.9 & 27.8 & 40.1 & 8.9 & 33.4 & 43.2 \\
\hline \multicolumn{10}{|l|}{ Distillation temperature, ${ }^{\circ} \mathrm{F}$} \\
\hline Initial Boiling Point & 328 & 352 & 376 & 302 & 346 & 396 & 300 & 350 & 398 \\
\hline $10 \%$ volume recovered & 377 & 407 & 431 & 374 & 403 & 463 & 374 & 410 & 465 \\
\hline $50 \%$ volume recovered & 484 & 501 & 523 & 437 & 496 & 541 & 437 & 504 & 541 \\
\hline $90 \%$ volume recovered & 585 & 601 & 610 & 585 & 610 & 624 & 583 & 606 & 634 \\
\hline End point & 639 & 654 & 668 & 639 & 648 & 693 & 635 & 659 & 693 \\
\hline
\end{tabular}

${ }^{1}$ Median value

NR - Not Reported; API - American Petroleum Institute gravity degrees; cSt - centistokes

Source: Dickson 2004. 
Table 6. Summarized 2003 off-highway 2-D diesel fuel data.

\begin{tabular}{|c|c|c|c|c|c|c|}
\hline \multirow{3}{*}{$\begin{array}{l}\text { Number of fuels } \\
\text { Test }\end{array}$} & \multicolumn{3}{|c|}{5} & \multicolumn{3}{|c|}{8} \\
\hline & \multicolumn{3}{|c|}{ Southern Region } & \multicolumn{3}{|c|}{ National } \\
\hline & Min & Avg & Max & Min & Avg & Max \\
\hline Gravity, ${ }^{\circ} \mathrm{API}$ & 31.2 & 34.8 & 39 & 31.2 & 34.2 & 39 \\
\hline Flash Point, ${ }^{\circ} \mathrm{F}$ & 142 & 156 & 199 & 142 & 1162 & 199 \\
\hline Viscosity (kinematic), cSt at $104^{\circ} \mathrm{F}$ & 2.1 & 3.05 & 4 & 2.1 & 3.06 & 4 \\
\hline Cloud point, ${ }^{\circ} \mathrm{F}$ & -4 & NR & 22 & -4 & NR & 22 \\
\hline Pour point, ${ }^{\circ} \mathrm{F}$ & -1 & NR & 15 & -10 & NR & 15 \\
\hline Sulfur content, wt. \% & 0.2 & 0.482 & 1 & 0.2 & 0.435 & 1 \\
\hline Carbon residue on $10 \%$, wt. $\%$ & 0.001 & 0.097 & 0.240 & 0.001 & 0.113 & 0.240 \\
\hline Ash, wt. \% & 0.001 & NR & 0.001 & 0.001 & NR & 0.001 \\
\hline Cetane number & NR & NR & NR & NR & NR & NR \\
\hline Cetane index & 40.5 & 48.2 & 51.8 & 40.2 & 46.7 & 51.8 \\
\hline Aromatics, vol. \% & 3 & NR & 3 & 3 & NR & 3 \\
\hline \multicolumn{7}{|l|}{ Distillation temperature, ${ }^{\circ} \mathrm{F}$} \\
\hline Initial Boiling Point & 324 & 368 & 424 & 324 & 371 & 424 \\
\hline $10 \%$ volume recovered & 390 & 425 & 474 & 390 & 430 & 474 \\
\hline $50 \%$ volume recovered & 478 & 514 & 556 & 478 & 515 & 556 \\
\hline $90 \%$ volume recovered & 592 & 612 & 639 & 591 & 613 & 639 \\
\hline End point & 637 & 651 & 671 & 626 & 652 & 688 \\
\hline
\end{tabular}

${ }^{1}$ Median value

NR - Not Reported; API - American Petroleum Institute gravity degrees; cSt - centistokes Source: Dickson, April 2003. 
Table 7. Summarized 2002 data for summer motor gasoline grades (averaged analyses results of $\mathbf{5 5 1}$ motor gasoline samples from service stations throughout the United States).

\begin{tabular}{|c|c|c|c|c|c|c|}
\hline \multirow[b]{2}{*}{ Test } & \multicolumn{3}{|c|}{$\begin{array}{c}(\mathrm{R}+\mathrm{M}) / 2 \\
\text { Below } 88.0\end{array}$} & \multicolumn{3}{|c|}{$\begin{array}{c}(\mathrm{R}+\mathrm{M}) / 2 \\
90.0 \text { and Above }\end{array}$} \\
\hline & Min & Avg & Max & Min & Avg & Max \\
\hline Gravity, ${ }^{\circ} \mathrm{F}$ & 50.3 & 56.5 & 61.8 & 47.8 & 55.7. & 63.6 \\
\hline Sulfur content, wt. \% & $<0.001$ & 0.027 & 0.095 & 0 & 0.007 & 0.039 \\
\hline Gum, mg/100 ml & $<0.1$ & $<0.1$ & 1 & $<0.1$ & $<0.1$ & 1 \\
\hline Saturates, vol. \% & 39.9 & 54.3 & 71.9 & 39.2 & 58.2 & 82.1 \\
\hline Olefins, vol. \% & 0.7 & 12.5 & 25.4 & 0.7 & 5.9 & 15.1 \\
\hline Aromatics, vol. \% & 17 & 31 & 42 & 16.4 & 31.5 & 55.4 \\
\hline Benzene, vol. \% & 0.3 & 1.15 & 3.2 & 0.17 & 0.77 & 2.81 \\
\hline Octane number, Research & 89.9 & 92 & 98.5 & 93.9 & 97.5 & 99.7 \\
\hline Octane number, Motor & 81.3 & 82.6 & 87.8 & 85.6 & 87.5 & 88.9 \\
\hline Antiknock index, $(R+M) / 2$ & 85.7 & 87.3 & 93.2 & 90.2 & 92.5 & 93.7 \\
\hline Vapor pressure, $100^{\circ} \mathrm{F}$, psi & 6.6 & 7.6 & 9 & 6.3 & 7.6 & 9 \\
\hline Vapor-liquid ratio of $20,{ }^{\circ} \mathrm{F}$ & 133 & 147 & 158 & 133 & 151 & 165 \\
\hline \multicolumn{7}{|l|}{ Distillation temperature, ${ }^{\circ} \mathrm{F}$} \\
\hline Initial Boiling Point & NR & 98 & $N R$ & $N R$ & 97 & NR \\
\hline 5\% Evaporated & NR & 120 & NR & $N R$ & 121 & NR \\
\hline $10 \%$ Evaporated & NR & 133 & NR & NR & 137 & NR \\
\hline $20 \%$ Evaporated & NR & 150 & $N R$ & NR & 159 & NR \\
\hline $30 \%$ Evaporated & $N R$ & 168 & $N R$ & $N R$ & 182 & NR \\
\hline $50 \%$ Evaporated & NR & 212 & NR & NR & 224 & NR \\
\hline $70 \%$ Evaporated & NR & 266 & $N R$ & NR & 263 & NR \\
\hline $90 \%$ Evaporated & NR & 337 & NR & NR & 328 & NR \\
\hline 95\% Evaporated & NR & 367 & NR & NR & 357 & NR \\
\hline End point & NR & 415 & $N R$ & NR & 409 & NR \\
\hline Residue, vol. \% & $N R$ & 0.6 & NR & NR & 0.6 & NR \\
\hline Loss, vol. \% & $N R$ & 1.7 & NR & NR & 1.8 & NR \\
\hline \multicolumn{7}{|l|}{ Ethers, vol. \% } \\
\hline MTBE & $<0.1$ & 1 & 13.3 & $<0.1$ & 3.7 & 14.3 \\
\hline TAME & $<0.1$ & 0.1 & 3.6 & $<0.1$ & 0.2 & 3.4 \\
\hline ETBE & $<0.1$ & $<0.1$ & $<0.1$ & $<0.1$ & $<0.1$ & $<0.1$ \\
\hline DIPE & $<0.1$ & $<0.1$ & 0.1 & $<0.1$ & $<0.1$ & 0.2 \\
\hline
\end{tabular}

NR - Not Reported

Source: Dickson, March 2003. 
Table 8. Summarized 2002 and 2003 data for winter motor gasoline grades (averaged analyses results of $\mathbf{3 5 9}$ motor gasoline samples from service stations throughout the United States).

\begin{tabular}{|c|c|c|c|c|c|c|}
\hline \multirow[b]{3}{*}{ Test } & \multicolumn{3}{|c|}{$(R+M) / 2$} & \multicolumn{3}{|c|}{$(R+M) / 2$} \\
\hline & \multicolumn{3}{|c|}{ Below 88.0} & \multicolumn{3}{|c|}{90.0 and Above } \\
\hline & Min & Avg & Max & Min & Avg & Max \\
\hline Gravity, ${ }^{\circ} \mathrm{F}$ & 56.7 & 61.7 & 67.2 & 52.4 & 59.6 & 68.1 \\
\hline Sulfur content, wt. \% & $<0.001$ & 0.029 & 0.079 & $<0.001$ & 0.008 & 0.028 \\
\hline Gum, mg/100 ml & $<0.1$ & 1 & 1 & $<0.1$ & 1 & 1 \\
\hline Saturates,vol. \% & 49.8 & 61.6 & 73.1 & 37.3 & 62.7 & 86.1 \\
\hline Olefins, vol. \% & 1.2 & 11.7 & 22.6 & 1 & 5.5 & 19.2 \\
\hline Aromatics, vol. \% & 18.7 & 26.2 & 32.6 & 11.6 & 29.5 & 39.5 \\
\hline Benzene, vol. \% & 0.46 & 1.1 & 2.51 & 0.14 & 0.71 & 2.88 \\
\hline Octane number, Research & 89 & 91.7 & 93.9 & 92.7 & 97.4 & 100 \\
\hline Octane number, Motor & 80 & 82.7 & 84.8 & 85.9 & 87.8 & 89.7 \\
\hline Antiknock index, $(\mathrm{R}+\mathrm{M}) / 2$ & 84.9 & 87.2 & 89.4 & 90.4 & 92.6 & 94.1 \\
\hline Vapor pressure, $100^{\circ} \mathrm{F}$, psi & 10.2 & 13.1 & 14.7 & 10.2 & 13 & 14.9 \\
\hline Vapor-liquid ratio of $20,{ }^{\circ} \mathrm{F}$ & 108 & 116 & 130 & 110 & 120 & 133 \\
\hline \multicolumn{7}{|l|}{ Distillation temperature, ${ }^{\circ} \mathrm{F}$} \\
\hline Initial Boiling Point & NR & 83 & NR & NR & 83 & NR \\
\hline $5 \%$ Evaporated & NR & 93 & NR & NR & 94 & NR \\
\hline $10 \%$ Evaporated & NR & 105 & NR & NR & 107 & NR \\
\hline $20 \%$ Evaporated & NR & 123 & NR & NR & 130 & NR \\
\hline $30 \%$ Evaporated & NR & 143 & NR & NR & 159 & NR \\
\hline $50 \%$ Evaporated & NR & 192 & NR & NR & 215 & NR \\
\hline $70 \%$ Evaporated & NR & 250 & NR & NR & 258 & NR \\
\hline 90\% Evaporated & NR & 327 & $N R$ & NR & 321 & NR \\
\hline 95\% Evaporated & NR & 358 & NR & NR & 349 & NR \\
\hline End point & NR & 407 & NR & NR & 402 & NR \\
\hline Residue, vol. \% & NR & 0.7 & NR & NR & 0.7 & NR \\
\hline Loss, vol. \% & $N R$ & 2.5 & NR & NR & 2.7 & NR \\
\hline \multicolumn{7}{|l|}{ Ethers, vol. \% } \\
\hline MTBE & $<0.1$ & 4 & 11.2 & $<0.1$ & 2 & 15.8 \\
\hline TAME & $<0.1$ & $<0.1$ & 3 & $<0.1$ & 0.2 & 7.2 \\
\hline ETBE & $<0.1$ & $<0.1$ & 0.2 & $<0.1$ & $<0.1$ & $<0.1$ \\
\hline DIPE & $<0.1$ & $<0.1$ & 0.1 & $<0.1$ & $<0.1$ & 0.6 \\
\hline
\end{tabular}

Source: Dickson, August 2003. 


\section{Equipment Data}

The DoD off-road diesel-powered equipment list is comprised of combat, tactical, and ground support equipment found in the U.S. Army, Marine Corps, Air Force, and Navy. The list contains the following types of equipment:

- wheeled vehicles

- tracked vehicles

- generator sets

- power plants

- construction equipment

- material handling equipment.

The EPA definition of off-road diesel-powered equipment excludes equipment that will be used exclusively in a single location. Equipment used in a single location is categorized as a stationary air pollution source, and off-road diesel-powered equipment includes only mobile sources.

Wheeled vehicles, tracked vehicles, and generator sets make up most of the equipment found in the database. Figure 1 shows examples of wheeled vehicles; Figure 2 , examples of tracked vehicles; Figure 3, examples of generator sets used in the field.

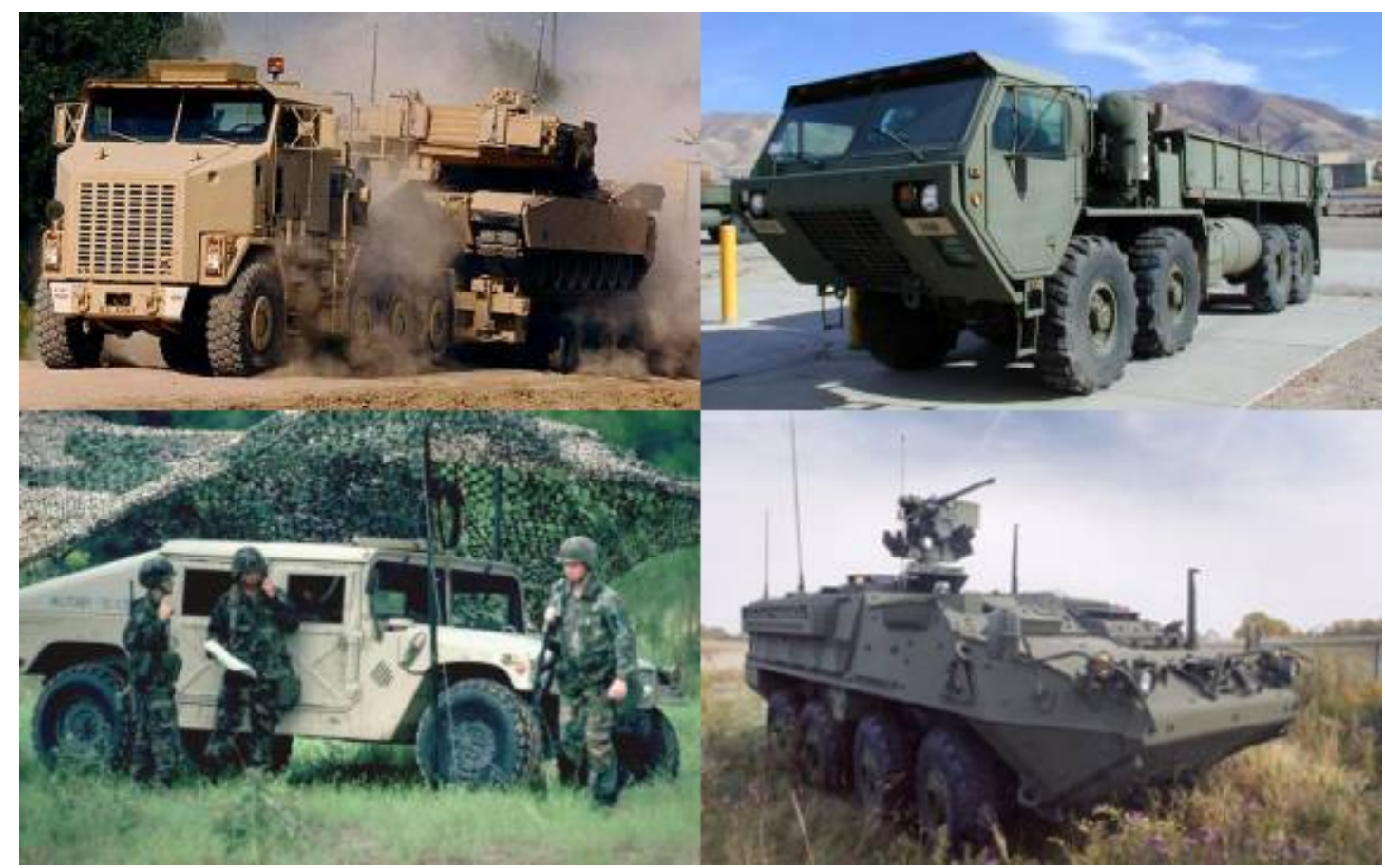

Figure 1. Examples of wheeled vehicles: top left, a heavy equipment transporter (HET); top right, a heavy expanded mobility tactical truck (HEMTT); bottom left, a high mobility multipurpose wheeled vehicle (HMMWV); and bottom right, an interim armored vehicle (IAV) also known as the Stryker. 


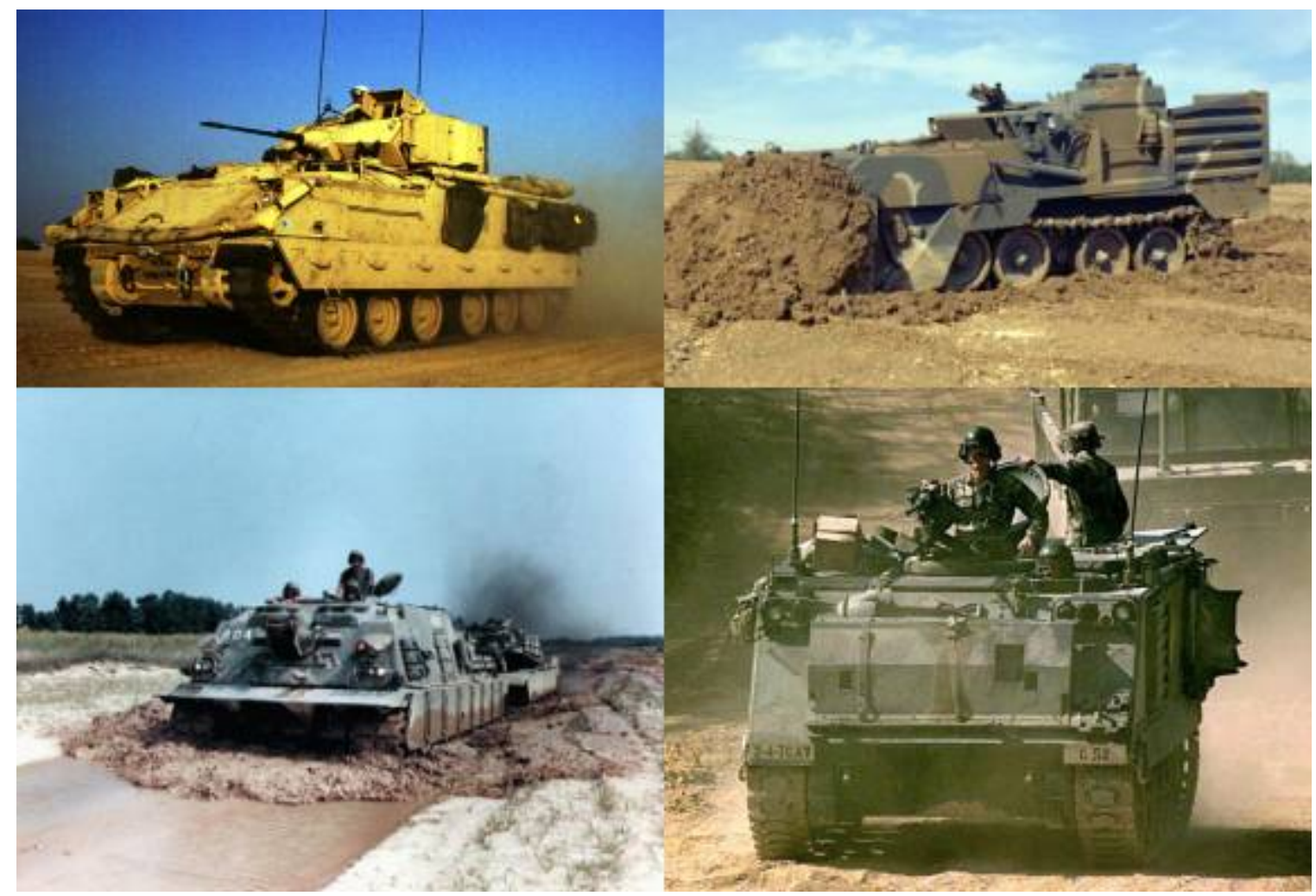

Figure 2. Examples of tracked vehicles: Top left, a Bradley fighting vehicle; top right, an M9 combat earthmover; bottom left, an M88 Hercules recovery vehicle; bottom right, an M113 armored personnel carrier (APC).
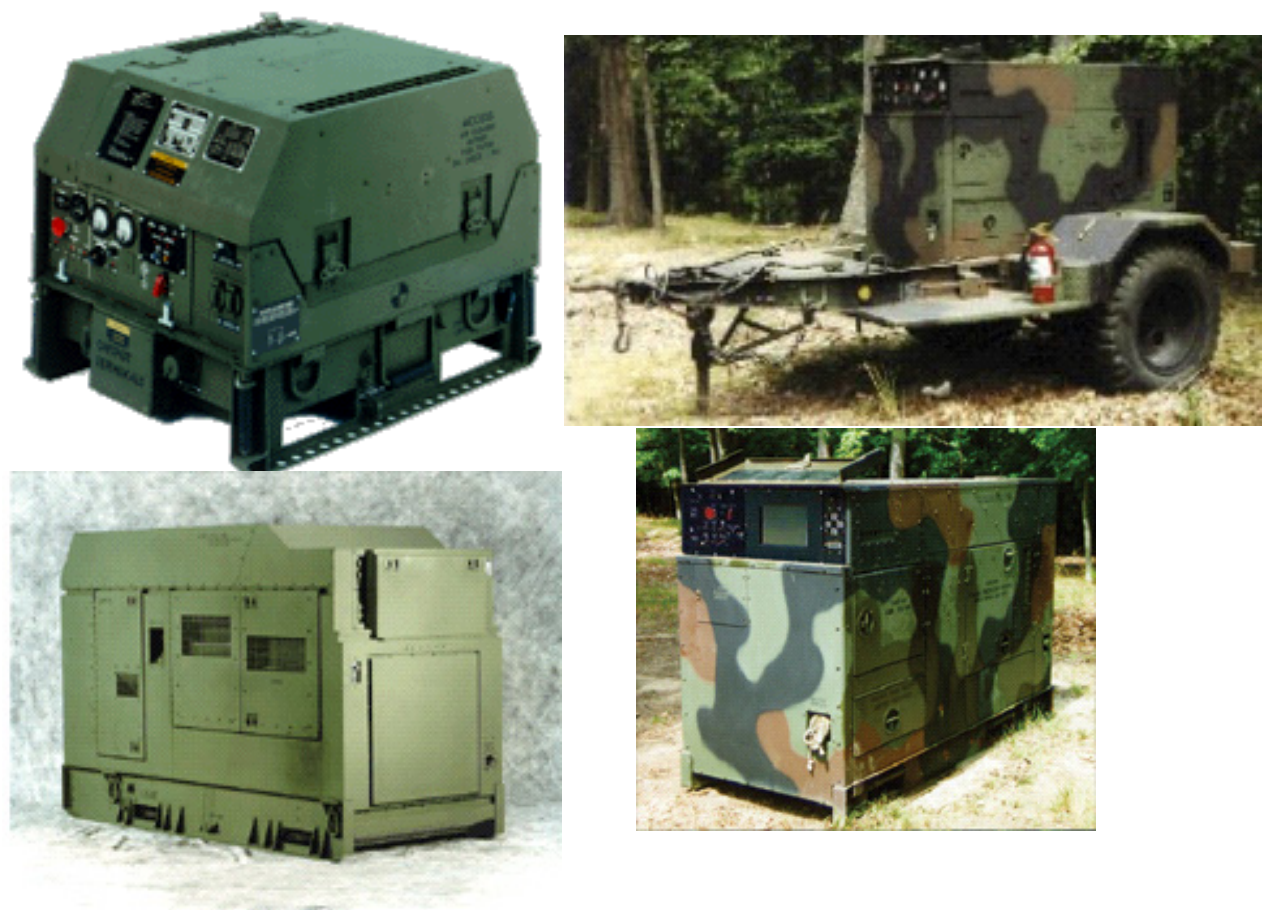

Figure 3. Examples of generator sets: Top left, a 3-kW mobile electric power (MEP), tactical quiet generator (TQG); top right, a 30-kW trailer mounted power unit (PU); bottom left, a 200-kW MEP, TQG; bottom right, a 200-kW MEP TQG. 
The FED LOG Interactive Database was used to gather equipment information for all four services. The FED LOG Interactive Database is a logistics information system that allows the retrieval of data from the Federal Logistics Information System (FLIS) and service specific databases. The FED LOG Interactive Database was primarily used to gather equipment characteristics data, cross-referencing table of authorized material control number (TAMCN) to national stock number for the USMC equipment, and obtaining nomenclature information for USMC and U.S. Air Force (USAF) equipment. The FED LOG Interactive Database is updated routinely and distributed on CDROM or DVD media. The FED LOG Interactive Database used in this work had an effective date of August 2003.

Another common information source for diesel-powered equipment was technical manuals that describe the maintenance and operation of DoD equipment. These technical manuals were downloaded mainly from Internet sites, and the Internet site used most was https://www.logsa.army.mil/etms/online.htm. The technical manuals were found through searches using the line item numbers, national identification numbers (last nine digits of the equipment national stock number), or equipment nomenclature. The technical manuals were the principal source for equipment data such as weight and fuel consumption.

The Army equipment information came from a variety of sources. The starting point was a TFLRF report that included a listing of U.S. Army fuel-consuming mobility and combat support equipment (TARDEC 1996). The equipment list was updated by adding new equipment and deleting old equipment no longer found in the Army's inventory. The following information sources were used to obtain Army equipment data:

- Chapter 2, of Army Supply Bulletin (SB) 700-20, Army Adopted/Other Items Selected for Authorization/List of Reportable Items

- Chapter 3, SB 710-2, Supply Control: Combat Consumption Rates for Ground and Aviation-Type Petroleum Products

- various Army technical manuals for individual pieces of equipment

- the FED LOG Interactive Database.

SB 700-2 and SB 710-2 provide an updated list of diesel-powered Army equipment and the technical manuals for the individual pieces of equipment and the FED LOG Interactive Database provides more detailed information about this equipment. 
The USMC equipment information was collected from the following information sources:

- the Navy Visibility and Management of Operating and Support Cost (VAMOSC) Database (FMB-6 2003)

- Army technical manuals on equipment applicable to the USMC

- the FED LOG Interactive Database.

The VAMOSC management information system collects and reports U.S. Navy and Marine Corps historical weapon system operating and support (O\&S) costs. The cost information includes fuel usage information for USMC ground combat systems. For the equipment database, VAMOSC provides a list of USMC equipment that uses diesel fuel, while technical manuals and the FED LOG Interactive Database provide details about each piece of diesel-powered equipment.

The USAF equipment information was collected from the following information sources:

- equipment database from the Warner Robins Air Logistic Center, Support Equipment and Vehicle Directorate

- Army technical manuals on equipment applicable to the USAF

- the FED LOG Interactive Database.

The initial list of USAF equipment came from a spreadsheet containing a database that included diesel-powered equipment from 2002 (Intellimotive Env. Systems 2002). Intellimotive Environmental Systems (Austin, TX) developed the database for the Warner Robins Air Logistics Center, Support Equipment and Vehicle Directorate. The equipment list was expanded by adding diesel-powered equipment that Army technical manuals identified as USAF equipment. Some of the nonvehicular equipment found in the USAF list would not be classified as an off-road source by regulators at many Air Force facilities because the equipment supports aircraft operations and is always used in the same general location.

The U.S. Navy equipment information was collected from the following sources:

- Construction, Automotive and Specialized Equipment Management Information System (CASEMIS)

- Army technical manuals on equipment applicable to the U.S. Navy

- the FED LOG Interactive Database.

The Navy CASEMIS database was obtained from the Naval Facility Information Technology Center (NITC), Seabee Readiness Support Branch, Port Hueneme, CA. The equipment information in the database was from 2002. The equipment list was expanded by adding diesel-powered equipment that Army technical manuals identified as Navy equipment. Just as with USAF equipment, some of the nonvehicular 
equipment found in the Navy list would not be classified as an off-road source by regulators at many Navy facilities because the equipment supports port operations and is always used at the same general location.

\section{Engines Data}

Engine displacement and horsepower data were collected for each engine with a unique manufacturer and model number. The FED LOG Interactive Database and technical manuals were the primary information sources for the displacement and horsepower data. Also, specific engine manufacturers' (e.g., Detroit Diesel, Cummins, Caterpillar, Onan) Internet sites were consulted to find missing information and as a secondary source for information collected from the FED LOG Interactive Database and technical manuals. In some cases, a specific engine's horsepower output varies with the type of equipment it is powering. When this horsepower variation occurred, the horsepower was averaged so that a single horsepower value was associated with each diesel engine.

\section{Equipment Activity and Inventory}

Equipment activity and inventory information is an important component of estimating emissions from the DoD off-road diesel-powered equipment. The EPA's NOOAD model typically calculates engine emissions based partly on either miles driven or hours of operation. A measure of activity that is more directly related to engine emissions is fuel usage. Fuel usage increases with engine size and horsepower while vehicle miles driven and hours of operation do not. If no measure of equipment activity is available, then equipment inventory numbers may provide some insight as to which locations have the largest level of activity.

The sources of equipment activity and inventory information for this work were the Army Operating and Support Management Information System (OSMIS) and the Navy VAMOSC system. These tools are both examples of systems that support DoD policy requiring the explicit consideration of O\&S costs from the beginning of the acquisition process throughout the operational life of a program to manage and control these costs. The Office of the Secretary of Defense (OSD) VAMOSC program was established as a means of responding to this requirement. Each service provides information for the DoD VAMOSC program. Although the USAF and Navy VAMOSC systems report on ships, aircraft, missiles, torpedoes, ship systems, and aircraft subsystems, they do not report on the diesel-powered support equipment that might be classified as off-road sources. No other national database of Air Force and Navy activity information was found. Therefore, only Army and Marine Corps 
activity information was collected. However, the Army and Marine Corps off-road sources are a large majority of these sources within DoD.

\section{Army Activity Information}

OSMIS is the core of the Army portion of the DoD VAMOSC program. OSMIS, managed by the U.S. Army Cost and Economic Analysis Center (USACEAC), is the Army's source of historical O\&S cost information for over 1,000 major Army weapon/materiel systems deployed in tactical units belonging to the Active Army, National Guard, and Army Reserve.

The OSMIS Relational Database contains the following commodity group of weapon systems:

- Aviation Systems consisting of rotary and fixed wing aircraft

- Combat Systems consisting of tanks and combat vehicles

- Artillery/Missile Systems consisting of artillery weapons, artillery support vehicles, air defense artillery and missiles, surface-to-surface missiles, and detection systems

- Tactical Systems consisting of wheeled vehicles

- Engineer/Construction Systems consisting of engineer, construction, electrical power generation, and floating equipment

- Communications/Electronics Systems consisting of radio receivers, teletypewriters and terminal sets, switches (voices and message), etc., and communications and data processing systems, radar sets, and terminals, etc.

OSMIS captures data from 30 different data sources throughout the Army, with a large majority of the data coming from Logistics Support Activity (LOGSA). OSMIS was developed under guidance that no new data collection efforts be required of the field. All input data must come from an existing Army database. OSMIS is not a real-time system. OSMIS interfaces with the data sources on a monthly, quarterly, or annual basis. Some of the major data sources used by OSMIS are the Logistic Integrated Database (LIF), the Army Master Data File (AMDF), the Continuing Balance System - Extract (CBS-X), and the Provisioning Master Record (PMR).

Ground activity is captured from the Unit Level Logistics System - Ground (ULLSG) as the primary source, and Army Oil Analysis Program (AOAP) data as a secondary source. As units use their vehicle systems, the activity of those systems is tracked. Ground vehicle odometers are checked on a regular basis and this information is also fed through an OSMIS process to generate vehicle mileage across the entire Army fleet of vehicles. For aircraft, flight hours are logged and captured through an OSMIS process. Other systems in the Army are tracked only by the number of systems. For systems that consume fuel, fuel consumption is calculated 
by multiplying the vehicle activity by the fuel consumption rate. Fuel cost is calculated by multiplying fuel consumption by the unit price of the fuel.

A major end item is known by National Item Identification Number (NIIN) from the Army Master Data File (AMDF). Each OSMIS system is also known by Mission Design Series (MDS) and Army Line Item Number (LIN). A list of OSMIS-approved MDS and MDS Names is kept to ensure that the naming of OSMIS-tracked systems and end items is consistent. For example, while a Bradley Fighting Vehicle may be tracked by NIIN or LIN, the MDS is "M2" and the MDS Name is "Bradley." The OSMIS-approved MDS is not necessarily consistent with federally approved naming conventions because the MDS may have to apply to an entire series of systems. For example, the MDS of a specific type of HMMWV is "M966," and the MDS Name is "HMMWV Series." The primary NIIN indicates which major end item is most commonly used within the entire series of major end items that make up an OSMIS system.

The OSMIS system can be accessed at http://www.osmisweb.com/OSMISWeb/. The system requires a user login available to DoD employees or sponsored contractors. Users access data by first selecting predefined data queries. For this work, the "Fuel Consumption" data query was used, which provides inventory, activity (hours of operation or miles driven), and fuel consumption information. The query interrogates the user through a series of screens to define the data set being requested.

Because of the way the query interrogation screens were structured, a separate query needed to be run for each system that used fuel. A list of fuel consuming equipment was generated by running summary reports listing all Army equipment in OSMIS and looking at the activity basis. Systems that showed an activity basis of "MILES" or "HOURS" indicated that the equipment consumed fuel, and queries were run for each of these systems. For Fiscal Year (FY) 2003, OSMIS reported 222 different equipment systems that consumed fuel. The query results included installations both in the Continental United States (CONUS) and outside CONUS (OCONUS). Since this project's focus was on equipment affected by EPA regulations during training operations, results for installations OCONUS were removed from the data set in a later step. Queries were run for FY2001, 2002, and 2003.

After a query request is run in OSMIS, the results are presented in a tabular form on the screen. To save the results, the page must be saved as a web page file with an ".htm" extension. The file can then be imported into an MS Excel spreadsheet. For this work, separate MS Excel spreadsheet files were created for FY2001, 2002, and 2003 and a separate MS Excel sheet was created for each system. Figure 4 shows example OSMIS data imported into a spreadsheet. The image shows only some of the column headings and a small number of equipment systems. 


\begin{tabular}{|c|c|c|c|c|c|c|c|c|c|}
\hline \multicolumn{10}{|c|}{ Myicrosoft Excel - US Army CONUS Tactical Yehicle Fuel Consumption Data (FY 2003).xls } \\
\hline \multicolumn{10}{|c|}{ Eile Edit Wiew Insert Format Iools Data Window Help } \\
\hline \multicolumn{2}{|c|}{ 口乞゙回最 } & 谓佂 & $\Sigma f_{x}$ & $\mathrm{~A} \downarrow \downarrow$ & [a. [?] Verdana & $-10 \cdot$ & \begin{tabular}{lll|l}
$\mathbf{E}$ & $\boldsymbol{I}$ & $\underline{\underline{\underline{\underline{\underline{E}}}}}$
\end{tabular} & 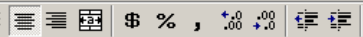 & $-\cdots \underline{A} \cdot$. \\
\hline \multicolumn{10}{|c|}{$\mathrm{A}_{1} \quad-1=\mathrm{MDS}$} \\
\hline & \multirow{2}{*}{ A } & \multirow{2}{*}{ B } & C & D & $E$ & F & G & $\mathrm{H}$ & 1 \\
\hline 1 & & & FY & QTR & \multirow{2}{*}{$\begin{array}{l}\text { INSTALLATION } \\
\text { ADA }\end{array}$} & ACTIVITY BASIS & FUELTYPE & FUEL NOMEN & FUELCOST PI \\
\hline 2 & M927A2 & M939 SERIES & 2003 & 1 & & MILE & JP8 & TURBINE FUEL, AVIATION, KEROSINE & \\
\hline \multicolumn{10}{|c|}{ (2) } \\
\hline \multicolumn{2}{|c|}{ M927A2 } & M939 SERIES & 2003 & 2 & ADA & MILE & JP8 & TURBINE FUEL, AVIATION, KEROSINE & \\
\hline 5 & & & & & & & & & \\
\hline 6 & M927A2 & M939 SERIES & 2003 & 3 & ADA & MILE & JP8 & TURBINE FUEL, AVIATION, KEROSINE & \\
\hline 7 & & & & & & & & & \\
\hline 8 & M927A2 & M939 SERIES & 2003 & 4 & ADA & MILE & JP8 & TURBINE FUEL,AVIATION, KEROSINE & \\
\hline 9 & & & & & & & & & \\
\hline 10 & M927A2 & M939 SERIES & 2003 & 1 & ALBUQUERQUE & MILE & JP8 & TURBINE FUEL,AVIATION, KEROSINE & \\
\hline 11 & & & & & & & & & \\
\hline 12 & M927A2 & M939 SERIES & 2003 & 2 & ALBUQUERQUE & MILE & JP8 & TURBINE FUEL, AVIATION, KEROSINE & \\
\hline 13 & & & & & & & & & \\
\hline 14 & M927A2 & M939 SERIES & 2003 & 3 & ALBUQUERQUE & MILE & JP8 & TURBINE FUEL, AVIATION, KEROSINE & \\
\hline 15 & & & & & & & & & \\
\hline 16 & M927A2 & M939 SERIES & 2003 & 4 & ALBUQUERQUE & MILE & JP8 & TURBINE FUEL, AVIATION, KEROSINE & \\
\hline 17 & & & & & & & & & \\
\hline 18 & M927A2 & M939 SERIES & 2003 & 1. & ATHENS & MILE & JP8 & TURBINE FUEL,AVIATION, KEROSINE & \\
\hline 19 & & & & & & & & & \\
\hline 20 & M927A2 & M939 SERIES & 2003 & 2 & ATHENS & MILE & JP8 & TURBINE FUEL,AVIATION, KEROSINE & \\
\hline 21 & & & & & & & & & \\
\hline 22 & M927A2 & M939 SERIES & 2003 & 3 & ATHENS & MILE & JP8 & TURBINE FUEL, AVIATION, KEROSINE & \\
\hline 23 & & & & & & & & & \\
\hline 24 & M927A2 & M939 SERIES & 2003 & 1. & AVON PARK & MILE & JP8 & TURBINE FUEL, AVIATION, KEROSINE & \\
\hline 25 & & & & & & & & & \\
\hline 26 & M927A2 & M939 SERIES & 2003 & $3 \mathrm{r}$ & AVON PARK & MILE & JP8 & TURBINE FUEL, AVIATION, KEROSINE & \\
\hline 27 & & & & & & & & & \\
\hline 28 & M927A2 & M939 SERIES & 2003 & 4 & AVON PARK & MILE & JP8 & TURBINE FUEL,AVIATION, KEROSINE & \\
\hline 29 & & & & & & & & & \\
\hline 30 & M927A2 & M939 SERIES & 2003 & $1 \mathrm{E}$ & BETHLEHEM & MILE & JP8 & TURBINE FUEL,AVIATION, KEROSINE & \\
\hline 31 & & & & & & & & & \\
\hline 32 & M927A2 & M939 SERIES & 2003 & 10 & CHATTANOOG & MILE & JP8 & TURBINE FUEL, AVIATION, KEROSINE & \\
\hline 33 & & & & & & & & & \\
\hline 34 & M927A2 & M939 SERIES & 2003 & 30 & CHATTANOOG & MILE & JP8 & TURBINE FUEL,AVIATION, KEROSINE & \\
\hline 35 & & & & & & & & & \\
\hline & & & & & & & & & \\
\hline Reac & & & & & & & & & \\
\hline
\end{tabular}

Figure 4. Example of OSMIS data imported into an MS Excel spreadsheet.

The following column headings are included in the OSMIS query results:

- MDS

- MDSNAME

- FY

- QUARTER

- INSTALLATION

- ACTIVITY BASIS

- FUEL TYPE

- FUEL NOMEN

- FUELCOST PER MILE

- ACTIVITY MILES

- FUEL PRICE (Then Years \$)

- TOTAL POL COST (Then Years \$)

- DENSITY

- FUELCOST PER SYSTEM (Then Years \$).

Fuel consumption is not directly reported in the query results, but it can be calculated by dividing the TOTAL POL COST by the FUEL PRICE. 
The query results show activity and inventory information by quarter for each location where the equipment is found. Combining all query runs results in a large amount of data. Each fiscal year contained more than 100,000 unique rows (MDS, FY, INSTALLATION) of information. Part of the reason for this is that OSMIS contains information from many small National Guard and Army Reserve facilities.

One of the query interrogation screens asks for a fuel type selection. However, the fuel type information is a bit misleading in that the activity information does not change with different fuel type selections. Instead, the purpose of the fuel type selection is to set a fuel price for cost calculations. Therefore, the total activity and density levels are always reported regardless of which fuel was selected for the query.

The OSMIS data query results showed a problem with most nonaviation activity results presented in hours. Almost all of the query results showed zero or very trivial amounts of activity. Equipment types that had their activity reported in hours included generator sets, forklifts, cranes, and earth/material handling equipment. Only the density numbers give any indication of potential activity for these sources.

\section{Marine Corps Activity Information}

The Navy VAMOSC system, briefly described in the Equipment section of this chapter, can be accessed at either of these sites: www.navyvamosc.com or http://www.usmcvamosc.com/. Both Internet sites contain a system overview briefing that updates as the system is updated. This report includes information found in the August 2004 FMB-6 briefing.

The Navy VAMOSC system contains information on the following systems:

- Ships Universes

- Aviation Universes

- USMC Ground Equipment

- Weapons

- Personnel Universe.

The system uses 133 different data sources, and the information is updated at least annually with historic information dating back to 1984 .

The USMC ground equipment component of the system was used for the work reported here. This section of the system tracks individual pieces of equipment by their table of authorized material control number (TAMCN). For FY2003 USMC data, the Navy VAMOSC system increased its coverage from 176 to 343 separate TAMCNs. The following data sources are used to update the USMC information: 
- Defense Finance and Accounting Service/Under Secretary of Defense (DFAS/USD) Comptroller

- USMC Logistics Command (LOGCOM)

- Navy Petroleum Office

- Asset Tracking, Logistics and Supply System (ATLASS II+) Program Office

- USMC Systems Command (SYSCOM).

The Navy VAMOSC system allows users to create custom queries from data stored in one of eleven data "universes." For this work, the "USMC Ground Equipment" universe was used. Two separate queries had to be run. The first query contained equipment activity and fuel usage information for all the ground equipment. Figure 5 shows the first page of results from this query. The query contains columns for the fiscal year, TAMCN, TAMCN description, average activity per item, the units for the activity (hours or miles), and the total fuel cost. As Figure 5 shows, not all of the reported equipment uses fuel, with only the very last item on the screen showing a fuel usage. Figure 5 also demonstrates that this query did not report the activity or fuel consumption data by location but provided a summary for all locations. For this reason, a separate query was run to show the inventory of equipment at different locations. Figure 6 shows the first page of results for this new query. The query contains columns for the fiscal year, TAMCN, TAMCN description, location, and inventory. Both of these queries were run for FY2001, 2002, and 2003, and the download feature of the Navy VAMOSC system was used to save the query results into two MS Excel spreadsheet files.

Since a single query could not be designed that would generate activity results by location, the two query results were combined into a single spreadsheet to apportion the summary activity information for individual locations. The first step was the elimination of all equipment that did not report any activity. For activity information, the spreadsheet calculated activity at individual locations by multiplying the average activity per item by the number of items found at a location. For fuel consumption information, the spreadsheet first calculated the total gallons of fuel by dividing the total Petroleum, Oils, and Lubricants (POL) cost by the price of JP-8 fuel for the year the activity was recorded. The POL costs were obtained from the Navy VAMOSC, USMC Ground Equipment User Manual (IBM 2004). The usage for each location was then apportioned by the number of items at a location divided by the total number of items throughout the USMC. The Navy VAMOSC system did not exhibit the same problem as the OSMIS system with regard to reporting activity for equipment when the activity is measured in hours. 


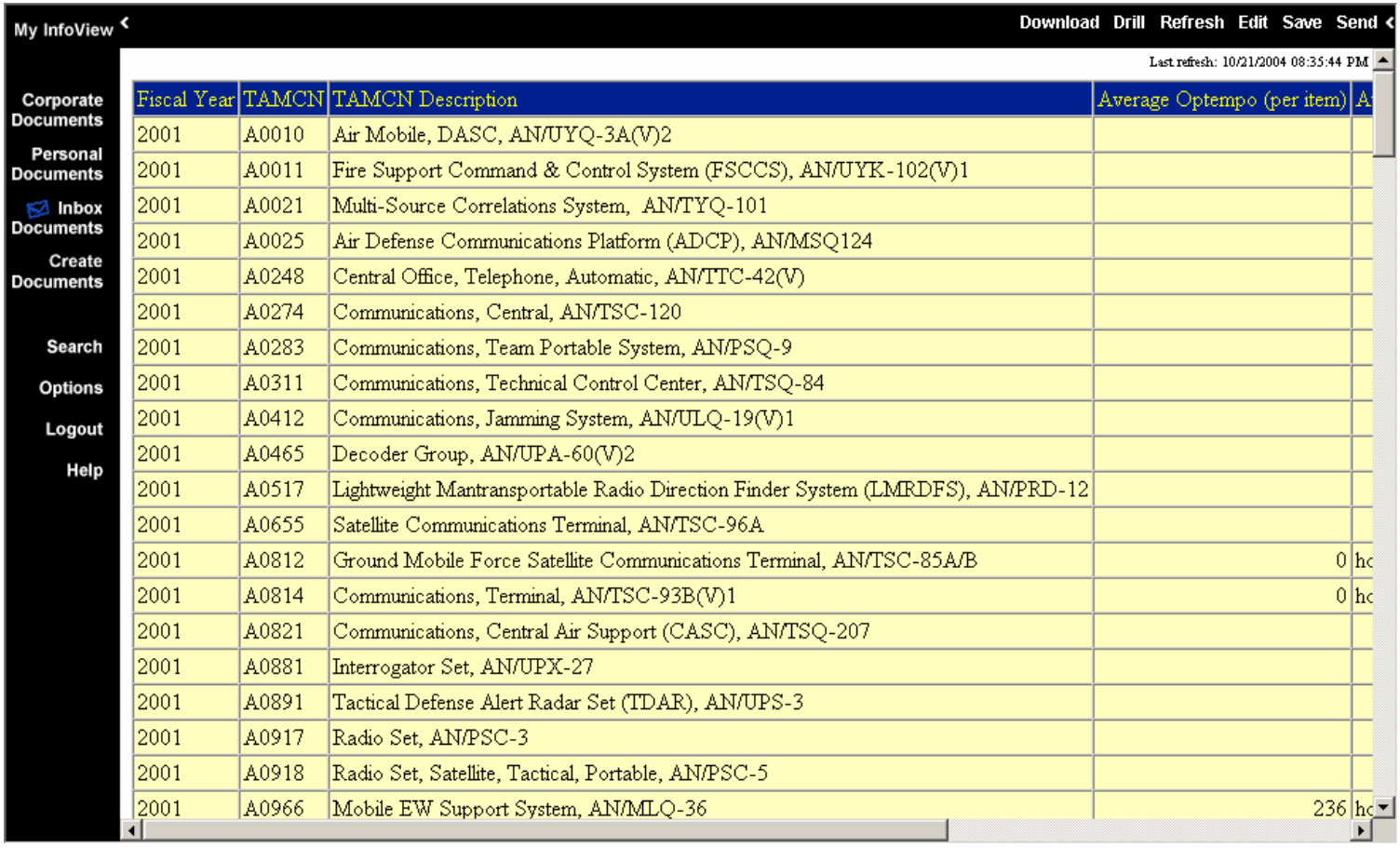

Figure 5. First page of query results showing activity and fuel usage information from the Navy VAMOSC system. 


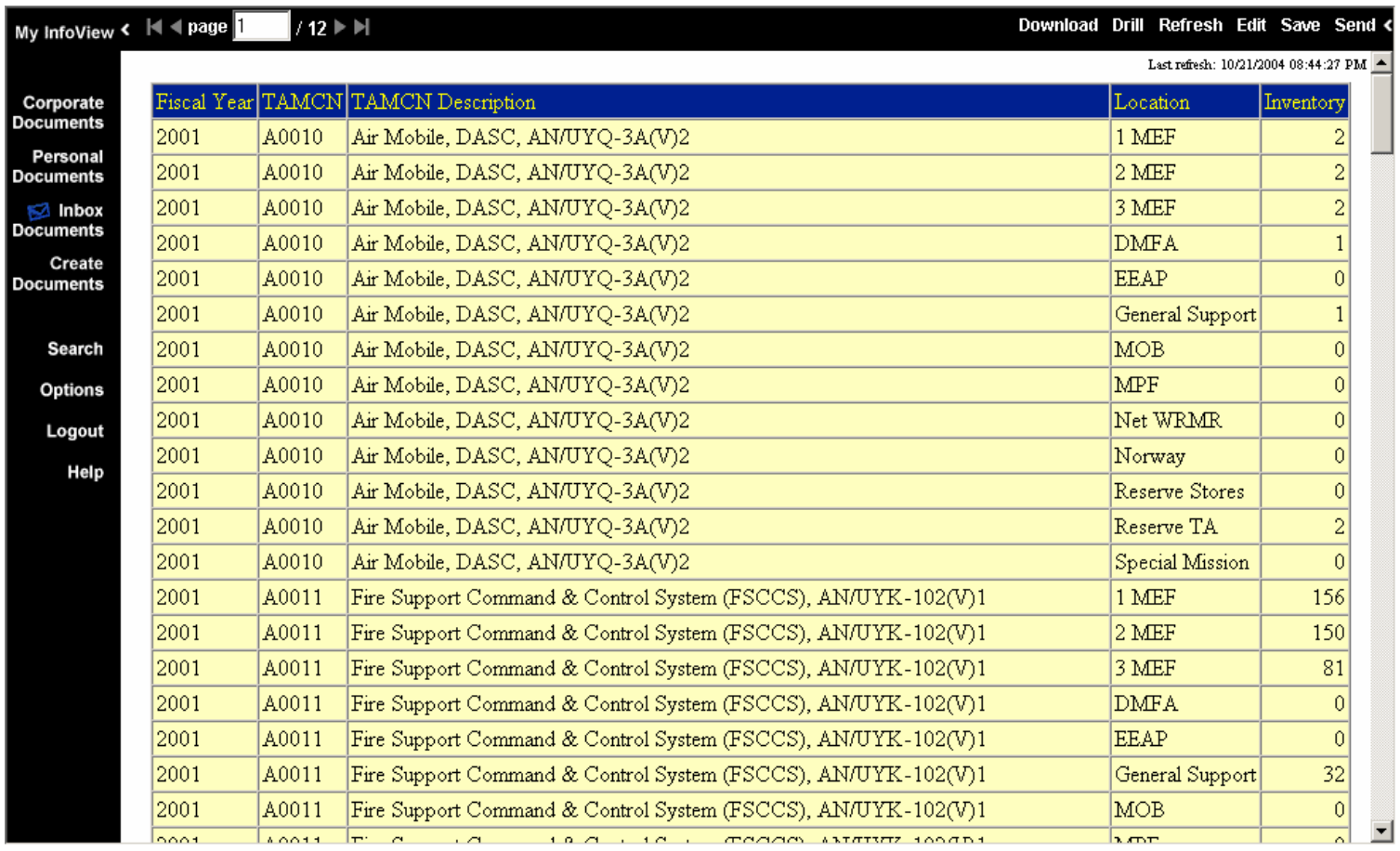

Figure 6. First page of query results showing inventory information from the Navy VAMOSC system.

\section{Summary}

For the most part, the data collection objectives of this project were met. Data were collected for fuels, equipment, engines, and equipment activity levels. Equipment and engine information came from many different sources, but the data were consolidated and entered into engine and equipment spreadsheets that contain information from all the services. This information should prove useful to the WP-1336 research group as they develop an emission estimation tool. Equipment activity level information was successfully gathered for the Army and USMC but not for the Air Force and Navy who do not centrally account for the off-road diesel equipment that support aircraft and ships. Therefore, the WP-1336 research group cannot use the activity information to prioritize Air Force and Navy off-road emission sources. However, the inventory of off-road diesel-powered equipment owned by the Air Force and Navy is much smaller than the Army and USMC inventory since their mission is more oriented towards off-road training. The Army and USMC activity data should prove very useful in determining the diesel-powered off-road equipment used most often by these services. 


\section{Database Design and Population}

As mentioned in the Introduction, two MS Access databases were developed during this project. This chapter describes the database that stores the information that was collected, and Chapter 4 describes the database that provides a user interface for displaying data and viewing reports on the collected information. Researchers used MS Access 2000 for this work, and earlier versions of Access will not be able to read the database files.

Database information is kept in tables designed to store related data. Tables contain records that are similar to rows in a spreadsheet and fields that are like columns in a spreadsheet. The fields and field names describe the types of data contained in a table and each record stores an individual instance of this data. A table also has a primary key that defines what makes each record unique. The primary key is composed of one or more fields in the table, and the data in the primary key fields are unique for every record in the table.

\section{Overall Structure}

The following tables are included in the database:

- Installations

- Fuels

- Equipment

- Engines

- Equipment Activity and Inventory.

Figure 7 is the MS Access relationships diagram that shows the overall design of the database. The diagram shows all the database tables and their relationships with each other. Multiple tables are used in a database to avoid storage of repetitive information that is common to many records in another table. Tables are linked to each other using fields that occur in both tables. For example, the Engines table is linked to the Equipment table using the fields "Engine_Manufacturer" and "Model_Number." The "1" symbol in the diagram indicates the table that contains a single record that is related to many records in the other table of the relationship. 


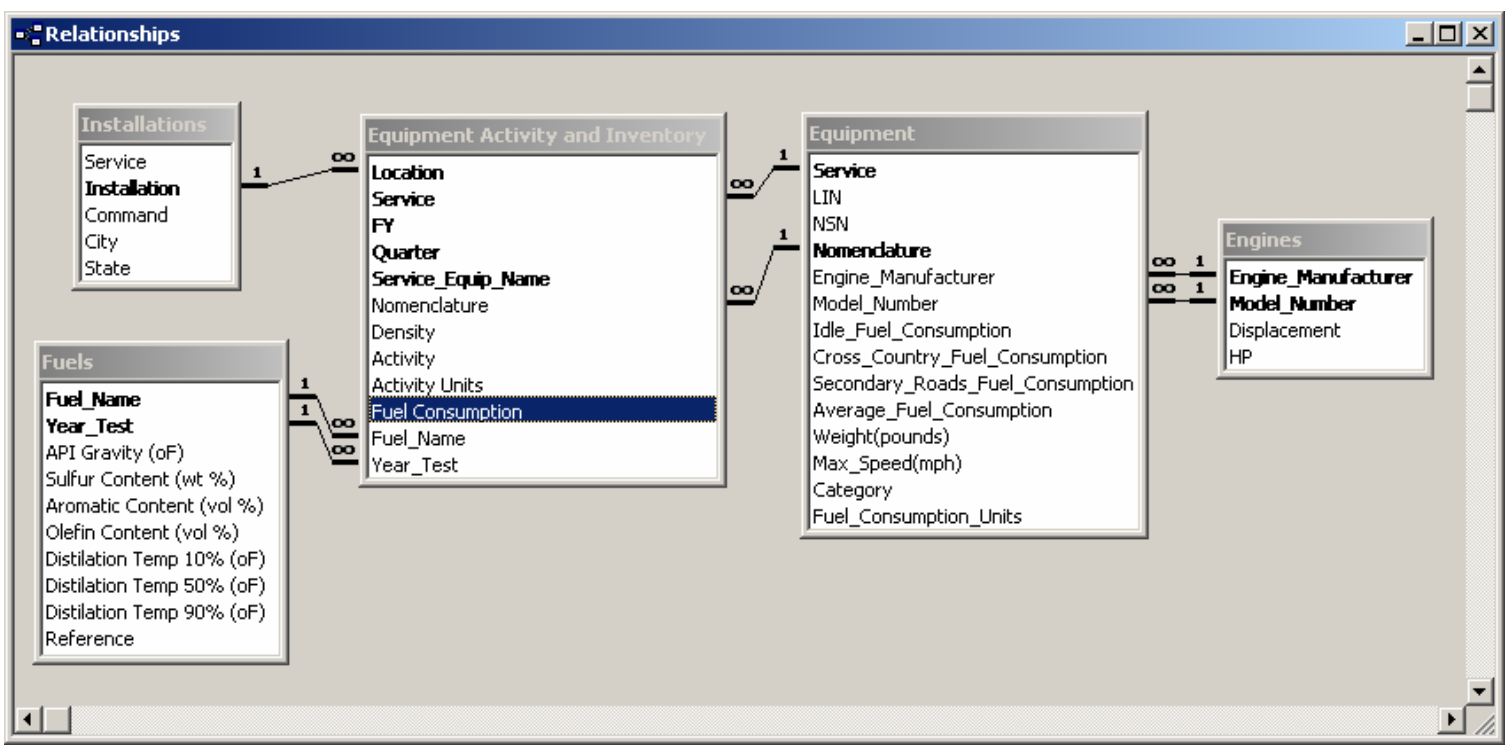

Figure 7. Overall database design.

For all the relationships in the database, referential integrity was enforced and the cascade update feature was activated. Enforcing referential integrity ensures that data remain consistent within the database. Activating the cascade update feature will automatically change the data on the many side of a one-to-many relationship when a datum is changed in one of the linked fields in the table on the one side of the relationship. The cascade delete feature was activated between the Equipment Activity and Inventory table and the Equipment table and between the Equipment table and the Engines table. In this way, if any piece of equipment is deleted, then the associated records in the Equipment Activity and Inventory table are also deleted. If an Engine table record is deleted, then the associated records in the Equipment table are deleted and the Equipment deletions will again cause deletions of associated records in the Equipment Activity and Inventory table.

\section{Fuels Data}

The Fuels table in the database includes a subset of the data found in the fuels spreadsheet tables shown in Chapter 2. The fields included in the table were selected because they contain information that is common to all the fuels. Figure 8 shows the Fuels table design screen that lists the field names and data types. When a field contains a numeric property of the fuel, the field name includes the units of that property enclosed in parenthesis at the end of the field name. The fields "Fuel_Name" and "Year_Test" are both included in the primary key because different fuel testing years are included in the table. The "Reference" field contains citations for the fuel testing reports used as data sources for each record. 


\begin{tabular}{|c|c|c|c|}
\hline \multicolumn{2}{|c|}{ 㖆 Fuels : Table } & \multicolumn{2}{|c|}{ - $\square$} \\
\hline & Field Name & Data Type & 4 \\
\hline ? & Fuel_Name & Text & \\
\hline ? & Year_Test & Text & \\
\hline & API Gravity (oF) & Number & \\
\hline & Sulfur Content (wt \%) & Number & \\
\hline & Aromatic Content (vol \%) & Number & \\
\hline & Olefin Content (vol \%) & Number & \\
\hline & Distilation Temp $10 \%$ (oF) & Number & \\
\hline & Distilation Temp 50\% (oF) & Number & \\
\hline & Distilation Temp $90 \%$ (oF) & Number & \\
\hline & Reference & Memo & \\
\hline & & & $\nabla$ \\
\hline
\end{tabular}

Figure 8. Fuels table design screen.

Figure 9 contains some of the data from the Fuels table. The figure shows all of the records in the table but not all of the fields. Figure 9 illustrates that some fuel types have more than one record because multiple testing years are included in the data set.

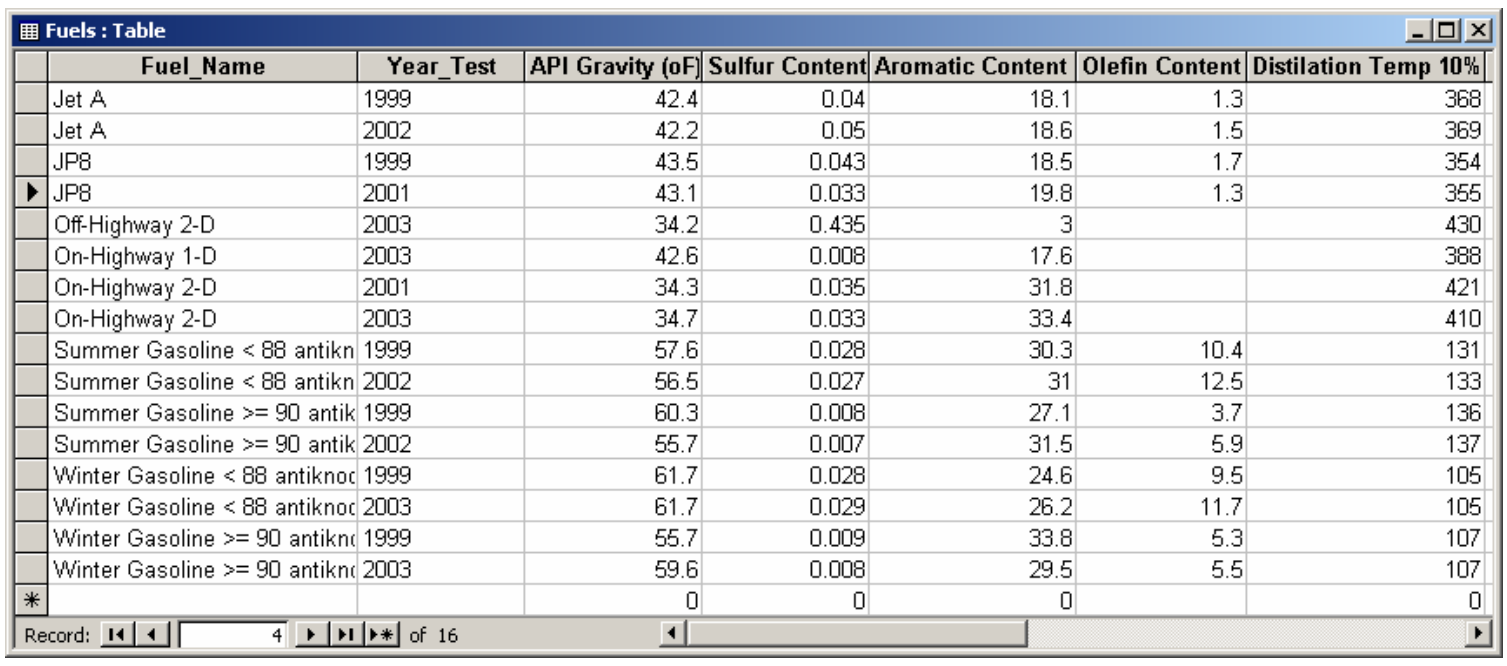

Figure 9. Data from the Fuels table.

\section{Equipment Data}

The Equipment table in the database contains a list of off-road diesel-powered equipment used by DoD and properties and attributes of this equipment. The fields included in the table either help identify the equipment or contain properties that may be important in predicting engine emissions. Figure 10 shows the Equipment table design screen that lists the field names and data types. When a field contains a numeric property of the fuel, the field name includes the units of that property enclosed in parenthesis at the end of the field name. The exceptions to this are the fields containing fuel consumption information. In this case, the field 
"Fuel_Consumption_Units" contains the fuel consumption units that were either $\mathrm{km} / \mathrm{hr}$ for vehicular equipment or gal/hr for nonvehicular equipment. The fields "Service" and "Nomenclature" both are included in the primary key because the same equipment with the same Nomenclature may be shared by different services. The field "LIN" contains a service-specific identification number while the field "NSN" contains the service independent national stock number. A few records are missing the NSN, LIN, or both the NSN and LIN.

\begin{tabular}{|c|c|c|c|}
\hline \multicolumn{2}{|c|}{ 柬 Equipment : Table } & \multicolumn{2}{|c|}{$-\square|x|$} \\
\hline & Field Name & Data Type & $\Delta$ \\
\hline i & Service & Text & \\
\hline & LIN & Text & \\
\hline & NSN & Text & \\
\hline ? & Nomenclature & Text & \\
\hline & Engine_Manufacturer & Text & \\
\hline & Model_Number & Text & \\
\hline & Idle_Fuel_Consumption & Number & \\
\hline & Cross_Country_Fuel_Consumption & Number & \\
\hline & Secondary_Roads_Fuel_Consumption & Number & \\
\hline & Average_Fuel_Consumption & Number & \\
\hline & Weight(pounds) & Number & \\
\hline & Max_Speed(mph) & Text & \\
\hline & Fuel_Consumption_Units & Text & \\
\hline
\end{tabular}

Figure 10. Equipment table design screen.

Figure 11 contains a snapshot of data from the Equipment table. The figure shows records containing data for HEMTT and cargo trucks used by the Army. Figure 11 shows that there are 1,103 records in the Equipment table, which includes equipment with a wide range of introduction dates since the DoD has consistently developed new versions of equipment over time but still uses equipment that was introduced decades earlier. 


\begin{tabular}{|c|c|c|c|c|c|c|}
\hline \multicolumn{4}{|c|}{ 典 Equipment : Table } & \multicolumn{3}{|c|}{$-[ㅁ ㅣ$} \\
\hline \begin{tabular}{|l|l|} 
& Service \\
\end{tabular} & LIN & NSN & Nomenclature & Engine_Manufacturer & Model_Number & $\Delta$ \\
\hline USA & $\times 39187$ & 2320000508927 & TRUCK BOLSTER 5TON WW M815 & CUMMINS ENGINE & NHC 250 & \\
\hline USA & T59278 & 2320010996426 & TRUCK CARGO 10TON HEMTT M977 & DETROIT DIESEL & 8V92TA & \\
\hline USA & T59278 & 2320014933779 & TRUCK CARGO 10TON HEMTT M977A2 & DETROIT DIESEL & 8V92TA DDEC IV & \\
\hline USA & T59278 & 2320014933785 & TRUCK CARGO 10TON HEMTT M977A2R1 & DETROIT DIESEL & 8V92TA DDEC IV & \\
\hline USA & T39586 & 2320011007673 & TRUCK CARGO 10TON HEMTT M985 & DETROIT DIESEL & 8V92TA & \\
\hline USA & T39586 & 2320014928201 & TRUCK CARGO 10TON HEMTT M985A2 & DETROIT DIESEL & 8V92TA DDEC IV & \\
\hline USA & T39586 & 2320014933789 & TRUCK CARGO 10TON HEMTT M985A2R1 & DETROIT DIESEL & 8V92TA DDEC IV & \\
\hline USA & T41721 & 2320011947032 & TRUCK CARGO 10TON HEMTT M985E1 & DETROIT DIESEL & 8V92TA & \\
\hline USA & T41721 & 2320014933790 & TRUCK CARGO 10TON HEMTT M985E1A2 & DETROIT DIESEL & 8V92TA DDEC IV & \\
\hline USA & T41721 & 2320014933792 & TRUCK CARGO 10TON HEMTT M985E1A2R1 & DETROIT DIESEL & 8V92TA DDEC IV & \\
\hline USA & T39518 & 2320010970260 & TRUCK CARGO 10TON HEMTT WW M977 & DETROIT DIESEL & 8\92TA & \\
\hline USA & T39518 & 2320014933774 & TRUCK CARGO 10TON HEMTT WW M977A2 & DETROIT DIESEL & 8V92TA DDEC IV & \\
\hline USA & T39518 & 2320014933782 & TRUCK CARGO 10TON HEMTT WW M977A2R1 & DETROIT DIESEL & 8V92TA DDEC IV & \\
\hline USA & T39654 & 2320010970261 & TRUCK CARGO 10TON HEMTT WW M985 & DETROIT DIESEL & 8V92TA & \\
\hline USA & T39654 & 2320014928214 & TRUCK CARGO 10TON HEMTT WW M985A2 & DETROIT DIESEL & 8V92TA DDEC IV & \\
\hline USA & T39654 & 2320014933787 & TRUCK CARGO 10TON HEMTT WW M985A2R1 & DETROIT DIESEL & 8V92TA DDEC IV & \\
\hline USA & $\times 41790$ & 2320007400493 & TRUCK CARGO 10TON WW M125A1 & CUMMINS ENGINE & V8-300 & \\
\hline USA & $\times 40077$ & 2320009260873 & TRUCK CARGO 21/2TON D/S M35A2C & CONTINENTAL & LD465-1 & \\
\hline USA & $\times 40077$ & 2320013832050 & TRUCK CARGO 21/2TON D/S M35A3C & CATERPILLAR & 3116 ATAAC & \\
\hline USA & $\times 40214$ & 2320009260875 & TRUCK CARGO 21/2TON D/S WW M35A2C & CONTINENTAL & LD465-1 & \\
\hline USA & $\times 40214$ & 2320013832049 & TRUCK CARGO 21/2TON D/S WW M35A3C & CATERPILLAR & 3116 ATAAC & \\
\hline USA & $\times 40283$ & 2320013832048 & TRUCK CARGO 21/2TON LWB M36A3 & CATERPILLAR & 3116 ATAAC & \\
\hline USA & $\times 40420$ & 2320013832046 & TRUCK CARGO 21/2TON LWB WW M36A3 & CATERPILLAR & 3116 ATAAC & \\
\hline USA & $\times 40009$ & 2320005425633 & TRUCK CARGO 21/2TON M35A1 & CONTINENTAL & LDS465-1 & \\
\hline USA & $\times 40009$ & 2320000771616 & TRUCK CARGO 21/2TON M35A2 & CONTINENTAL & LDS465-1 & \\
\hline USA & $\times 40009$ & 2320013832047 & TRUCK CARGO 21/2TON M35A3 & CATERPILLAR & 3116 ATAAC & \\
\hline USA & $\times 40146$ & 2320005425634 & TRUCK CARGO 21/2TON WW M35A1 & CONTINENTAL & LDS465-1 & \\
\hline USA & $\times 40146$ & 2320000771617 & TRUCK CARGO 21/2TON WW M35A2 & CONTINENTAL & LD465-1 & \\
\hline USA & $\times 40146$ & 2320013833850 & TRUCK CARGO 21/2TON WW M35A3 & CATERPILLAR & 3116 ATAAC & \\
\hline USA & $\times 40283$ & 2320000771618 & TRUCK CARGO 21/2TON XLWB M36A2 & CONTINENTAL & LD465-1 & $\rightarrow$ \\
\hline Record: $\mid \mathbf{1 4}$ & $4 \longdiv { \square }$ & $1 \mapsto|\mapsto| \bullet \mid$ & of 1103 & & & \\
\hline
\end{tabular}

Figure 11. Data from the Equipment table.

When the equipment data were collected, it was discovered that some equipment had the same Nomenclature names but different NSNs. It was decided to enter all of these equipment data in case users should want to search for equipment by its NSN. These records are distinguished from one another in the table by adding sequential numbers, starting with one, enclosed in parenthesis at the end of the Nomenclature name. For example, the table includes records with the Nomenclature names "GEN ST DED 10KW 400HZ TQ PU799(1)" and "GEN ST DED 10KW 400HZ TQ PU799(2)" with NSNs of "6115013134283" and "6115014133819."

Some of the records for tracked vehicles in the Equipment table contain fuel consumption rates specified for idle, cross country, and secondary road conditions. In these cases, an average fuel consumption rate was not published and the average fuel consumption value in the table was calculated by averaging the three available fuel consumption values from the Equipment table. 


\section{Engine Data}

The Engines table in the database contains a list of engines used in DoD off-road diesel-powered equipment. Engine manufacturers and model numbers identify each of the engines. The engine displacements and horsepower are also recorded in the Engine table. Figure 12 shows the Engines table design screen that lists the field names and data types. The engine displacement is measured in cubic inches. The fields "Engine_Manufacturer" and "Model_Number" both are included in the primary key because the same manufacturer often makes several diesel engines used in DoD equipment.

\begin{tabular}{|c|c|c|c|}
\hline \multicolumn{2}{|c|}{ 囲 Engines : Table } & \multicolumn{2}{|c|}{ - $|\square|$} \\
\hline & Field Name & Data Type & $\Delta$ \\
\hline i & Engine_Manufacturer & Text & \\
\hline i & Model_Number & Text & \\
\hline & Displacement & Number & \\
\hline & $\mathrm{HP}$ & Number & $\nabla$ \\
\hline
\end{tabular}

Figure 12. Engines table design screen.

Figure 13 contains a snapshot of data from the Engines table. The figure shows records containing data for engines manufactured by Continental and Cummins Engine. The figure also shows that there are 175 records in the Engines table. Although not shown in Figure 13, a few records are missing the displacement and horsepower information. As mentioned in Chapter 2, some of the horsepower fields contain averages of horsepower values varied by different equipment types that used the same engine. 


\begin{tabular}{|c|c|c|c|c|c|}
\hline \multicolumn{3}{|l|}{ 囲 Engines : Table } & \multicolumn{3}{|c|}{$-|\square| x$} \\
\hline " Engine_Manufacturer & |Model_Number & Displacement & HP & & $\Delta$ \\
\hline CONTINENTAL & AVDS1790-2A & 1790 & & 83 & \\
\hline CONTINENTAL & AVDS1790-2A, D, D & 1790 & & 83 & \\
\hline CONTINENTAL & AVDS1790-2C & 1790 & & 83 & \\
\hline CONTINENTAL & AVDS1790-2D & 1790 & & 83 & \\
\hline CONTINENTAL & AVDS1790-2DA & 1790 & & 83 & \\
\hline CONTINENTAL & AVDS1790-2DR & 1790 & & 83 & \\
\hline CONTINENTAL & LD465-1 & 478 & & 60 & \\
\hline CONTINENTAL & LDS465-1 & 478 & & 60 & \\
\hline CONTINENTAL & TMD27 & 299 & & 101 & \\
\hline CUMMINS ENGINE & $4 B 3.9$ & 239 & & 74 & \\
\hline CUMMINS ENGINE & 6BT5.9 & 359 & & 152 & \\
\hline CUMMINS ENGINE & 6BT5.9-C & 359 & & 152 & \\
\hline CUMMINS ENGINE & 6СТАВ.3 & 506 & & 240 & \\
\hline CUMMINS ENGINE & C180 & 300 & & 130 & \\
\hline CUMMINS ENGINE & $J N-6-I$ & 401 & & 101 & \\
\hline CUMMINS ENGINE & KT1150 & 1150 & & 180 & \\
\hline CUMMINS ENGINE & KTA2300G & 2300 & & 35 & \\
\hline CUMMINS ENGINE & N855/235 & 855 & & 35 & \\
\hline CUMMINS ENGINE & $\mathrm{NHC} 250$ & 854 & & 50 & \\
\hline CUMMINS ENGINE & NT-380-1 & 1015 & & 335 & \\
\hline CUMMINS ENGINE & NTC 400 & 855 & & 400 & \\
\hline CUMMINS ENGINE & NTTA-855-P450 & 855 & & 150 & \\
\hline CUMMINS ENGINE & QSM 11 & 661 & & 400 & \\
\hline CUMMINS ENGINE & V8 2652380 & 785 & & 265 & \\
\hline CUMMINS ENGINE & V8-300 & 785 & & 300 & \\
\hline CUMMINS ENGINE & V903c & 903 & & 295 & \\
\hline CUMMINS ENGINE & VT400 & 854 & & 400 & \\
\hline CUMMINS ENGINE & VTA28G1 & 1710 & & 50 & \\
\hline CUMMINS ENGINE & VTA-903T & 903 & & 600 & \\
\hline CUMMINS ENGINE & VTA903-T525 & 903 & & 525 & $\nabla$ \\
\hline 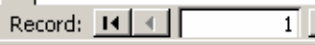 & •|口|P* of 175 & & & & \\
\hline
\end{tabular}

Figure 13. Data from the Engines table.

\section{Equipment Activity and Inventory Data}

The Equipment Activity and Inventory table contains activity information for Army and USMC diesel-powered off-road equipment. The fields describe inventory, activity, and fuel consumption information for equipment used at specific locations over either a quarter (Army) or year (USMC). Figure 14 shows the MS Access Equipment Activity and Inventory table design screen that lists the field names and data types. "Fuel_Consumption" is always reported in gallons, and activity is either reported in miles traveled or hours of operation, with the appropriate units shown in the "Activity Units" field. Since the table records information from varying services, equipment types, and time periods, the primary key is a combination of the "Location," "Service," "FY," "Quarter," and "Service_Equip_Name." 


\begin{tabular}{|c|c|c|c|}
\hline \multicolumn{4}{|c|}{ 囲 Equipment Activity and Inventory : Table $-|\square| x \mid$} \\
\hline & Field Name & Data Type & $\Delta$ \\
\hline ? & Location & Text & \\
\hline 8 & Service & Text & \\
\hline P & FY & Text & \\
\hline 8 & Quarter & Text & \\
\hline ? & Service_Equip_Name & Text & \\
\hline & Nomenclature & Text & \\
\hline & Density & Number & \\
\hline & Activity & Number & \\
\hline & Activity Units & Text & \\
\hline & Fuel Consumption & Number & \\
\hline & Fuel_Name & Text & \\
\hline & Year_Test & Text & - \\
\hline
\end{tabular}

Figure 14. Equipment Activity and Inventory table design screen.

Figure 15 contains a small sample of data from the Equipment Activity and Inventory table. The figure shows usage and inventory data for a variety of Army equipment used at Fort Lewis, WA, during the first quarter of FY2002. The records show a wide variation of density and activity. The first record contains the largest inventory value at Fort Lewis, and the second record, the largest activity level. Figure 15 shows that the Equipment Activity and Inventory table has 311,605 records. The large number of records reflects the many types of equipment used and the large number of Army Reserve and National Guard locations included in the table.

\begin{tabular}{|c|c|c|c|c|c|c|c|c|c|}
\hline \multicolumn{7}{|c|}{ 四 Equipment Activity and Inventory : Table } & \multicolumn{3}{|c|}{$-a x$} \\
\hline | Service & Location & FY & Quarter & Service_Equip_Name & Nomenclature & Density & Activity & Activity Un - & \\
\hline USA & FT LEWIS & 2002 & 1 & M1038 & TRUCK UTIL TROOP/CGO HMMW M1038 & 171 & 97099 & miles & \\
\hline USA & FT LEWIS & 2002 & 1 & M106A2 & CARRIER MORTAR 107MM SP M106A2 & 6 & & miles & \\
\hline USA & FT LEWIS & 2002 & 1 & M1070 & TRUCK TRACTOR HET M1070 & 4 & 1496 & miles & \\
\hline USA & FT LEWIS & 2002 & 1 & M1074 & TRUCK CARGO HEAVY PLS TRANS M1074 & 28 & 15615 & miles & \\
\hline USA & FT LEWIS & 2002 & 1 & M1078-3385 & TRUCK CARGO LMTV M1078 & 109 & 73951 & miles & \\
\hline USA & FT LEWIS & 2002 & 1 & M1079-3384 & TRUCK VAN LMTV M1079 & 10 & 1402 & miles & \\
\hline USA & FT LEWIS & 2002 & 1 & M1081-1899 & TRUCK CARGO LMTV LAPES/AD WW M1081 & 3 & 333 & miles & \\
\hline USA & FT LEWIS & 2002 & 1 & M1081-3064 & TRUCK CARGO LMTV LAPES/AD M1081 & 30 & 21793 & miles & \\
\hline USA & FT LEWIS & 2002 & 1 & M1083-1895 & TRUCK CARGO MTV WW M1083 & 9 & 5528 & miles & \\
\hline USA & FT LEWIS & 2002 & 1 & M1083-3386 & TRUCK CARGO MTV M1083 & 2 & 2410 & miles & \\
\hline USA & FT LEWIS & 2002 & 1 & M1083A1-3884 & TRUCK CARGO MTV WW M M1083A1 & 26 & 16511 & miles & \\
\hline USA & FT LEWIS & 2002 & 1 & M1089-4528 & TRUCK WRECKER MTV WW M1089 & 5 & 493 & miles & \\
\hline USA & FT LEWIS & 2002 & 1 & M1090-4529 & TRUCK DUMP MTV M1090 & 87 & 37068 & miles & \\
\hline USA & FT LEWIS & 2002 & 1 & M1093-3063 & TRUCK CARGO MTV LAPES/AD M1093 & 4 & 653 & miles & \\
\hline USA & FT LEWIS & 2002 & 1 & M1097 & TRUCK UTIL HVY VARIANT HMMMW M1097 & 50 & 15497 & miles & \\
\hline USA & FT LEWIS & 2002 & 1 & M1097A1 & TRUCK UTIL HVY VARIANT HMMWN M1097 & 32 & 28308 & miles & \\
\hline USA & FT LEWIS & 2002 & 1 & M1097A2 & TRUCK UTIL HVY VARNT HMMWN M1097A2 & 99 & 56088 & miles & \\
\hline USA & FT LEWIS & 2002 & 1 & M109A3-1636 & TRUCK VAN SHOP 21/2TON M109A3 & 10 & 461 & miles & \\
\hline USA & FT LEWIS & 2002 & 1 & M109A3-1637 & TRUCK VAN SHOP 21/2TON WW M109A3 & 4 & 88 & miles & \\
\hline USA & FT LEWIS & 2002 & 1 & M109A6 & HOWITZER MEDIUM SP 155MM M109A6 & 1 & 135 & miles & \\
\hline USA & FT LEWIS & 2002 & 1 & M1114 & TRUCK UTIL EXP CAPACITY UP-ARMORED HMMWN & 9 & 5899 & miles & \\
\hline USA & FT LEWIS & 2002 & 1 & M113A2 & CARRIER PERSONNEL FT M113A2 & 1 & 65 & miles & \\
\hline USA & FT LEWIS & 2002 & 1 & M113A3 & CARRIER PERSONNEL FT (RISE) M113A3 & 27 & 3115 & miles & $\nabla$ \\
\hline Record: $|1|$ & & 1.1 & D* of 31 & 1605 & & & & \pm & \\
\hline
\end{tabular}

Figure 15. Data from the Equipment Activity and Inventory table. 
One of the most challenging aspects encountered during the population of the Equipment Activity and Inventory table was matching the MDS and MDS Name information obtained from OSMIS with a corresponding representative record from the Equipment table. This task was challenging because the MDS information was often not part of the Nomenclature information found in the Equipment table or multiple records in the Equipment table had this information. In many instances, the confusion could be resolved by using the OSMIS facility for looking up equipment by LIN and NSN, but this was a very tedious process. In other cases, references to the MDS or MDS Name had to be found from technical manuals and other Internet resources.

One outcome of resolving OSMIS equipment identification with the equipment table was the creation of three "generic" equipment names. These names were "Generic TRUCK CARGO 21/2TON M35-LD465-1”, "Generic TRUCK CARGO 5TON M54LD465-1", and "Generic TRUCK CARGO 5TON M54-LDS465-1." The generic names were created because there were a large number of MDS designations that were related to a single vehicle type. For example, the Nomenclature name "Generic TRUCK CARGO 21/2TON M35-LD465-1" corresponded to MDS designations of M109, M109A1-8365, M109A2-8308, M109A2-8313, M185, M185A2, M185A3, M275A2-1640, M275A2-1641, M756A2, and M764.

Two new names were also created in the Equipment table when none of the existing records corresponded to an MDS designation reported by OSMIS or the TAMCN description reported by the Navy VAMOSC system. For the Army, the new Nomenclature names are "SMALL UNIT SUPPORT VEHICLE (SUSV)" and "BRADLEY LINEBACKER." For the USMC, the new Nomenclature names are "AN/TWQ-1 Avenger," "Mobile EW Support System, AN/MLQ-36," "Radio Set, AN/MRC-145A," and "Radio Terminal Set, AN/MRC-142." In all other cases, the OSMIS and Navy VAMOSC equipment identifications were resolved with records from the Equipment table. In some instances, more than one record from the Equipment table could have been linked with an Army or USMC equipment designation, but in these cases only one of the Equipment records was selected. Some records were also created in the Equipment table that did not have any linked records in the Equipment Activity and Inventory table.

\section{Installations Data}

The Installations table was created to link a location to the Army and USMC activity and inventory information. Figure 16 shows some data from the Installation table including some major Forces Command (FORSCOM) installations where a large volume of training occurs. The table includes fields for the Service, Command, In- 
stallation, City, and State. An extraction from the service and installation name information from the Equipment Activity and Inventory table initially populated this table. Unfortunately, the data from OSMIS indicated only a location name. For smaller facilities, the name usually was that of the nearest town or city. These location names were occasionally a contraction of the full name, and these contractions were not always consistent. For the first cut, the command, city, and state data were taken from the DoD FY2002 Base Structure Report (ODUSD 2002). For many of the small National Guard and Army Reserve facilities, information on city, state, and command was found through Internet resources that list government entities within cities.

The locations reported from the Navy VAMOSC system are not physical locations but organizational structures within the USMC logistics system. The following locations are reported in the USMC portion of the Navy VAMOSC system:

- I Marine Expeditionary Force (MEF)

- II MEF

- III MEF

- Depot Maintenance Float Allowance (DMFA)

- Enhanced Equipment Allowance Pool (EEAP)

- General Support

- Mobilization Allowance (MOB)

- Maritime Prepositioning Force (MPF)

- Net War Reserve Materiel Requirement (Net WRMR)

- Norway Air-Landed Marine Expeditionary Brigade

- Reserve, In Stores Assets

- Reserve Training Allowance Pool (Reserve T/A)

- Special Mission Forces.

After the Installation table was created, it contained locations that were not in the United States. These installations and the associated records in the Equipment Activity and Inventory table needed to be removed because the database was developed to look at diesel-powered off-road equipment that was regulated in the United States. Since MS Access has a cascade delete capability for linked tables, this feature was temporarily activated so that any record deleted in the Installation table would also cause the deletion of all related records in the Equipment Activity and Inventory table. 


\begin{tabular}{|c|c|c|c|c|c|c|}
\hline \multicolumn{5}{|c|}{ 曲 Installations : Table } & \multicolumn{2}{|c|}{$-\mid \square x$} \\
\hline & Service & Command & Installation & City & State & $\Delta$ \\
\hline+ & USA & FORSCOM & FT BRAGG & Fayetteville & $\mathrm{NC}$ & \\
\hline+ & USA & FORSCOM & FT CAMPBELL & Clarksville & TN & \\
\hline+ & USA & FORSCOM & FT CARSON & Colorado Spring & $\mathrm{CO}$ & \\
\hline+ & USA & FORSCOM & FT DRUM & Watertown & NY & \\
\hline+ & USA & FORSCOM & FT GILLEM & Forest Park & GA & \\
\hline+ & USA & FORSCOM & FT HOOD & Killeen & $\mathrm{TX}$ & \\
\hline+ & USA & FORSCOM & FT IRWIN & Barstow & $\mathrm{CA}$ & \\
\hline+ & USA & FORSCOM & FT LEWIS & Tacoma & WA & \\
\hline+ & USA & FORSCOM & FT MCPHERSON & Forest Park & GA & \\
\hline+ & USA & FORSCOM & FT POLK & Leesville & LA & \\
\hline+ & USA & FORSCOM & FT RILEY & Junction City & $\mathrm{KS}$ & \\
\hline+ & USA & FORSCOM & FT STEWART & Hinesville & GA & \\
\hline+ & USA & FORSCOM & HARTFORD & Hartford & AL & \\
\hline+ & USA & FORSCOM & HUNTER AAF & Savannah & GA & \\
\hline+ & USA & FORSCOM & MIDLAND & Midland City & AL & \\
\hline+ & USA & FORSCOM & NEW BROCKT & New Brockton & AL & \\
\hline+ & USA & FORSCOM & OZARK & Ozark & AL & \\
\hline+ & USA & FORSCOM & VANCOUVER & Vancouver & WA & \\
\hline+ & USA & FORSCOM & YAKIMA.FC & Yakima & WA & \\
\hline+ & USA & MDW & FT AP HILL & Bowling Green & $\mathrm{VA}$ & \\
\hline+ & USA & MDW & FT BELVOIR & Alexandria & $\mathrm{VA}$ & \\
\hline+ & USA & MDW & FT HAMILTON & New York & NY & \\
\hline+ & USA & MDW & FT MCNAIR & Washington & $\mathrm{DC}$ & \\
\hline+ & USA & MDW & FT MEADE & Baltimore & $\mathrm{MD}$ & \\
\hline+ & USA & MDW & FT MYER & Arlington & VA & \\
\hline+ & USA & MDW & FT RITCHIE & Waynesboro & $\mathrm{MD}$ & \\
\hline+ & USA & MEDCOM & FT DETRICK & Frederick & $\mathrm{MD}$ & \\
\hline+ & USA & MEDCOM & FT SAM HOUSTON & San Antonio & $\mathrm{TX}$ & \\
\hline+ & USA & MEDCOM & WALTER REED & Silver Spring & $\mathrm{MD}$ & \\
\hline+ & USA & MTMC & SUNYPTMOT & Wilmington & NC & \\
\hline+ & USA & TRADOC & CARLSLE B & Carlisle & PA & \\
\hline Recor & 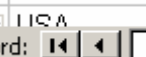 & 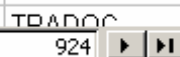 & $\begin{array}{l}\text { FT RFMIMULIR } \\
* \text { of } 1179\end{array}$ & ralumbur & $\Omega A$ & $\nabla$ \\
\hline
\end{tabular}

Figure 16. Data from the Installation table.

\section{Summary}

This chapter describes the work done to create and populate a database that contains DoD installation, fuel, equipment, engine, and equipment activity information. Each of these data categories were placed in their own tables and relationships were set up among the tables as shown in Figure 7. Since engine, equipment, and activity information came from different sources; a large effort was undertaken to standardize equipment name and engine manufacturer and model number information across the database. The database was designed to provide a structure for developing queries and reports to analyze information across all the services. Chapter 6 describes the data analysis that was per-formed for this project using this database. 


\section{User Interface}

The user interface was designed as a tool for users to browse through data and display or print reports that summarize the information in useful ways. The user interface is actually a separate MS Access database containing the forms, queries, reports, and associated Visual Basic for Applications code that constitute the interface. The interface requires the user to have MS Access 2000 or above. The user begins by opening: "DoD_Diesel_Off_Road_Activity_Interface.mde." An MS Access file with the mde extension contains working versions of the database objects but does not allow users to modify or delete any of the database objects. When the interface file is opened, the user is prompted to select a data set file as shown in Figure 17.

The highlighted file (Figure 17) is "Original_DoD_Diesel_Off_Road_Data.org" and contains the original data included in the database described in Chapter 3. For ease of use, this file should be in the same Windows folder as the user interface database. The file is password protected and encrypted to prevent changes to the information. However, users are allowed to create their own versions of this database. The files "Test1.scn" and "Test2.scn" are examples of user-created datasets.

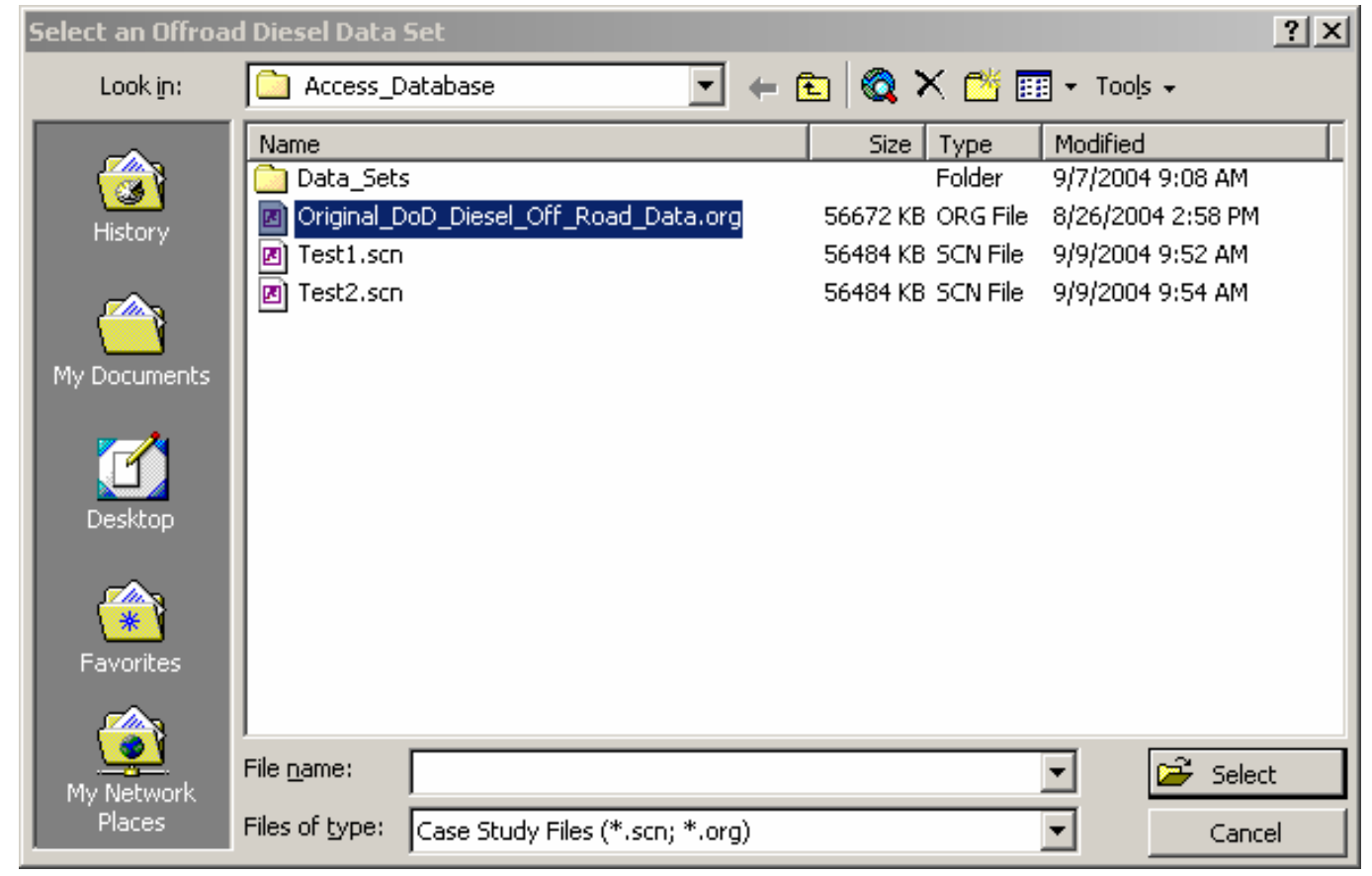

Figure 17. Data set selection screen. 
After a user selects a file, the file selection screen disappears, the hourglass cursor appears, and the message "Creating temporary database. Please wait..." is displayed on the bottom of the screen. At this point, the user interface application is creating a temporary database that is an exact copy of the selected file. The user interface interacts with the temporary database and users are able to save changes upon exiting the interface or selecting another file. The use of a temporary database allows users to make live changes to the database while maintaining a copy of the original information if the user wants to maintain that dataset. Because of the large amount of information, the creation of the temporary database may take several minutes. The amount of time required will improve with faster processors or more system memory.

\section{Opening Screen}

After the temporary database is created, the opening screen of the user interface appears as shown in Figure 18. This screen contains push button controls for viewing and modifying data, report generation, saving and loading case study files, and exiting the user interface. The top of the opening screen displays the name of the case study database file name.

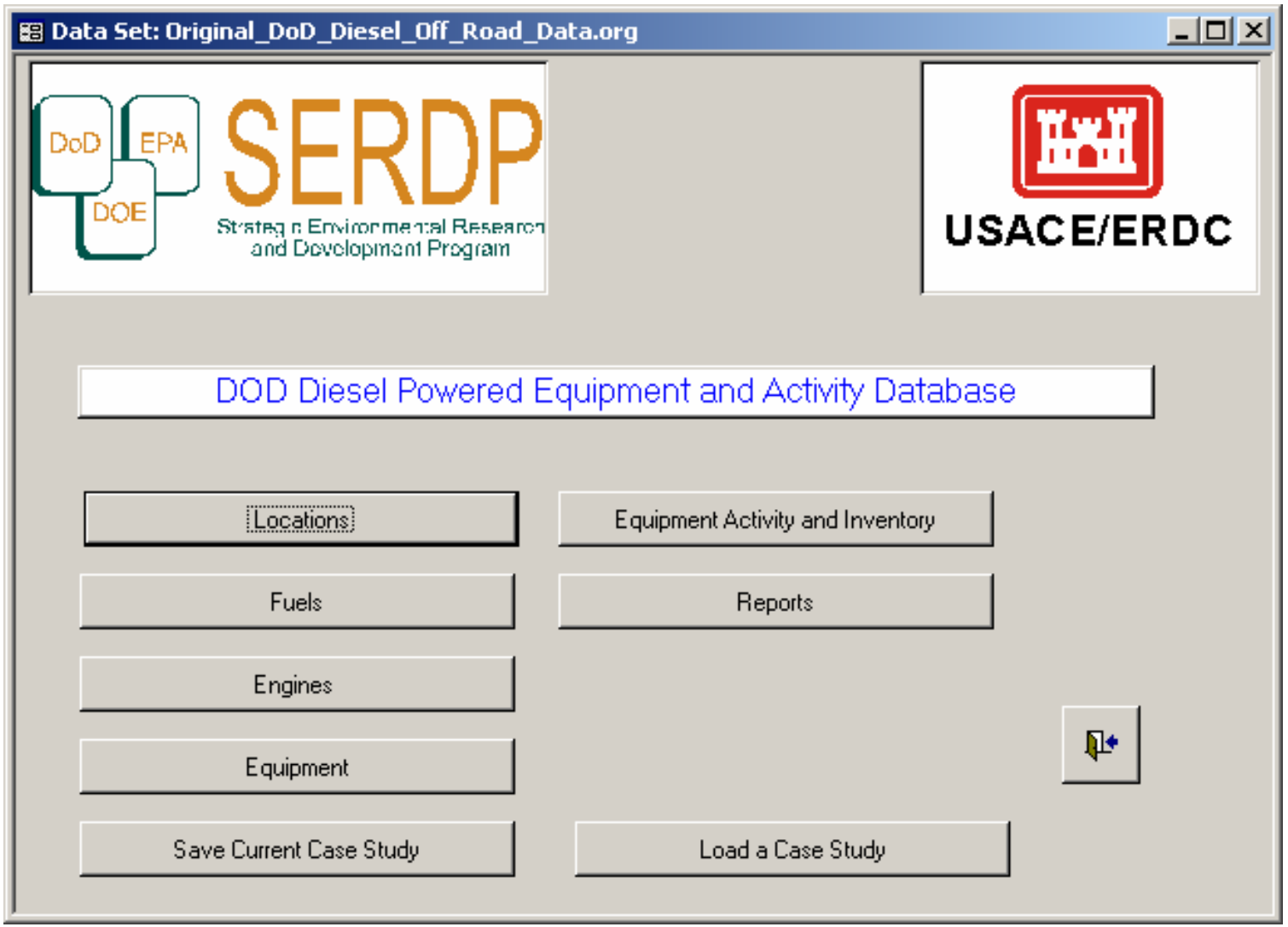

Figure 18. Opening screen of the user interface. 
If a user elects to save a file, a screen similar to Figure 17 is displayed except that the file "Original_DoD_Diesel_Off_Road_Data.org" is not shown so that users will not try to overwrite the original data file. However, users do have the option to overwrite an existing case study file or save the information in a new file name. The saving operation could take several minutes, and the top of the opening screen will show the name of the saved file. If a user chooses to load a new file, again a screen similar to Figure 17 is displayed and the original dataset file is displayed since users may want to load this file. However, if a user has modified information before choosing to load a new file, the interface will first provide the option of saving the modified file.

\section{Forms for Data Display and Editing}

The buttons for Locations, Fuels, Engines, Equipment, and Equipment Activity and Inventory open up forms that allow display and modification of data found in the tables with names the same as the buttons. For example, Figure 19 shows the Engines form that is displayed after selecting the Engines button. All the forms will display the form name on the top of the form and display information from more than one record at a time. On the top right of each form will be standard buttons for minimizing, maximizing/restoring, and closing the form. The bottom of each form will include record navigation and new record entry buttons.

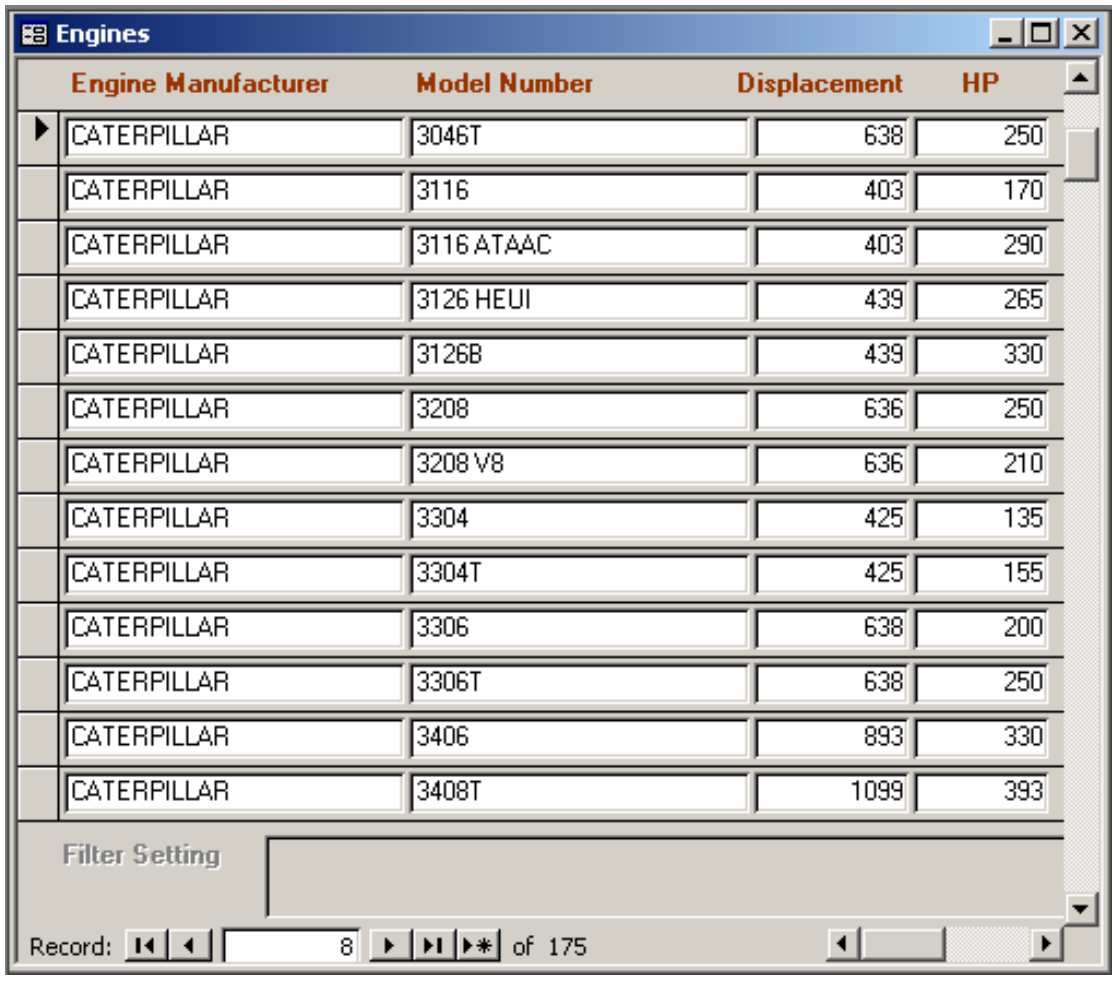

Figure 19. Engines form. 
The Enter or Tab key will move from field to field and the Page Up and Page Down key will move to the next and previous records respectively. The Delete key will either delete information found in a field or attempt to delete the entire record if the entire record has been previously selected by clicking on the bar to the left of a record. The interface will ask for confirmation before deleting a record. Changes are not actually stored in the linked table until the user moves to another record.

The custom toolbar shown in Figure 20 is also displayed at the top of each form. This toolbar gives users access to some useful functions built in to MS Access. Table 9 briefly describes the actions that each of these buttons will perform. As was discussed in the previous paragraph, some of these actions can also be performed using the keyboard or buttons included on the form.

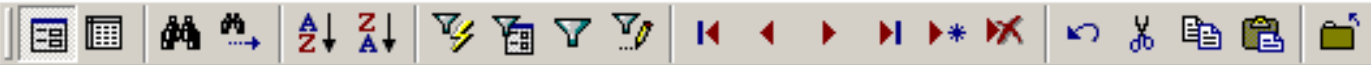

Figure 20. Custom toolbar displayed on the top of forms.

Table 9. Actions performed by each of the buttons in the custom toolbar.

\begin{tabular}{|c|c|c|c|}
\hline Icon & Action & Icon & Action \\
\hline E圆 & Switch to the form view & IS & Go to the first record \\
\hline 阐 & Switch to the datasheet view & 4 & Go to the previous record \\
\hline 4 & Search and replace text & 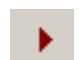 & Go to the next record \\
\hline$\stackrel{\leftrightarrow}{\leftrightarrow}$ & Find the next occurrence of text & M & Go to the last record \\
\hline$\stackrel{A}{Z} \downarrow$ & $\begin{array}{l}\text { Order the records in ascending order } \\
\text { by the current field(s) }\end{array}$ & * & Enter a new record \\
\hline$Z_{A} \downarrow$ & $\begin{array}{l}\text { Order the records in descending order } \\
\text { by the current field(s) }\end{array}$ & $x$ & Delete the current record \\
\hline$\nabla_{y}$ & $\begin{array}{l}\text { Filter records using the highlighted } \\
\text { data }\end{array}$ & W & $\begin{array}{l}\text { Cut the highlighted data into the clip- } \\
\text { board }\end{array}$ \\
\hline 面 & $\begin{array}{l}\text { Filter records by entering conditions } \\
\text { on the form }\end{array}$ & 臥 & $\begin{array}{l}\text { Copy the highlighted data into the } \\
\text { clipboard }\end{array}$ \\
\hline$\nabla$ & Toggle the current filter on or off & 四 & $\begin{array}{l}\text { Paste the clipboard data at the cursor } \\
\text { point }\end{array}$ \\
\hline$\nabla /$ & Open the advanced filter/sort screen & 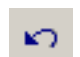 & Undo the previous change \\
\hline & & $\square^{5}$ & Exit the form \\
\hline
\end{tabular}


The 圆 and 疄 buttons cause the form view and datasheet view to be displayed, respectively. Figure 19 shows the Engines form view and Figure 21 shows the datasheet view of the same form. The datasheet view is similar to a spreadsheet table with the field names as the column headings. In the datasheet view, users can modify the width of columns and change the relative position of columns. Several columns can be selected and be used together to change the display order with the leftmost column being used as the primary sort key followed in order by selected columns to the right.

\begin{tabular}{|c|c|c|c|c|}
\hline \multicolumn{3}{|l|}{ Eg Engines } & \multicolumn{2}{|c|}{$-\square x$} \\
\hline \begin{tabular}{|l|l} 
& Engine_Manufacturer
\end{tabular} & Model_Number & Displacement & HP & $\Delta$ \\
\hline CATERPILLAR & $3046 \mathrm{~T}$ & 638 & 250 & \\
\hline CATERPILLAR & 3116 & 403 & 170 & \\
\hline CATERPILLAR & 3116 АТААС & 403 & 290 & \\
\hline CATERPILLAR & 3126 HEUI & 439 & 265 & \\
\hline CATERPILLAR & 3126B & 439 & 330 & \\
\hline CATERPILLAR & 3208 & 636 & 250 & \\
\hline CATERPILLAR & 3208 V8 & 636 & 210 & \\
\hline CATERPILLAR & 3304 & 425 & 135 & \\
\hline CATERPILLAR & 3304T & 425 & 155 & \\
\hline CATERPILLAR & 3306 & 638 & 200 & \\
\hline CATERPILLAR & $3306 \mathrm{~T}$ & 638 & 250 & \\
\hline CATERPILLAR & 3406 & 893 & 330 & \\
\hline CATERPILLAR & $3408 \mathrm{~T}$ & 1099 & 393 & \\
\hline CATERPILLAR & 342 & 1286 & 486 & \\
\hline CATERPILLAR & 343T/A & 893 & 334 & \\
\hline CATERPILLAR & 7B.J TYPE ॥ & 243 & 85 & \\
\hline CATERPILLAR & 9RM TYPE I & 243 & 85 & \\
\hline CATERPILLAR & $\mathrm{C}-12$ & 830 & 425 & $\nabla$ \\
\hline Record: $14|1| \Gamma$ & 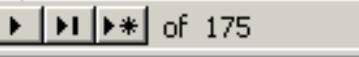 & & & \\
\hline
\end{tabular}

Figure 21. Datasheet view of the Engines table.

The button is used to search for text or to search and replace text. Pressing this button opens up the MS Access Find and Replace form as shown in Figure 22. This single form can be used for both finding and replacing data and the form offers several options for improving the search through the table. The $\stackrel{\boldsymbol{H}_{*}}{\rightarrow}$ button will repeat the most recently performed search. 


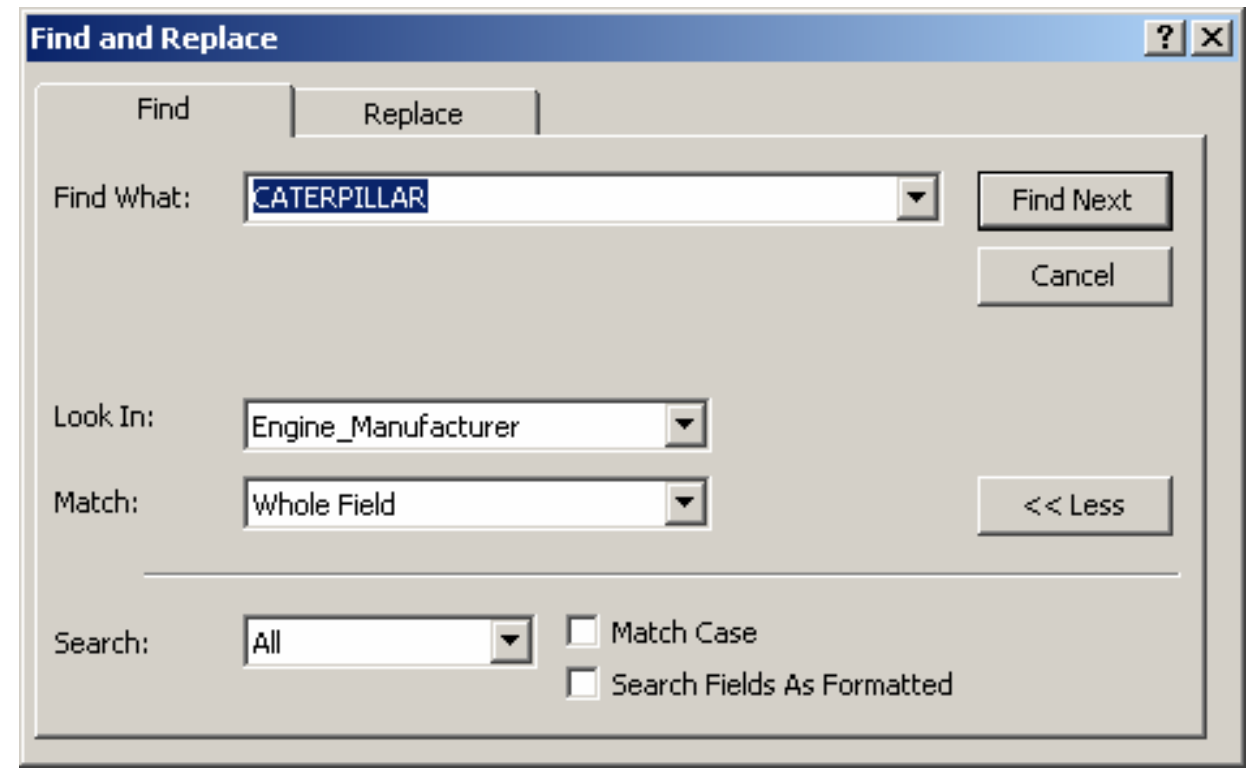

Figure 22. MS Access Find and Replace form.

The $\stackrel{\stackrel{A}{Z} \downarrow}{\text { and }} \stackrel{\mathrm{Z} \downarrow}{\mathrm{A}} \downarrow$ buttons will sort the records in the current view in ascending and descending order respectively. In the form view, the order will be based on the field where the cursor is located when one of the buttons are pushed. In the datasheet view, several columns can be used to affect the sort order. After a sort operation is performed, the record pointer will move to the first record in the new view.

A number of MS Access features allow users to filter the display of data in the form and datasheet views. A filter allows users to view a subset of the data based on conditions placed on the view. The "ily "filter by selection" button places a simple condition on the current view that is based on the field where the cursor is located when the button is selected. The filter will be $\mathrm{X}=\mathrm{Z}$ where $\mathrm{X}$ is the name of the field and $\mathrm{Z}$ is the value of the field where the cursor is located. For example, if the Engines form is displayed and the cursor is in the Engine_Manufacturer field and the value for the current record is "CATERPILLAR" then the filter becomes Engine_Manufacturer = "CATERPILLAR" and only records where the engine manufacturer is Caterpillar are displayed. The ${ }^{\nabla /}$ button also toggles the $\nabla$ "apply filter button" so that the results of the filter are viewed immediately. If users 
continue to press the $\mathbb{V}$ button in different fields, the original condition will be expanded by adding new "AND" conditions based on each of the new fields and their values. A new condition will be started if a user untoggles the $\nabla$ button and selects the $\nabla^{\prime}$ button again.

The 戝 button activates the "filter by form" feature that allows users to enter filter conditions in a form or datasheet view. The conditions can be the value of a field or users can enter more complex conditions. Figure 23 shows an example of conditions entered in the "Look for" and "Or" tabs of the Engines filter-by form screens and the results of these conditions shown in the Engines form view window. In this example, engines manufactured by both Caterpillar and Continental are displayed on the form. The form view shown in Figure 23 also illustrates the "Filter Setting" text box that will display the current filter settings. This text box is included on the bottom of all forms that display data from database tables. The forms will also display the text "(Filtered)" to the right of the record navigation buttons on the bottom of the form. Printed or online MS Access help can advise users further on ways of filtering data using the filter-by form feature. 


\begin{tabular}{l}
\hline Eg Engines: Filter by Form \\
\begin{tabular}{|l|c|c|c|c|}
\hline & Engine_Manufacturer & Model_Number & Displacement & HP \\
\hline & "CATERPILLAR" & & $>300$ \\
\hline Look for $\mathrm{B}$ Or $\mathrm{K}$ or & & & \\
\hline
\end{tabular}
\end{tabular}

\begin{tabular}{l}
\hline E: Engines: Filter by Form \\
\begin{tabular}{|c|c|c|c|c|}
\hline & Engine_Manufacturer & Model_Number & Displacement & HP \\
\hline & "CUMMINS ENGINE" & & & $>300$ \\
\hline \hline Look for $\lambda$ Or $\mathrm{N}$ Or & & \\
\hline
\end{tabular}
\end{tabular}

\begin{tabular}{|c|c|c|c|c|}
\hline \multicolumn{3}{|c|}{ Eg Engines } & \multirow[b]{2}{*}{ Displacement } & $-10 x$ \\
\hline & Engine Manufacturer & Model Number & & HP \\
\hline D & CATERPILLAR & $3126 \mathrm{~B}$ & \begin{tabular}{|l|l|}
439 \\
\end{tabular} & $\overline{3330}$ \\
\hline & CATERPILLAR & 3406 & $\mid \overline{893}$ & $\overline{330}$ \\
\hline & $\longdiv { \text { CATERPILLAR } }$ & $\overline{3408 \mathrm{~T}}$ & $\mid \overline{1099}$ & 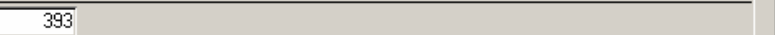 \\
\hline & CATERRILLAR & 342 & 1286 & $\overline{4866}$ \\
\hline & CATERPILLAR & $343 T / \mathrm{A}$ & 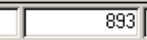 & $\overline{3334}$ \\
\hline & CATERRPILLAR & $\overline{C-12}$ & 830 & 425 \\
\hline & CATERPILLAR & $\overline{D 342}$ & 1246 & 486 \\
\hline & CATERPILLAR & $\overline{D 342 \mathrm{~N}}$ & $\overline{\mid 7246}$ & $\overline{4111}$ \\
\hline & CATERPILLAR & $D 343 T / A$ & $\overline{8993}$ & $\overline{334}$ \\
\hline & CATERRIILLAR & D398TA & 2946 & 938 \\
\hline & CUMMMINS ENGIINE & KT1150 & 1150 & 380 \\
\hline & CUMMINSS ENGINE & $\widehat{\text { KTA2300G }}$ & $\overline{2300}$ & 1235 \\
\hline & CUMMMINS ENGINE & NT-380-1 & 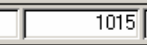 & 335 \\
\hline & CUMMMINS ENGIINE & NTC 400 & 855 & 400 \\
\hline & CUMMINSS ENGINE & NTTA-855-P450 & 855 & $4 \overline{450}$ \\
\hline & CUMMINSS ENGINA & QSM 11 & "6611 & $\overline{400}$ \\
\hline & CUMMMINS ENGINE & VT 400 & 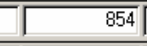 & 400 \\
\hline & CUMMININS ENGINE & VTA28G1 & $\overline{1710}$ & 750 \\
\hline & CUMMMINS ENGIINE & VTA.903T & 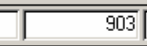 & $\overline{500}$ \\
\hline & CUMMMINS ENGINNE & VTA903-T525 & 903 & $\overline{525}$ \\
\hline * & & & $\overline{0}$ & $\overline{0}$ \\
\hline & Filter Setting & gine_Manufacturer="CATEF & LLAR"),AND (Engin & 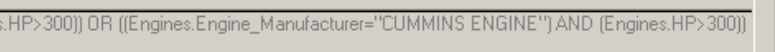 \\
\hline & cord: $14 \mid 4 \Gamma$ & $|\boldsymbol{n |}| \boldsymbol{*} \mid \mathbf{\text { of }} 20$ (Filtered) & 11 & 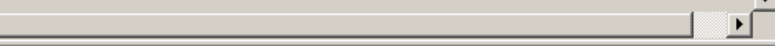 \\
\hline
\end{tabular}

Figure 23. Filter by form conditions and results for the Engines table.

The ${ }^{\nabla /}$ button opens the advanced filter/sort screen. This screen is the MS Access query design screen that allows users to enter very complicated filter and sort conditions. Additional information about using query design screens can be found in an MS Access user manual or from online help. 
The $\mathbf{M}, \mathbf{V}$, and $\mathbf{M}$ buttons are used for navigating the records on a form and are used to go to the last record, the next record, the previous record, and the first record, respectively. The navigation buttons will apply to the currently active sort and filter. The ${ }^{*}$ button is used to enter a new record. Selecting this button will move the record pointer to a blank record on the screen where the user fills in the appropriate information. This can also be accomplished using the same record navigation button on the bottom of the form or manually using the keyboard or mouse. The ${ }^{\mathbb{K}}$ button will attempt to delete the current record or multiple records if more than one is selected. Users will be asked for confirmation before deleting records since the deletion operation is permanent.

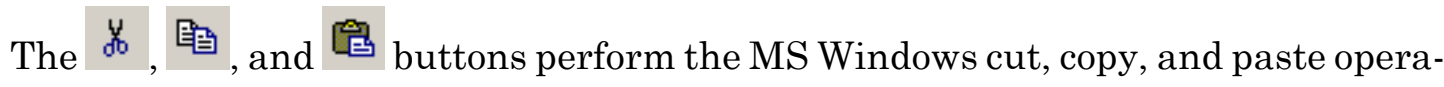
tions, respectively. These operations should be familiar to everyone who has worked with other MS Windows applications. The $n$ button performs an undo operation on the most recent database change. There is only one level of undo, and record deletions cannot be undone. The $\square^{5}$ button exits the form and returns to the opening screen of the user interface.

The remaining forms for displaying and editing data from the tables work the same way as the Engines form and use the same custom toolbar. Figure 24 shows the Installations form, Figure 25 shows the Fuels form, Figure 26 shows the Equipment form, and Figure 27 shows the Equipment Activity and Inventory form. 


\begin{tabular}{|c|c|c|c|c|c|}
\hline \multicolumn{5}{|c|}{ 回 Installations } & \multirow{2}{*}{\begin{tabular}{r|r|}
$-|\square|$ \\
\end{tabular}} \\
\hline Service & Installation & Command & City & State & \\
\hline USA & PRES MONT & TRADOC & Monterey & $\overline{C A}$ & \\
\hline USA & FT STORY & TRADOC & Norfolk & $\sqrt{V A}$ & \\
\hline USA & FT KNOX & TRADOC & Radcliff & $\overline{K Y}$ & \\
\hline USA & $\overline{\text { FT SILL }}$ & TRADOC & Lawton & $\overline{O K}$ & \\
\hline USA & FT GORDON & TRADOC & Augusta & GA & \\
\hline USA & FT BENNING & TRADOC & Columbus & GA & \\
\hline USA & FT MONROE & TRADOC & Hampton & VA & \\
\hline USA & CARLSLE B & TRADOC & Carlisle & $\mathrm{PA}$ & \\
\hline USA & HAMPTON & TRADDOC & Hampton & VA & \\
\hline USA & FT BLISS & TRADOC & ElPaso & TX & \\
\hline USA & FT LEAVENWORTH & TRADOC & Leavenworth & KS & \\
\hline USA & FT LEE & TRADOC & Petersburg & $\sqrt{V A}$ & \\
\hline USA & FT LEONARD WOOD & TRADOCC & Waynesville & $\mathrm{MO}$ & \\
\hline USA & FT MCCLELLAN & TRADOC & Anniston & $A \mathrm{~L}$ & \\
\hline USA & FT HUACHUCA & TRADOC & Sierra Vista & $\widehat{A Z}$ & \\
\hline USA & FT JACKSON & TRADDOC & Columbia & SC & \\
\hline$\overline{U S A}$ & FT EUSTIS & TRADOC & Newport News & $\sqrt{V A}$ & - \\
\hline USA & FT RUCKER & TRADOC & Daleville & $A \mathrm{LL}$ & \\
\hline \multicolumn{6}{|c|}{ Filter Setting } \\
\hline Record: II & $983+11$ & 1* of 1179 & 11 & & 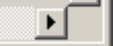 \\
\hline
\end{tabular}

Figure 24. Installation form.

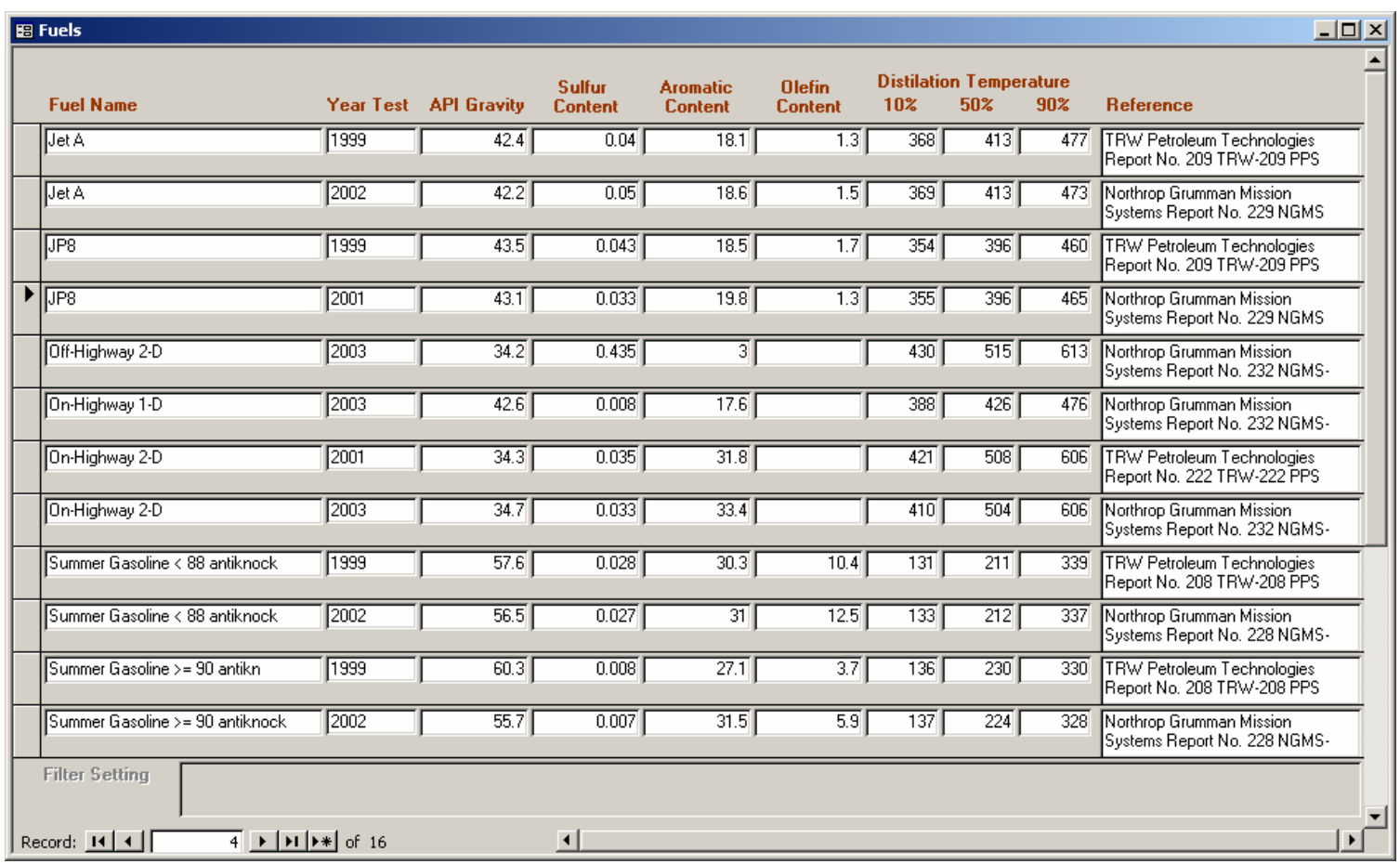

Figure 25. Fuels form. 


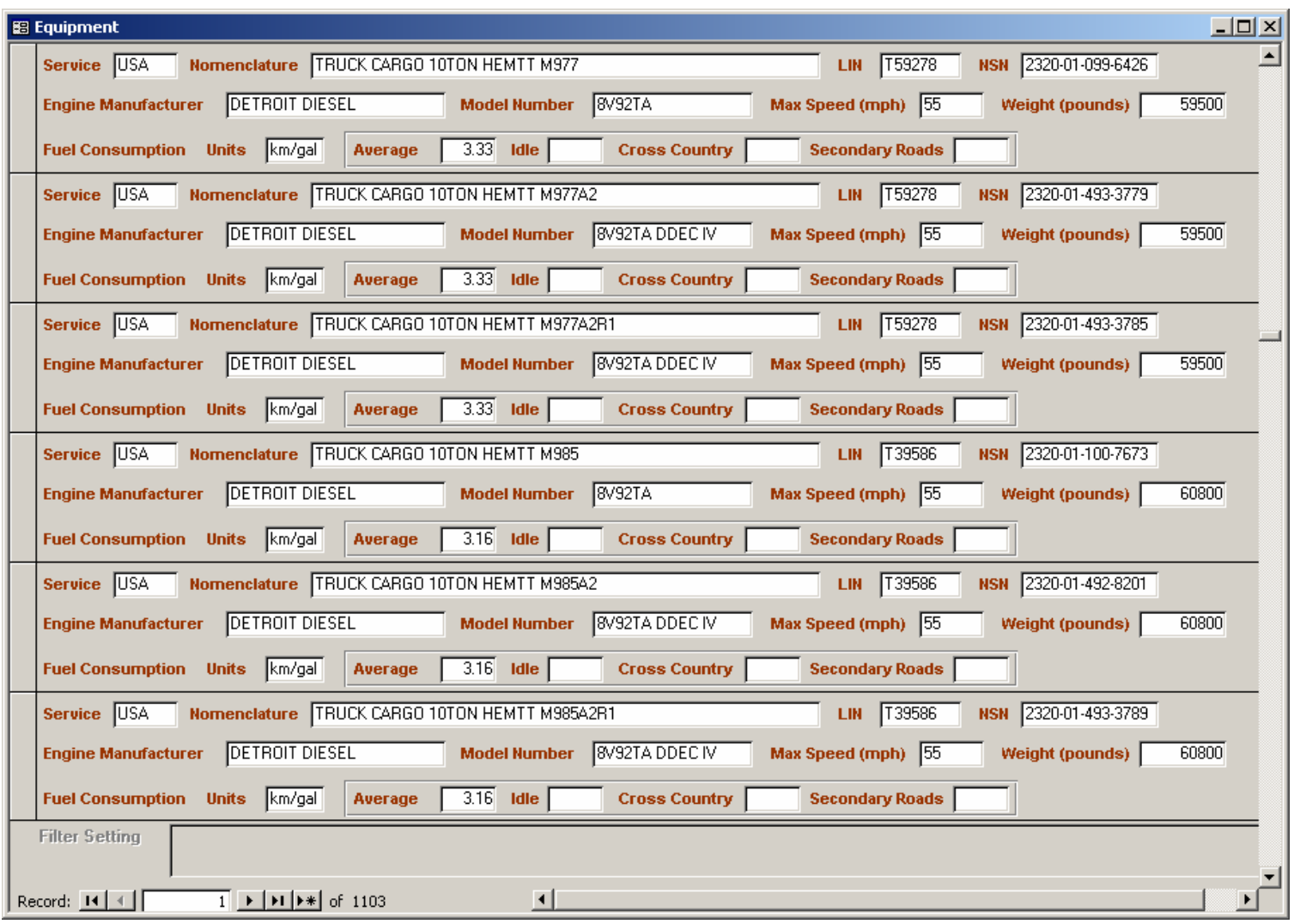

\section{Figure 26. Equipment form.}

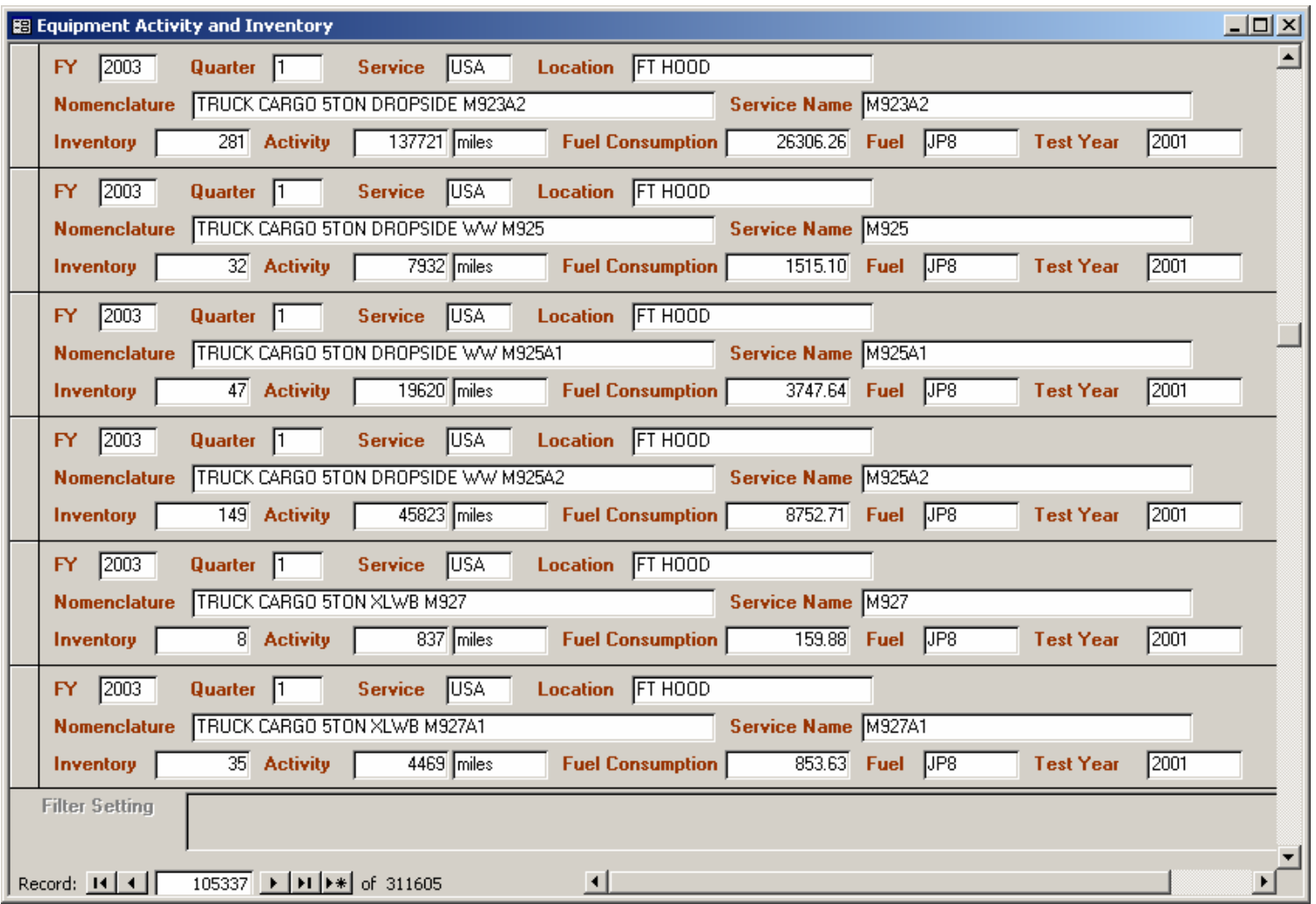

Figure 27. Equipment Activity and Inventory form. 


\section{Reports Generation}

The opening screen of the user interface also has a button for opening a report generation form. When the Reports button is selected, there will be a delay as the system fills in temporary tables that allow the selection of criteria for some of the reports. The Reports form first requires the selection of a report from a pick list and then presents users several options for setting conditions on the reports. The conditions will vary depending on the report that is selected and the conditions will default to the most inclusive. Figure 28 shows the Reports form after a user has selected the Engine Fuel Consumption report and has also elected to create a report showing only Army information from FY2003. Some condition selection lists will appear only after another related selection is made. For example, in Figure 28 the Installation selection list only appears after an individual service is selected. Users generate report previews by selecting the Preview button. Users can also send reports directly to a printer by selecting the Print button. When users select the Print or Preview button, report generation will cause a delay before the report results are printed or displayed.

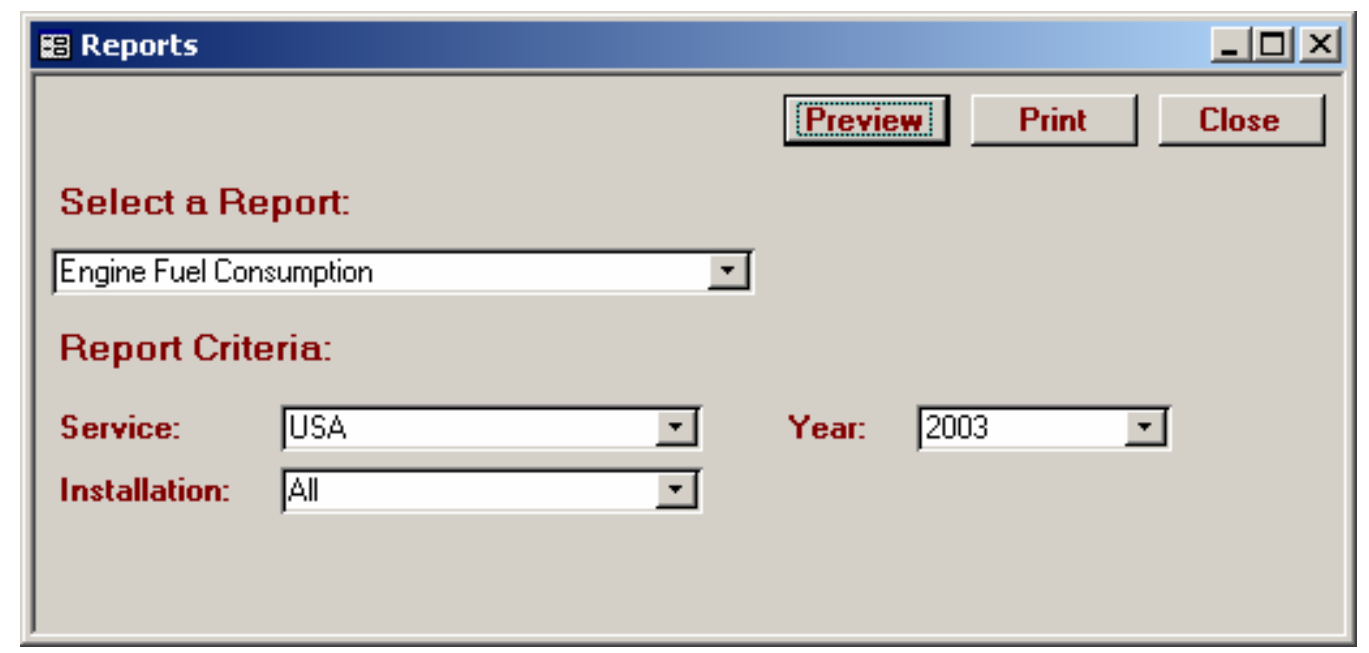

Figure 28. Report selection and criteria form.

The Reports form allows users to select from the following fuel consumption and inventory reports:

- Engine Fuel Consumption

- Engine Fuel Consumption with Equipment List

- Equipment Fuel Consumption

- Equipment Fuel Consumption with Installation List

- Installation Fuel Consumption

- Installation Fuel Consumption with Equipment List. 
Each report summarizes fuel consumption as indicated by the name of the report. For example, the Engine Fuel Consumption report shows total fuel consumption by engine models. The Engine Fuel Consumption with Equipment List also summarizes engine fuel consumption, but also lists fuel consumption of equipment that uses a particular engine type.

Figure 29 shows the report preview screen for the report and criteria conditions shown in Figure 28. As in all the reports, the report criteria are shown at the top of the page. The report preview is an MS Access feature that allows the user to view the report on the screen, set the zoom level of the report on the screen, create an MS Word document containing the report, modify the page setup for the report, and send the report to a printer.

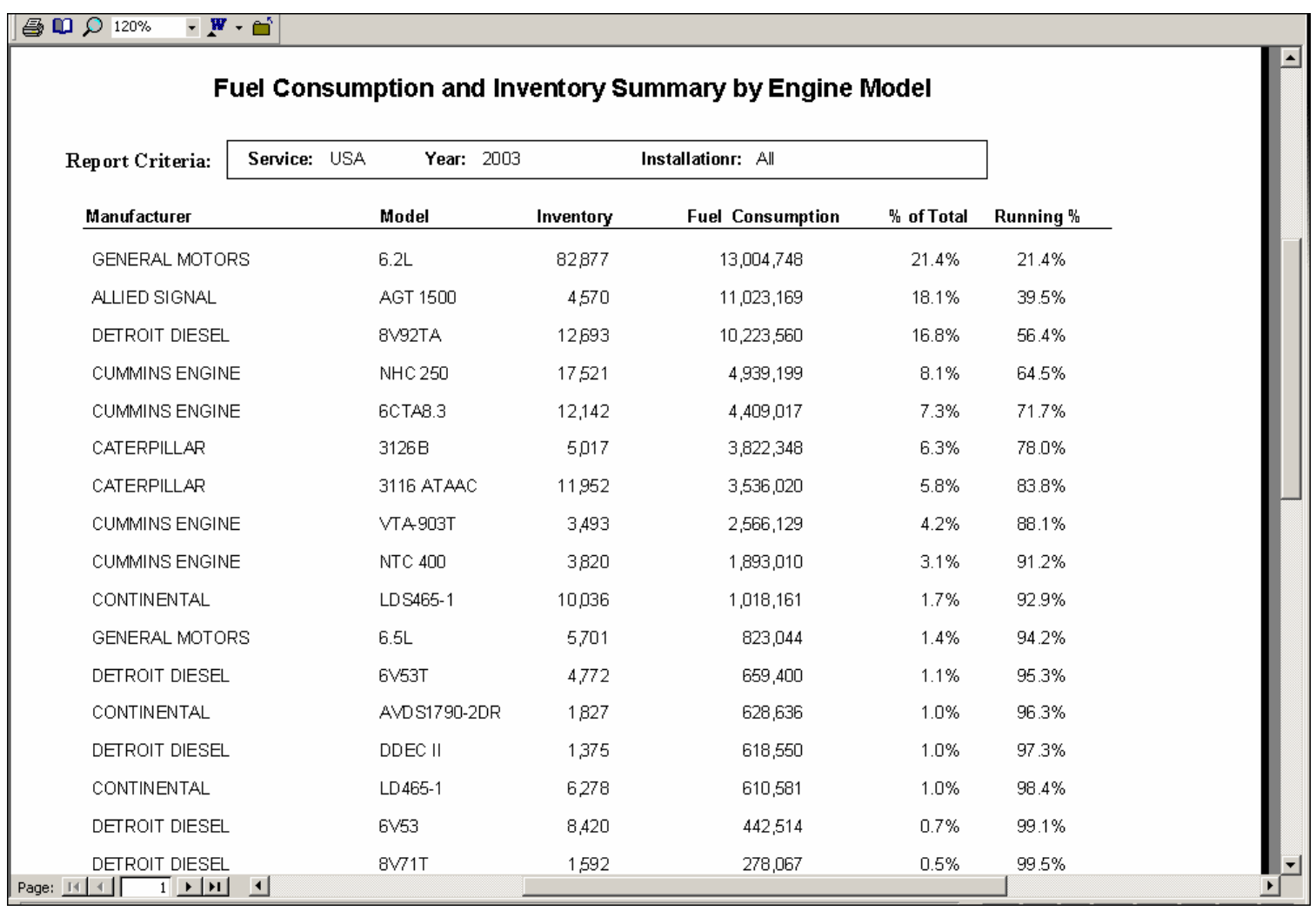

Figure 29. Report preview screen of the Engine Fuel Consumption report for 2003 Army data.

\section{Summary}

This chapter described the user interface that was designed as a tool for users to browse through data and display or print reports that summarize the information in useful ways. The user interface is an MS Access database that links to the information database described in Chapter 3 and the interface uses many of MS Access's built in controls. The interface allows users to connect to the original data or to 
modify this data and create new data sets. There are separate forms for viewing installation, fuel, engine, equipment, and equipment activity and inventory data. The forms allow user-specified views by filtering the data using options found in a tool bar. The interface also contains a report generation feature that allows users to select from several built-in reports and set criteria for the report that filter the results. The interface allows users without detailed knowledge of the MS Access database system a way to easily and safely interact with the large amount of provided data. 


\section{Data Analysis}

This chapter describes two types of data analyses that were performed using the developed database and user interface. The objective of the first analysis was to provide activity information that would show the types of diesel-powered off-road equipment used most frequently. The usage patterns provide information that is useful in determining the priority for engine emission testing. The objective of the second data analysis was to compare fuel usage reported by OSMIS with fuel usage information found in the Headquarters Redesigned Army Defense Utilities Energy Reporting System (DUERS) Data System (HQRADDS). This type of comparison could help to validate the OSMIS fuel usage information that is calculated from expected fuel usage rates and either vehicle miles driven or hours of operation.

\section{Army and USMC Emission Testing Priority}

One of the primary purposes of developing the DoD diesel-powered off-road equipment activity database was to help prioritize this equipment by the potential to generate engine emissions. The database report that is most useful for this purpose is the Engine Fuel Consumption report that totals fuel usage for each engine and presents the results in descending order of the totals. This report will tend to group similar types of equipment together since each diesel engine model will most often be used in different pieces of equipment that share a similar function. The data displayed in all the tables in this section were extracted from much more detailed reports. The Appendix contains the complete report results ob-tained when generating the Engine Fuel Consumption report and the Engine Fuel Consumption with Equipment List report for all services and for FY2003. These results were used to create Table 11 .

Table 10 shows results from this report for both the Army and the USMC for FY2001-2003. Table 10 includes a column displaying typical equipment that uses each engine type. The data indicates that the top five ranked engines account for more than 50 percent of the fuel usage, the top ten almost 78 percent, and the top 20 almost 92 percent. High mobility multi-purpose wheeled vehicles (HMMWVs); tanks (M1A1, M1A2); trucks (HEMTT, 5-ton, family of medium tactical vehicles [FMTV], 10-ton); the amphibious assault vehicle (AAV); the logistics vehicle system (LVS); and the Bradley fighting vehicle (M2A2, M3A2) use almost 80 percent of the fuel. Three generator sets and a forklift are included in Table 10, but the reported 
fuel usage is only from the USMC. This is because of the OSMIS problem (discussed in Chapter 2) of not reporting activity correctly for equipment that has usage measured in hours. If OSMIS did report activity for nonvehicular equipment correctly, then this type of equipment would certainly be more prominent in Table 10.

Table 10. Top 20 Army and USMC off-road diesel engine fuel consumptions for FY2001-2003.

\begin{tabular}{|c|c|c|c|c|c|c|c|}
\hline Rank & Manufacturer & Model & $\begin{array}{c}\text { Representative } \\
\text { Equipment }\end{array}$ & $\begin{array}{l}\text { Average } \\
\text { Inventory }\end{array}$ & $\begin{array}{c}\text { Fuel Usage } \\
\text { (gallons) }\end{array}$ & $\begin{array}{l}\text { Percent } \\
\text { of Total }\end{array}$ & $\begin{array}{l}\text { Running } \\
\text { Total (\%) }\end{array}$ \\
\hline 1 & GENERAL MOTORS & $6.2 \mathrm{~L}$ & HMMWV & 99,398 & $44,906,900$ & 17.5 & 17.5 \\
\hline 2 & ALLIED SIGNAL & AGT 1500 & M1A1, M1A2 & 4,673 & $40,630,794$ & 15.8 & 33.3 \\
\hline 3 & DETROIT DIESEL & 8V92TA & HEMTT & 13,694 & $29,108,653$ & 11.3 & 44.6 \\
\hline 4 & CUMMINS ENGINE & NHC 250 & 5-ton truck & 25,985 & $20,375,687$ & 7.9 & 52.5 \\
\hline 5 & DETROIT DIESEL & 6V53T & LAV, APC & 5,395 & $18,513,284$ & 7.2 & 59.7 \\
\hline 6 & CUMMINS ENGINE & 6СТА8.3 & 5-ton truck & 13,866 & $12,007,328$ & 4.7 & 64.4 \\
\hline 7 & CATERPILLAR & 3116 ATAAC & FMTV & 12,944 & $10,041,649$ & 3.9 & 68.3 \\
\hline 8 & CUMMINS ENGINE & VT400 & AAV & 1,147 & $9,449,304$ & 3.7 & 72.0 \\
\hline 9 & DETROIT DIESEL & $8 V-92$ & MK48 LVS & 1,308 & $8,379,559$ & 3.3 & 75.2 \\
\hline 10 & CUMMINS ENGINE & NTC 400 & 10-ton truck tractor & 4,103 & $6,020,515$ & 2.3 & 77.6 \\
\hline 11 & CUMMINS ENGINE & VTA-903T & $\mathrm{M} 2 \mathrm{~A} 2, \mathrm{M} 3 \mathrm{~A} 2$ & 3,528 & $5,628,003$ & 2.2 & 79.8 \\
\hline 12 & JOHN DEERE & 6466 6.8L & Tractor, Loader & 513 & $5,501,174$ & 2.1 & 81.9 \\
\hline 13 & CATERPILLAR & $3126 B$ & Stryker, FMTV & 3,018 & $4,840,063$ & 1.9 & 83.8 \\
\hline 14 & ALLIS CHALMERS & 3500 & $60-\mathrm{kW}$ generator & 1,023 & $4,504,264$ & 1.8 & 85.6 \\
\hline 15 & CONTINENTAL & LDS465-1 & M35A2, 2.5-ton truck & 11,227 & $3,851,595$ & 1.5 & 87.1 \\
\hline 16 & CONTINENTAL & AVDS1790-2DR & M88A1 recovery vehicle & 1,799 & $3,196,994$ & 1.2 & 88.3 \\
\hline 17 & HERCULES ENGINE & D298ERX37 & 30-kW generator & 1,089 & $2,928,512$ & 1.1 & 89.4 \\
\hline 18 & CONTINENTAL & LD465-1 & M35A2 2.5-ton truck & 7,798 & $2,388,461$ & 0.9 & 90.4 \\
\hline 19 & ONAN DIV & DN4M1 & 10-kW generator & 2,977 & $2,209,545$ & 0.9 & 91.2 \\
\hline 20 & JOHN DEERE & 6059T & Truck forklift & 2,291 & $2,093,352$ & 0.8 & 92.0 \\
\hline
\end{tabular}

Since the activity information in the database includes FY2001-2003, the data might reflect changes in equipment usage that occurred within DoD over that time period. To illustrate that change, the Engine Fuel Consumption report was run for both the Army and USMC but only for FY2003. Table 11 shows these results. The order of the top six engines remained the same in Table 11 as it was in Table 10, and the total fuel consumption for these six engines accounted for almost the same percentage of consumption. The engine that showed the largest increase in fuel consumption was the Caterpillar 3126B. This increase is due to the increased deployment and usage of the Stryker vehicle between FY2001 and FY2003. Engines employed in generator sets also showed increases over this time period as the 
engines powering $10-\mathrm{kW}, 30-\mathrm{kW}$, and $60-\mathrm{kW}$ generator sets all had larger inventories and fuel consumptions. Engines showing marked decreases included the Cummins Engine VT 400, which powers the USMC AAV, the Cummins Engine NTC 400, which powers Army 10 ton trucks, and the John Deere 6466 6.8L, which powers a USMC tractor/loader.

Table 11. Top 20 Army and USMC off-road diesel engine fuel consumptions for FY2003.

\begin{tabular}{|c|c|c|c|c|c|c|c|}
\hline Rank & Manufacturer & Model & $\begin{array}{l}\text { Representative } \\
\text { Equipment }\end{array}$ & $\begin{array}{l}\text { Average } \\
\text { Inventory }\end{array}$ & Fuel Usage & $\begin{array}{l}\text { Percent } \\
\text { of Total }\end{array}$ & $\begin{array}{l}\text { Running } \\
\text { Total (\%) }\end{array}$ \\
\hline 1 & GENERAL MOTORS & $6.2 \mathrm{~L}$ & HMMWV & 94,928 & $14,743,248$ & 17.3 & 17.3 \\
\hline 2 & ALLIED SIGNAL & AGT 1500 & M1A1, M1A2 & 4,973 & $14,129,437$ & 16.5 & 33.8 \\
\hline 3 & DETROIT DIESEL & $8 \mathrm{~V} 92 \mathrm{TA}$ & HEMTT & 12,693 & $10,223,560$ & 12.0 & 45.8 \\
\hline 4 & CUMMINS ENGINE & NHC 250 & 5 -ton truck & 23,525 & $7,112,306$ & 8.3 & 54.1 \\
\hline 5 & DETROIT DIESEL & $6 \mathrm{~V} 53 \mathrm{~T}$ & LAV, APC & 5,451 & $4,812,455$ & 5.6 & 59.7 \\
\hline 6 & CUMMINS ENGINE & 6CTA8.3 & 5-ton truck & 12,142 & $4,409,017$ & 5.2 & 64.9 \\
\hline 7 & CATERPILLAR & $3126 \mathrm{~B}$ & Stryker, FMTV & 5,017 & $3,822,348$ & 4.5 & 69.3 \\
\hline 8 & CATERPILLAR & 3116 ATAAC & FMTV & 11,952 & $3,536,020$ & 4.1 & 73.5 \\
\hline 9 & CUMMINS ENGINE & VTA-903T & M2A2, M3A2 & 3,493 & $2,566,129$ & 3.0 & 76.5 \\
\hline 10 & ALLIS CHALMERS & 3500 & $60-\mathrm{kW}$ generator & 1,215 & $2,554,053$ & 3.0 & 79.5 \\
\hline 11 & DETROIT DIESEL & $8 V-92$ & MK48 LVS & 1,298 & $2,175,720$ & 2.5 & 82.0 \\
\hline 12 & CUMMINS ENGINE & VT400 & AAV & 1,161 & $2,167,047$ & 2.5 & 84.6 \\
\hline 13 & CUMMINS ENGINE & NTC 400 & 10-ton tractor & 3,820 & $1,893,010$ & 2.2 & 86.8 \\
\hline 14 & HERCULES ENGINE & D298ERX37 & 30-kW generator & 1,439 & $1,127,779$ & 1.3 & 88.1 \\
\hline 15 & CONTINENTAL & LDS465-1 & M35A2, 2.5 ton truck & 10,036 & $1,018,161$ & 1.2 & 89.3 \\
\hline 16 & ONAN DIV & DN4M1 & 10-kW generator & 3,864 & $1,004,081$ & 1.2 & 90.5 \\
\hline 17 & CONTINENTAL & AVDS1790-2DR & M88A1 recovery vehicle & 1,889 & 899,277 & 1.1 & 91.5 \\
\hline 18 & GENERAL MOTORS & $6.5 \mathrm{~L}$ & Heavy HMMWV & 5,701 & 823,044 & 1.0 & 92.5 \\
\hline 19 & JOHN DEERE & $6059 T$ & Truck forklift & 2,453 & 660,040 & 0.8 & 93.2 \\
\hline 20 & DETROIT DIESEL & DDEC \| & 20-ton truck & 1,375 & 618,550 & 0.7 & 94.0 \\
\hline
\end{tabular}

The Engine Fuel Consumption report can also illustrate differences and similarities between the diesel engine activity in the Army and USMC. Table 12 shows the top ten engines ranked by their fuel consumptions in FY2003 for the Army and Table 13 shows the same information for the USMC. A similarity between the services is that the top ten engines account for a large percentage of the overall fuel usage with overall percentages of 92.9 and 84.5 for the Army and USMC, respectively. The M1 tank, powered by the Allied Signal AGT 1500 turbine engine, accounts for the second highest percentage of fuel usage for both services. One difference between the services is the larger amount of overall fuel usage by the Army. Table 12 reports 
individual fuel usages that correspond to a total fuel usage of about 61 million gallons for the Army; while, the individual fuel usages shown in Table 13 corresponds to a total fuel usage of 25 million gallons for the USMC. The tables also indicate a larger reliance on trucks for the Army with their engines accounting for 42.8 percent of overall fuel consumption in Table 12. Table 13 also lists three generator sets in the top ten, and the Army fuel usage list may have shown similar activity if the fuel usage information for this type of equipment was reported correctly in OSMIS.

Table 12. Top 10 Army off-road diesel engine fuel consumptions for FY2003.

\begin{tabular}{|c|l|l|l|c|c|c|c|}
\hline Rank & \multicolumn{1}{|c|}{ Manufacturer } & \multicolumn{1}{|c|}{ Model } & \multicolumn{1}{|c|}{$\begin{array}{c}\text { Representative } \\
\text { Equipment }\end{array}$} & $\begin{array}{c}\text { Average } \\
\text { Inventory }\end{array}$ & $\begin{array}{c}\text { Fuel Usage } \\
\text { (gallons) }\end{array}$ & $\begin{array}{c}\text { Percent of } \\
\text { Total }\end{array}$ & $\begin{array}{c}\text { Running } \\
\text { Total (\%) }\end{array}$ \\
\hline 1 & GENERAL MOTORS & $6.2 \mathrm{~L}$ & HMMWV & 82,877 & $13,004,748$ & 21.4 & 21.4 \\
\hline 2 & ALLIED SIGNAL & AGT 1500 & M1A1, M1A2 & 4,570 & $11,023,169$ & 18.1 & 39.5 \\
\hline 3 & DETROIT DIESEL & 8V92TA & HEMTT & 12,693 & $10,223,560$ & 16.8 & 56.4 \\
\hline 4 & CUMMINS ENGINE & NHC 250 & 5 -ton truck & 17,521 & $4,939,199$ & 8.1 & 64.5 \\
\hline 5 & CUMMINS ENGINE & 6CTA8.3 & 5-ton truck & 12,142 & $4,409,017$ & 7.3 & 71.7 \\
\hline 6 & CATERPILLAR & $3126 B$ & Stryker, FMTV & 5,017 & $3,822,348$ & 6.3 & 78.0 \\
\hline 7 & CATERPILLAR & 3116 ATAAC & FMTV & 11,952 & $3,536,020$ & 5.8 & 83.8 \\
\hline 8 & CUMMINS ENGINE & VTA-903T & M2A2, M3A2 & 3,493 & $2,566,129$ & 4.2 & 88.1 \\
\hline 9 & CUMMINS ENGINE & NTC 400 & 10 -ton tractor & 3,820 & $1,893,010$ & 3.1 & 91.2 \\
\hline 10 & CONTINENTAL & LDS465-1 & M35A2, 2.5-ton truck & 10,036 & $1,018,161$ & 1.7 & 92.9 \\
\hline
\end{tabular}

Table 13. Top 10 USMC off-road diesel engine fuel consumptions for FY2003.

\begin{tabular}{|c|l|l|l|c|c|c|c|}
\hline Rank & \multicolumn{1}{|c|}{ Manufacturer } & \multicolumn{1}{|c|}{ Model } & \multicolumn{1}{|c|}{$\begin{array}{c}\text { Representative } \\
\text { Equipment }\end{array}$} & $\begin{array}{c}\text { Average } \\
\text { Inventory }\end{array}$ & $\begin{array}{c}\text { Fuel Usage } \\
\text { (gallons) }\end{array}$ & $\begin{array}{c}\text { Percent of } \\
\text { Total }\end{array}$ & $\begin{array}{c}\text { Running } \\
\text { Total (\%) }\end{array}$ \\
\hline 1 & DETROIT DIESEL & 6 V53T & LAV & 679 & $4,153,055$ & 16.8 & 16.8 \\
\hline 2 & ALLIED SIGNAL & AGT 1500 & M1A1, M1A2 & 403 & $3,106,268$ & 12.6 & 29.4 \\
\hline 3 & ALLIS CHALMERS & 3500 & $60-k W$ generator & 609 & $2,553,774$ & 10.4 & 39.8 \\
\hline 4 & DETROIT DIESEL & 8 V-92 & 5-ton truck, MK48 LVS & 1,298 & $2,175,720$ & 8.8 & 48.6 \\
\hline 5 & CUMMINS ENGINE & NHC 250 & 5-ton truck, M923A1 & 6,004 & $2,173,107$ & 8.8 & 57.4 \\
\hline 6 & CUMMINS ENGINE & VT400 & AAV & 1,161 & $2,167,047$ & 8.8 & 66.2 \\
\hline 7 & GENERAL MOTORS & 6.2 L & HMMWV & 12,051 & $1,738,500$ & 7.0 & 73.2 \\
\hline 8 & HERCULES ENGINE & D298ERX37 & 30-kW generator & 1,010 & $1,127,608$ & 4.6 & 77.8 \\
\hline 9 & ONAN DIV & DN4M1 & 10-kW Generator & 1,343 & $1,004,037$ & 4.1 & 81.9 \\
\hline 10 & JOHN DEERE & $6059 T$ & $\begin{array}{l}\text { Truck forklift, } 60-k W \\
\text { generator }\end{array}$ & 613 & 659,871 & 2.7 & 84.5 \\
\hline
\end{tabular}




\section{Fuel Consumption Comparison with HQRADDS}

HQRADDS is a database of fossil fuel use within the Army. DUERS applies only to the Army-wide database maintained at the Assistant Chief of Staff Installation Management System (ACSIM) and is accessed by authorized users of the Army energy program. Authorized users can access HQRADDS at:

https://hqradds.hqda.pentagon.mil/index1.html.

At one of this project's review presentations, it was suggested that a comparison be made between the fuel usage information generated from OSMIS and the information contained in HQRADDS. It was believed that this type of comparison would provide a validation of OSMIS fuel consumption data which, as was mentioned in Chapter 2, are not reported directly to OSMIS but are calculated from activity information and the expected fuel consumption rate.

Unfortunately, the comparison between the two systems is not exact or straightforward. One difference is that HQRADDS reports fuel usage based on what installations purchase and use at their locations while OSMIS fuel usage is based on an installation's activity information, regardless of where it is used. Another difference is that the mobility fuel usage reported in HQRADDS includes aviation systems that were not included in the diesel-powered off-road equipment activity database developed during this project. A final difference, described in Chapter 2, is the OSMIS problem of incorrectly reporting the activity of non-aviation-related equipment, for which activity is reported in hours.

A major problem was discovered with HQRADDS when mobility fuel usage reports were generated. Many of the top fuel-consuming installations from the OSMIS data did not show any usage in HQRADDS. Figure 30 is the Installation Fuel Consumption report for the Army in FY2003 showing installation fuel consumption data from OSMIS. The top six installations on this report did not show any mobility fuel consumption in HQRADDS for FY2001-2003 when these installations obviously used large amounts of fuel in their vehicles during this time period. For this reason, it was impossible to do a broad-based comparison of Major Army Commands. Instead, comparisons were done for installations that did show usage in both HQRADDS and OSMIS. 
Fuel Consumption and Inventory Summary by Installation

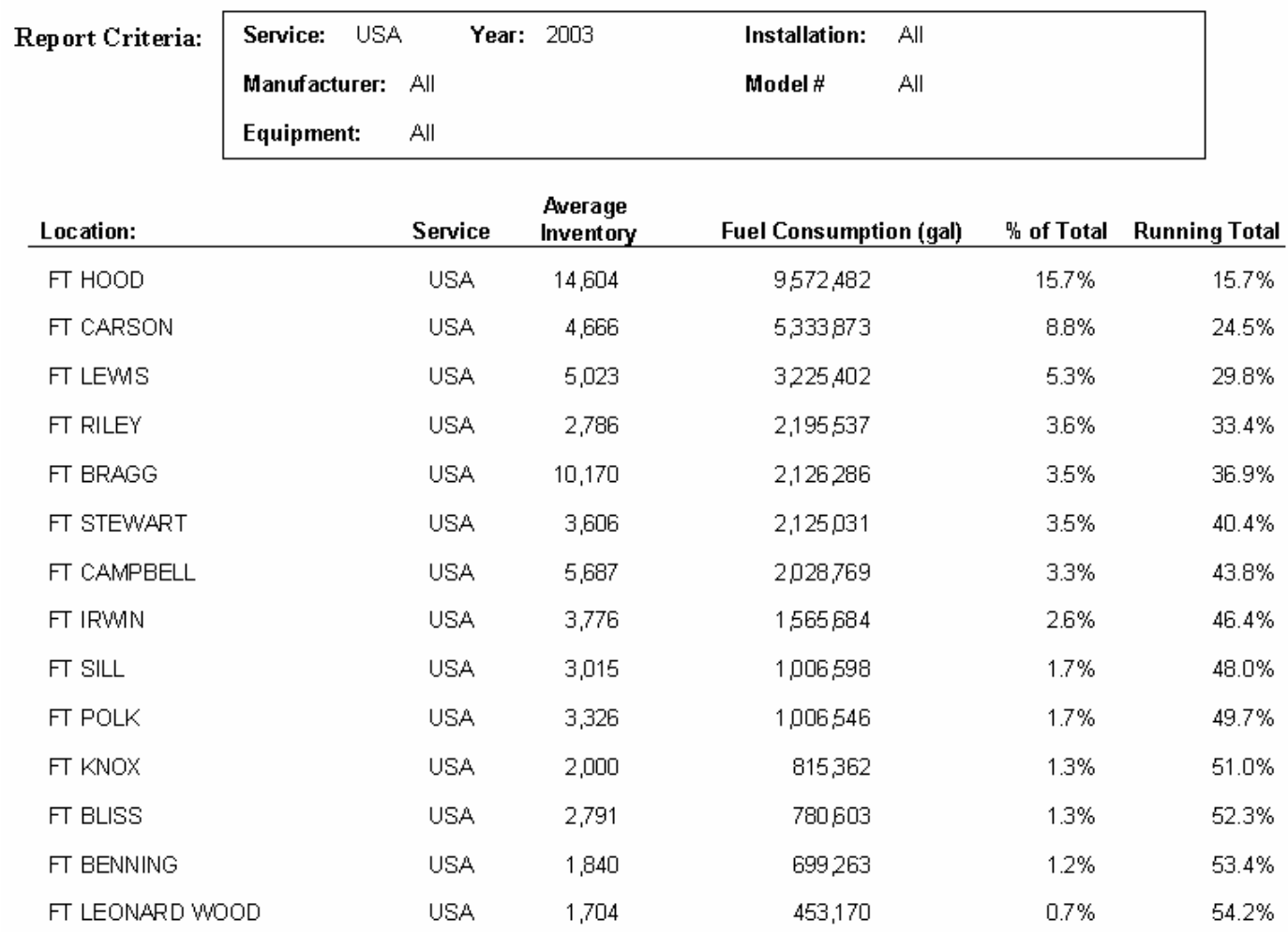

Figure 30. Installation fuel consumption in FY2003.

HQRADDS Annual Mobility reports were generated for Forts Campbell, Irwin, Sill, Polk, Knox, and Benning. These installations had the largest fuel consumptions in OSMIS from FY 2001-2003 and, in HQRADDS, also had reported fuel usage. Reports were also generated from HQRADDS that showed the type of petroleum product consumed for mobility purposes. With one exception, the installations all reported a much larger consumption of JP8 compared with diesel or gasoline. The exception to this consumption was Fort Polk, which reported larger usage of gasoline than JP8 and less overall usage than might have been expected from the OSMIS results. Since Fort Polk's data were not consistent with the other installations' data, it was not part of the comparison.

To achieve a better comparison, OSMIS fuel consumption reports for aviation systems were run for each of the installations being compared. The fuel consumptions were totaled from these reports and added to the fuel consumption reported in the installation fuel consumption report shown in Figure 30. HQRADDS reports fuel consumption in million British thermal units (MBtus), which was converted to gallons (gal) by assuming a heat content of $5.67 \mathrm{MBtu} / \mathrm{barrel}$ and $42 \mathrm{gal} / \mathrm{barrel}$. Table 14 shows the results of this comparison. Most of the fuel consumption reported by OSMIS is lower than the HQRADDS data. This would be expected both because 
OSMIS does not report generator and other nonvehicular equipment activity correctly and because many major training facilities purchase fuel used by equipment that belongs to visiting units using the training facilities. A conspicuous exception to this trend is the fuel usage information for Fort Campbell in FY2003, which showed a dramatic increase in usage in OSMIS and a dramatic decrease in usage in HQRADDS. Most of the usage data were in general agreement with each other and HQRADDS values were usually no more than twice the amount reported by OSMIS.

Table 14. Installation fuel usage in gallons as reported in OSMIS and HQRADDS.

\begin{tabular}{|c|c|c|c|}
\hline & FY 2001 & FY 2002 & FY 2003 \\
\hline \multicolumn{4}{|l|}{ Fort Campbell } \\
\hline OSMIS aviation & $7,019,000$ & $8,322,897$ & $14,100,163$ \\
\hline OSMIS off-road & $1,419,316$ & $1,156,600$ & $2,028,769$ \\
\hline OSMIS total & $8,438,316$ & $9,479,497$ & $16,128,932$ \\
\hline HQRADDS total mobility & $11,525,111$ & $12,853,519$ & $7,960,770$ \\
\hline \multicolumn{4}{|l|}{ Fort Irwin } \\
\hline OSMIS aviation & 480,832 & 587,172 & 629,282 \\
\hline OSMIS off-road & $3,314,238$ & $2,013,449$ & $1,565,684$ \\
\hline OSMIS total & $3,795,070$ & $2,600,621$ & $2,194,966$ \\
\hline HQRADDS total mobility & $5,712,970$ & $5,529,059$ & $3,785,615$ \\
\hline \multicolumn{4}{|l|}{ Fort Benning } \\
\hline OSMIS aviation & 331,049 & 591,795 & 363,130 \\
\hline OSMIS off-road & $1,067,990$ & 575,028 & 699,263 \\
\hline OSMIS total & $1,399,039$ & $1,166,823$ & $1,062,393$ \\
\hline HQRADDS total mobility & $1,895,793$ & $1,243,244$ & $1,500,193$ \\
\hline \multicolumn{4}{|l|}{ Fort Knox } \\
\hline OSMIS aviation & 275,321 & 274,944 & 0 \\
\hline OSMIS off-road & 865,137 & 797,607 & 815,362 \\
\hline OSMIS total & $1,140,458$ & $1,072,551$ & 815,362 \\
\hline HQRADDS total mobility & $2,036,200$ & $1,889,770$ & $2,162,289$ \\
\hline \multicolumn{4}{|l|}{ Fort Sill } \\
\hline OSMIS aviation & NR & NR & NR \\
\hline OSMIS off-road & 863,823 & 908,681 & $1,006,598$ \\
\hline OSMIS total & 863,823 & 908,681 & $1,006,598$ \\
\hline HQRADDS total mobility & $1,207,237$ & $1,445,733$ & $1,257,074$ \\
\hline
\end{tabular}

NR - Not reported

\section{Summary}

The fuel consumption information for diesel engines used in Army and USMC offroad equipment provided useful information for developing an emission testing priority. Although there are more than 800 equipment items for the Army and USMC in the database, there are fewer than 200 engines used in this equipment. The data 
analysis showed that the top ten most frequently used engines in the Army and USMC account for a large majority of the fuel usage. It should there-fore be possible to develop engine-specific emission information that can estimate emissions from a large percentage of military equipment.

The fuel usage comparison with HQRADDS was complicated by missing data in the HQRADDS system. However, a comparison with installations showing fuel usage in both OSMIS and HQRADDS provides some evidence that the OSMIS information is accurate. 


\section{Summary and Conclusions}

The database for diesel-powered off-road equipment was prepared to allow researchers working on SERDP project WP-1336 to select and prioritize the equipment to be tested for air pollution emissions and to be a source of information for their engine emission estimation tool. The database has proved useful as a prioritization tool. The database contains activity information for all the military off-road equipment used by the Army and USMC, which represents the large majority of the DoD's off-road equipment. The database provides a link between the large population of specific equipment items and the much smaller population of diesel engines that power this equipment. Table 11 provides useful information for prioritizing DoD usage of off-road equipment. For vehicles, the HMMWV, HEMTT, 5-ton trucks, LAV, Stryker, FMTV, and the Bradley Fighting Vehicle all show up as important engine emission sources. M1A1 and M1A2 tanks are also large sources but are powered by a turbine engine that would probably not be classified as a diesel offroad source. Although generators are not listed as prominently in Table 11, they are artificially underrepresented because Army generator usage is not reported correctly in OSMIS. The data from the USMC portion of the Navy VAMOSC system indicate that $60-\mathrm{kW}, 30-\mathrm{kW}$, and $10-\mathrm{kW}$ generator sets are major engine emission sources and it is very likely that a similar level of usage occurs within the Army and throughout DoD.

The database will also be useful for the engine emission estimation tool being developed under WP-1336. The engine emission factors developed from WP-1336 will require data on equipment characteristics such as engine power and equipment usage such as vehicle miles traveled, hours of operation, or fuel consumption in order to estimate emissions. The database developed under this project will serve as the source of much of this required data.

Because of the user interface, the database will also be useful to a wider population not necessarily familiar with databases or MS Access. The interface allows users to view, find, sort, and filter data from all the database tables and analyze data through reports based upon user-provided criteria. The interface allows database access to anyone interested in obtaining or analyzing data about DoD fuels, off-road equipment, diesel engines, and off-road equipment usage. The database, the interface, and this report will be made available to anyone with DoD menu privileges in the permanent shared file library section of the DENIX website. 


\section{References}

Clark, N., J. Kern, C. Atkinson, and R. Nine, Factors Affecting Heavy Duty Diesel Vehicle Emissions, Journal of the Air and Waste Management Association, January 2002, 52:8494.

Craig Harvey C., P. Carey, and J. Warila,, "EPA's Newest Draft Nonroad Emission Inventory Model," presented at the 12th International Emission Inventory Conference, San Diego, California, April 28-May 1, 2003.

Dickson, C. L., “Aviation Turbine Fuels, 1998," TRW Petroleum Technologies Report No. 209 TRW209 PPS 99/2, March 1999.

“Aviation Turbine Fuels, 2002," Northrop Grumman Mission Systems Report No. 229 NGMS-229 PPS 2003/2, April 2003.

"Diesel Fuel Oils 2003," Northrop Grumman Mission Systems Report No. 232 NGMS-232 PPS 2003/5, January 2004.

. "Diesel Fuel Oils, 2001," TRW Petroleum Technologies Report No. 222 TRW-222 PPS 2001/5, November 2001.

. “Motor Gasolines, Summer 1998," TRW Petroleum Technologies Report No. 208 TRW-208 PPS 99/1, February 1999

"Motor Gasolines, Summer 2002," Northrop Grumman Mission Systems Report No. 228 NGMS-228 PPS 2003/1, March 2003.

. "Motor Gasolines, Winter 1998-99," TRW Petroleum Technologies Report No. 210 TRW210 PPS 99/3, July 1999

"Motor Gasolines, Winter 2002-03," Northrop Grumman Mission Systems Report No. 230 NGMS-230 PPS 2003/3, August 2003.

U.S. Environmental Protection Agency (EPA), 1998. Exhaust Emission Factors for Nonroad Engine Modeling--Compression-Ignition, Report No. NR-009A, June 1998.

2000. Reducing Air Pollution from Nonroad Engines, EPA420-F-00-048, November 2000.

. 2001. Control of Emissions of Hazardous Air Pollutants from Mobile Sources (40 CFR Parts 80 and 86); Federal Register, 2001, 66 (61), 17229-17273.

IBM, Naval Visibility and Management of Operating and Support Costs (VAMOSC) 3.3, USMC Ground Equipment User Manual, 30 September 2004 
Intellimotive Environmental Systems, "Robins AGE with Motor.xls," developed for Warner Robins Air Logistics Center, Support Equipment and Vehicle Directorate, received from Ann Smith 10-17-2002.

Kemme, M.R. and E.A. Frame, Tailpipe Emission Estimations for Army Off-Road Sources, Air and Waste Management Association 97th Annual Conference and Exhibition in Minneapolis, MN, June 21-24, 2005.

Montalvo D.A. and T.L. Ullman, "Heavy-Duty Emissions Using California Reference Fuel and Military Grade JP-8," ASME Paper 93-ICE-31, presented at the Energy-Sources Technology Conference and Exhibition, Houston, Texas, January 31-February 4, 1993.

Naval Cost Analysis Division (FMB-6), Visibility and Management of Operating and Support Costs (VAMOSC) system, Copyrighted (C 2000/2003, Available at http://www.navyvamosc.com/.

Naval Cost Analysis Division, FMB-6, "Naval VAMOSC Overview, August 2004”, Available at: http://www.navyvamosc.com/docs/VAMOSC_Overview_August_2004.ppt

Office of the Deputy Under Secretary of Defense (Installations \& Environment), Base Structure Report (A Summary of DoD's Real Property Inventory), Fiscal Year 2002 Baseline.

Resolution 98-35: Identification of Particulate Emissions from Diesel-Fueled Engines as a Toxic Air Contaminate; California Air Resources Board: Sacramento , CA, 1998.

SB 700-20, Army Adopted/Other Items Selected for Authorization/List of Reportable Items, Logistics Supply Agency, effective 1 December 2003.

SB 710-2, Department of the Army Supply Bulletin, Supply Control Combat Consumption Rates for Ground and Aviation Type Petroleum Products, Army Petroleum Center, 12 December 2002.

TARDEC, "Listing of U.S. Army Fuel-Consuming Mobility \& Combat Support Equipment," Special Bulletin, compiled by U.S. Army TARDEC Fuels and Lubricants Research Facility, SwRI, San Antonio, TX, for U.S. Army TARDEC, Fuels and Lubricants Business Area, Warren MI, contract no. DAAK70-92-C-0059, 1996.

Yost, D., Montalvo, D., Frame, E., SAE Paper 961981 "U.S. Army Investigation of Diesel Exhaust Emissions Using Fuels with Varying Sulfur Content,” October 1996. 


\section{Appendix: Engine Fuel Consumption With Equipment List Reports for All Services With Equipment Usage in FY2003}

\section{Fuel Consumption and Inventory Summary by Engine Model}

\begin{tabular}{|c|c|c|c|c|c|}
\hline Report Criteria: & Service: All & 2003 & Installation: All & & \\
\hline Manufacturer & Model & $\begin{array}{l}\text { Average } \\
\text { Inventory }\end{array}$ & Fuel Consumption & $\%$ of Total & Running \% \\
\hline GENERAL MOTORS & $6.2 \mathrm{~L}$ & 94,928 & $14,743,248$ & $17.3 \%$ & $17.3 \%$ \\
\hline ALLIED SIGNAL & AGT 1500 & 4,973 & $14,129,437$ & $16.5 \%$ & $33.8 \%$ \\
\hline DETROIT DIESEL & 8V92TA & 12,693 & $10,223,560$ & $12.0 \%$ & $45.8 \%$ \\
\hline CUMMINS ENGINE & NHC 250 & 23,525 & $7,112,306$ & $8.3 \%$ & $54.1 \%$ \\
\hline DETROIT DIESEL & 6V53T & 5,451 & $4,812,455$ & $5.6 \%$ & $59.7 \%$ \\
\hline CUMMINS ENGINE & 6CTA8.3 & 12,142 & $4,409,017$ & $5.2 \%$ & $64.9 \%$ \\
\hline CATERPILLAR & $3126 B$ & 5,017 & $3,822,348$ & $4.5 \%$ & $69.3 \%$ \\
\hline CATERPILLAR & 3116 ATAAC & 11,952 & $3,536,020$ & $4.1 \%$ & $73.5 \%$ \\
\hline CUMMINS ENGINE & VTA-903T & 3,493 & $2,566,129$ & $3.0 \%$ & $76.5 \%$ \\
\hline ALLIS CHALMERS & 3500 & 1,215 & $2,554,053$ & $3.0 \%$ & $79.5 \%$ \\
\hline DETROIT DIESEL & $8 V-92$ & 1,298 & $2,175,720$ & $2.5 \%$ & $82.0 \%$ \\
\hline CUMMINS ENGINE & VT400 & 1,161 & $2,167,047$ & $2.5 \%$ & $84.6 \%$ \\
\hline CUMMINS ENGINE & NTC 400 & 3,820 & $1,893,010$ & $2.2 \%$ & $86.8 \%$ \\
\hline HERCULES ENGINE & D298ERX37 & 1,439 & $1,127,779$ & $1.3 \%$ & $88.1 \%$ \\
\hline CONTINENTAL & LDS465-1 & 10,036 & $1,018,161$ & $1.2 \%$ & $89.3 \%$ \\
\hline ONAN DIV & DN4M1 & 3,864 & $1,004,081$ & $1.2 \%$ & $90.5 \%$ \\
\hline CONTINENTAL & AVDS1790-2DR & 1,889 & 899,277 & $1.1 \%$ & $91.5 \%$ \\
\hline GENERAL MOTORS & $6.5 \mathrm{~L}$ & 5,701 & 823,044 & $1.0 \%$ & $92.5 \%$ \\
\hline JOHN DEERE & $6059 T$ & 2,453 & 660,040 & $0.8 \%$ & $93.2 \%$ \\
\hline DETROIT DIESEL & DDEC II & 1,375 & 618,550 & $0.7 \%$ & $94.0 \%$ \\
\hline JOHN DEERE & $64666.8 \mathrm{~L}$ & 499 & 615,823 & $0.7 \%$ & $94.7 \%$ \\
\hline CONTINENTAL & LD465-1 & 6,278 & 610,581 & $0.7 \%$ & $95.4 \%$ \\
\hline DETROIT DIESEL & $6 \mathrm{~V} 53$ & 8,420 & 442,514 & $0.5 \%$ & $95.9 \%$ \\
\hline CUMMINS ENGINE & V903C & 408 & 429,250 & $0.5 \%$ & $96.4 \%$ \\
\hline MERCEDES BENZ & OM 352 & 1,901 & 409,317 & $0.5 \%$ & $96.9 \%$ \\
\hline CATERPILLAR & 3306 & 278 & 400,886 & $0.5 \%$ & $97.4 \%$ \\
\hline CATERPILLAR & 3208 & 126 & 321,888 & $0.4 \%$ & $97.7 \%$ \\
\hline JI CASE & G188D & 152 & 285,250 & $0.3 \%$ & $98.1 \%$ \\
\hline DETROIT DIESEL & $8 \mathrm{~V} 71 \mathrm{~T}$ & 1,592 & 278,067 & $0.3 \%$ & $98.4 \%$ \\
\hline ONAN DIV & Q106M & 3,737 & 241,344 & $0.3 \%$ & $98.7 \%$ \\
\hline PERKINS & 704-30T & 431 & 206,630 & $0.2 \%$ & $98.9 \%$ \\
\hline CATERPILLAR & 3304 & 1,590 & 199,456 & $0.2 \%$ & $99.2 \%$ \\
\hline
\end{tabular}


Manufacturer

CATERPILLAR

CONTINENTAL

JOHN DEERE

CONTINENTAL

CUMMINS ENGINE

JI CASE

MERCEDES BENZ

CATERPILLAR

MERCEDES BENZ

DEUTZ

ONAN DIV

YORK SHIPLEY

CUMMINS ENGINE

CATERPILLAR

DETROIT DIESEL

CATERPILLAR

JI CASE

DETROIT DIESEL

CATERPILLAR

ONAN DIV

CONTINENTAL

CATERPILLAR

HERCULES ENGINE

ISUZU

CATERPILLAR

INTER HARV

CUMMINS ENGINE

DETROIT DIESEL

CUMMINS ENGINE

ONAN DIV

CATERPILLAR

CONTINENTAL

ONAN DIV

CATERPILLAR

YANMAR

CATERPILLAR

\section{Model}

3408T

AVDS1790-2DA

4039T

AVDS1790-2D

4B3.9

6T590

OM 603-950

3406

OM402AT

F4L-912

DJC-12315T

VY-7-8DD

6BT5.9-C

3306 T

$453 \mathrm{~N}$

D342

504BD

6V92TC/6-71

D333CT

DJC99E/9487

AVDS1790-2C

C240

D198ERX51

C240

3046T

DT-817C

6BT5.9

4-71

V8 2652380

DN2M

3126 HEUI

AVDS1790-2A, D,

Q106D

3208 V8

L70A-D/DE

D333C (T)
Average

Inventory

421

24

795

415

2,385

76

501

907

70

50

308

192

1,437

888

346

167

1,000

9

1,183

1,486

7

870

949

1,416

55

59

1,262

6

24

3,761

242

2

3,989

12

11

0
Fuel Consumption

160,027

125,688

109,676

105,966

72,946

37,084

35,841

28,081

23,293

8,279

5,487

1,226

325

309

294

227

166

144

126

123

119

84

77

76

67

67

52

21

14

12

9

4

3

2

0
$\%$ o$$
0.2 \%
$$

$0.1 \%$

$0.1 \%$

$0.1 \%$

$0.1 \%$

$0.0 \%$

$0.0 \%$

$0.0 \%$

$0.0 \%$

$0.0 \%$

$0.0 \%$

$0.0 \%$

$0.0 \%$

$0.0 \%$

$0.0 \%$

$0.0 \%$

$0.0 \%$

$0.0 \%$

$0.0 \%$

$0.0 \%$

$0.0 \%$

$0.0 \%$

$0.0 \%$

$0.0 \%$

$0.0 \%$

$0.0 \%$

$0.0 \%$

$0.0 \%$

$0.0 \%$

$0.0 \%$

$0.0 \%$

$0.0 \%$

$0.0 \%$

$0.0 \%$

$0.0 \%$
Running \%

$99.3 \%$

$99.5 \%$

$99.6 \%$

$99.7 \%$

$99.8 \%$

$99.9 \%$

$99.9 \%$

$100.0 \%$

$100.0 \%$

$100.0 \%$

$100.0 \%$

$100.0 \%$

$100.0 \%$

$100.0 \%$

$100.0 \%$

$100.0 \%$

$100.0 \%$

$100.0 \%$

$100.0 \%$

$100.0 \%$

$100.0 \%$

$100.0 \%$

$100.0 \%$

$100.0 \%$

$100.0 \%$

$100.0 \%$

$100.0 \%$

$100.0 \%$

$100.0 \%$

$100.0 \%$

$100.0 \%$

$100.0 \%$

$100.0 \%$

$100.0 \%$

$100.0 \%$

$100.0 \%$ 


\section{Fuel Consumption, Activity, and Inventory for Engines and Equipment}

Report Criteria: Year: 2003

Manufacturer: All

Manufacturer

Model

GENERAL MOTORS

$6.2 L$

Equipment using this Engine

Nomenclature

TRUCK UTIL TROOP/CGO HMMWV M998

TRUCK UTIL ARMT CARR ARMORED HMMWV M1025

TRUCK UTIL TROOP/CGO HMMWV M998A1

AN/TWQ-1 - Avenger

TRUCK UTIL TACTICAL CUCV M1009

TRUCK UTIL TROOP/CGO HMMWV M1038

TRK CARGO, HMMWV M998/1038

TRUCK UTIL HVY VARIANT HMMWV M1097

TRUCK UTIL ARMT CARR ARMORED HMMWV M1026

TRUCK UTIL TOW CARRIER ARMORED HMMWV M966

TRUCK CARGO TAC CUCV M1008

TRUCK AMBULANCE 4LTR HMMWV M997

TRUCK UTIL S250 SHELTER HMMWV M1037

TRUCK CARGO TAC CUCV M1008A1

TRUCK TAC SHELTER CUCV M1028

Radio Set, AN/MRC-145A

TRUCK ARMT HMMWV M1043/1044

TRUCK HMMWV TOW CARR M1045/10

TRUCK AMBULANCE 2LTR HMMWV M996

TRUCK UTILITY SHELTER M1037

TRUCK AMBULANCE 4LTR HMMWV M997

TRUCK TAC SHELTER CUCV M1028A1

TRUCK AMB SOFT TOP HMMWV, M10

Radio Terminal Set, AN/MRC-142

TRUCK AMBULANCE: TACTICAL 5/4 TON 4X4 M1010

TRUCK UTIL HVY VARIANT HMMWV M1097

TRUCK AMBULANCE 4LTR HMMWV M997A1

TRUCK UTIL TROOP/CGO HMMWV M1038A1

TRUCK UTIL ARMT CARR ARMORED HMMWV M1025A1
Service: All

Installation: All

Model \#: All

Average Inventory

94,928

Service

USA

USA

USA

USMC

USA

USA

USMC

USA

USA

USA

USA

USA

USA

USA

USA

USMC

USMC

USMC

USA

USMC

USMC

USA

USMC

USMC

USA

USMC

USA

USA

USA

$6,786,528$

987,357

939,319

856,541

848,751

\author{
Fuel Consumption \\ $14,743,248$
}
$\%$ of Total
$17.3 \%$

Running

Total

$17.3 \%$

Fuel Usage
(gal)

Activity

Inventory

$100,666,834$ miles

41,752

$14,645,802$ miles

5,782

5,668

$13,933,233$ miles

77,837 hours

213

4,631

4,140

7,634

2,527

2,268

2,045

2,605

2,755

5,048

1,880

1,236

1,196

1,158

603

277

194

425

133

253

355

70

20

11

16

25 


\begin{tabular}{|c|c|c|c|c|c|}
\hline Nomenclature & Service & $\begin{array}{l}\text { Fuel Usage } \\
\text { (gal) }\end{array}$ & Activity & & Inventory \\
\hline TRUCK UTIL ARMT CARR ARMORED HMMWV M1026 & A1 USA & 124 & 1,832 & miles & 5 \\
\hline TRUCK AMBULANCE 2LTR HMMWV M996A1 & USA & 86 & 1,283 & miles & 3 \\
\hline Manufacturer & $\begin{array}{l}\text { Average } \\
\text { Inventory }\end{array}$ & Fuel Consumption & \multicolumn{2}{|c|}{$\%$ of Total } & $\begin{array}{l}\text { Running } \\
\text { Total }\end{array}$ \\
\hline ALLIED SIGNAL & 4,973 & $14,129,437$ & & $16.5 \%$ & $33.8 \%$ \\
\hline \multicolumn{6}{|l|}{ Equipment using this Engine } \\
\hline Nomenclature & Service & $\begin{array}{c}\text { Fuel Usage } \\
\text { (gal) }\end{array}$ & \multicolumn{2}{|l|}{ Activity } & Inventory \\
\hline TANK COMBAT 120MM M1A1 & USA & $5,991,002$ & 778,393 & miles & 3,199 \\
\hline TANK COMBAT 120MM M1A2 & USA & $4,726,652$ & 600,960 & miles & 598 \\
\hline TANK COMBAT FULL TRACKED 120MM M1A1 & USMC & $3,106,268$ & 358,218 & hours & 403 \\
\hline TANK COMBAT 105MM M1IP & USA & 305,515 & 43,645 & miles & 773 \\
\hline Manufacturer & $\begin{array}{l}\text { Average } \\
\text { Inventory }\end{array}$ & Fuel Consumption & \multicolumn{2}{|c|}{$\%$ of Total } & $\begin{array}{l}\text { Running } \\
\text { Total }\end{array}$ \\
\hline DETROIT DIESEL & 12,693 & $10,223,560$ & \multicolumn{2}{|c|}{$12.0 \%$} & $45.8 \%$ \\
\hline \multicolumn{6}{|l|}{ Equipment using this Engine } \\
\hline Nomenclature & Service & $\begin{array}{c}\text { Fuel Usage } \\
\text { (gal) }\end{array}$ & \multicolumn{2}{|l|}{ Activity } & Inventory \\
\hline TRUCK TRACTOR HET M1070 & USA & $1,971,948$ & $5,484,481$ & miles & 2,008 \\
\hline TRUCK TANK FS 2500GL HEMTT M978 & USA & $1,593,120$ & $3,832,100$ & miles & 1,945 \\
\hline TRUCK CARGO 10TON HEMTT M977 & USA & $1,510,790$ & $3,634,062$ & miles & 1,742 \\
\hline TRUCK WRECKER 10TON HEMTT M984A1 & USA & $1,382,979$ & $3,326,625$ & miles & 1,590 \\
\hline TRUCK TANK FS 2500GL HEMTT WW M978 & USA & $1,058,844$ & $2,546,948$ & miles & 1,124 \\
\hline TRUCK CARGO HEAVY PLS TRANS M1074 & USA & 894,569 & $2,151,802$ & miles & 1,252 \\
\hline TRUCK CARGO 10TON HEMTT M985 & USA & 746,071 & $1,794,603$ & miles & 1,198 \\
\hline TRUCK CARGO 10TON HEMTT WW M977 & USA & 405,229 & 974,740 & miles & 639 \\
\hline TRUCK CARGO PALLETALIZED LOAD HNDG M1120 & USA & 273,079 & 656,866 & miles & 284 \\
\hline TRUCK TRACTOR 10TON HEMTT WW M983 & USA & 179,322 & 431,343 & miles & 345 \\
\hline TRUCK CARGO 10TON HEMTT WW M985 & USA & 138,393 & 332,892 & miles & 254 \\
\hline TRUCK TRACTOR HET 22.5 TON WW M911 & USA & 25,869 & 74,268 & miles & 218 \\
\hline TRUCK CARGO 10TON HEMTT M985E1 & USA & 23,079 & 55,515 & miles & 55 \\
\hline TRUCK WRECKER 10TON HEMTT M984 & USA & 20,268 & 48,752 & miles & 39 \\
\hline
\end{tabular}




\section{Manufacturer \\ CUMMINS ENGINE}

\section{Model}

NHC 250

Equipment using this Engine

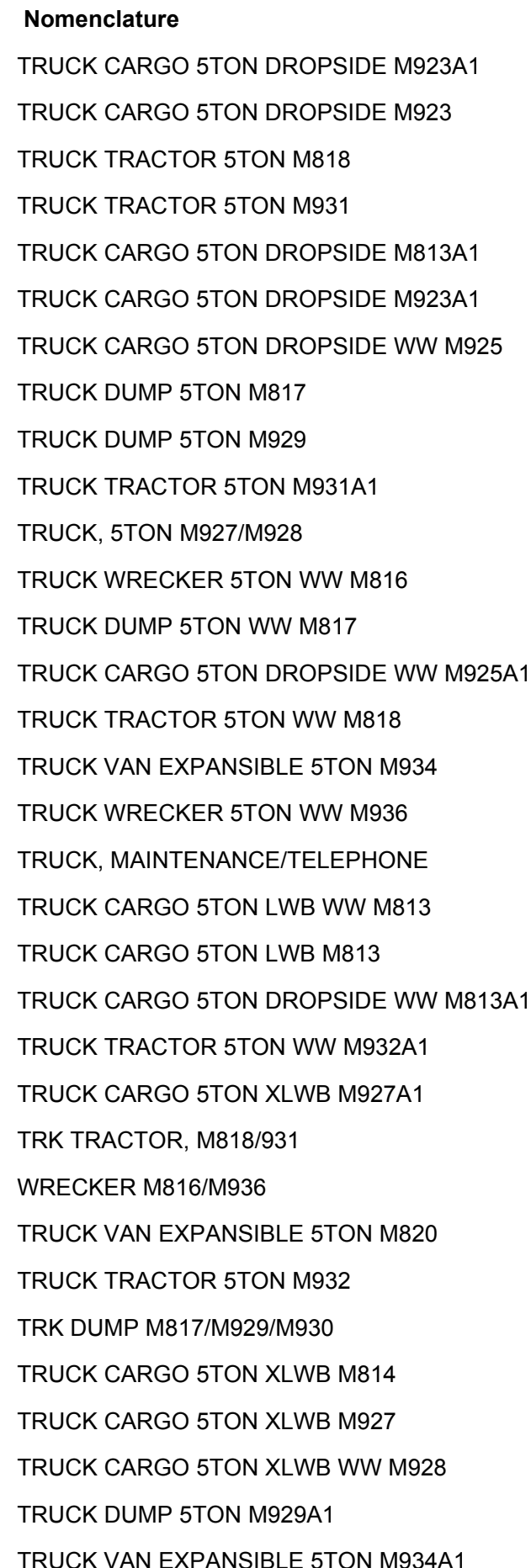

Average Inventory

23,525

Service

USMC

USA

USA

USA

USA

USA

USA

USA

USA

USA

USMC

USA

USA

USA

USA

USA

USA

USMC

USA

USA

USA

USA

USA

USMC

USMC

USA

USA

USMC

USA

USA

USA

USA

USA
Fuel Consumption
$7,112,306$

$\%$ of Total

$8.3 \%$

Total

$54.1 \%$

\begin{tabular}{rrr}
$\begin{array}{c}\text { Fuel Usage } \\
\text { (gal) }\end{array}$ & \multicolumn{1}{c}{ Activity } & Inventory \\
$1,770,496$ & $11,532,135$ miles & 4,481 \\
$1,030,758$ & $5,396,320$ miles & 2,556 \\
745,689 & $2,885,491$ miles & 3,127 \\
412,067 & $2,157,290$ miles & 1,255 \\
297,024 & $1,149,354$ miles & 1,248 \\
249,332 & $1,305,327$ miles & 759 \\
245,067 & $1,282,998$ miles & 922 \\
244,412 & 945,767 miles & 836 \\
234,666 & $1,228,545$ miles & 661 \\
214,718 & $1,124,111$ miles & 623
\end{tabular}

21,461

14,552
623

553

799

450

400

566

331

395

14

298

497

419

93

180

288

233

174

149

435

149

169

85

112,353 miles $\quad 172$

59

22

36

61

3

9

0

1

4

98

19

93

80

33

74

35

69

114,249 miles $\quad 85$

76,186 miles $\quad 90$ 


\section{Nomenclature}

TRUCK VAN EXPANSIBLE 5TON M820A2

TRUCK CARGO 5TON XLWB WW M814

TRUCK CARGO 5TON XLWB WW M928A1

TRUCK WRECKER 5TON WW M936A1

TRUCK DUMP 5TON WW M930

TRUCK VAN EXPANSIBLE 5TON M935A1

TRUCK VAN EXPANSIBLE 5TON M935

TRUCK CARGO 5TON LWB M924

TRUCK TRAC/WRECKER 5TON WW M819

$\begin{array}{lc}\text { Manufacturer } & \text { Model } \\ \text { DETROIT DIESEL } & 6 V 53 T\end{array}$

Equipment using this Engine

Nomenclature
LIGHT ARMORED VEHICLE (25)
LIGHT ARMORED VEHICLE LOGISTICS
LIGHT ARMORED VEHICLE ANTI-TANK
LIGHT ARMORED VEHICLE COMMAND
CARRIER PERSONNEL FT (RISE) M113A3
LIGHT ARMORED VEHICLE MORTAR
LIGHT ARMORED VEHICLE RECOVERY
Mobile EW SUPPOrt System, AN/MLQ-36
CARRIER ARMORED COMMAND POST M1068A3
CARRIER COMMAND POST FT M577A3
CARRIER CARGO TRACKED 6TON M548A3
ARMORED RECON AB ASSAULT VEH M551A1
CARRIER SMOKE GENERATOR FT M1059A3
CARRIER MORTAR 120MM M1064A3

\section{Service}

USA

USA

USA

USA

USA

USA

USA

USA

USA

Average Inventory

5,451

Service

USMC

USMC

USMC

USMC

USA

USMC

USMC

USMC

USA

USA

USA

USA

USA

USA
Fuel Usage

(gal)

6,065

5,632

4,451

1,294

900

77

43

40

2

Fuel Consumption

$4,812,455$

$\%$ of Total
$5.6 \%$

$\%$ of Total
$5.6 \%$

Activity

Inventory

23,467 miles

21,792 miles

23,300 miles

6,772 miles

4,713 miles

402 miles

226 miles

207 miles

8 miles

Running

Total

$59.7 \%$

\section{Fuel Usage} (gal)

1,995,654

700,066

458,437

441,783

429,299

245,779

190,808

120,528

87,542

72,163

46,033

20,043

4,320

0
Activity

479,418 hours

122,354 hours

78,665 hours

59,941 hours

734,762 miles

43,182 hours

7,246 hours

149,831 miles

123,510 miles

78,787 miles

27,444 miles

7,393 miles

117,741 miles
40,343 hours
Inventory

361

91

90

49

3,066

47

35

6

451

351

773

77

54

0 


$\begin{array}{lc}\text { Manufacturer } & \text { Model } \\ \text { CUMMINS ENGINE } & 6 C T A 8.3\end{array}$

Equipment using this Engine

Nomenclature
TRUCK CARGO 5TON DROPSIDE M923A2
TRUCK TRACTOR 5TON M931A2
TRUCK DUMP 5TON M929A2
TRUCK CARGO 5TON DROPSIDE WW M925A2
TRUCK WRECKER 5TON WW M936A2
TRUCK TRACTOR 5TON WW M932A2
ARMORED SECURITY VEHICLE M1117
TRUCK VAN EXPANSIBLE 5TON M934A2
TRUCK CARGO 5TON XLWB M927A2
TRUCK DUMP 5TON WW M930A2
TRUCK CARGO 5TON XLWB WW M928A2

Average Inventory

12,142

Service

USA

USA

USA

USA

USA

USA

USA

USA

USA

USA

USA
Fuel Consumption
4,409,017

$\%$ of Total

Running

Total

$5.2 \%$

$64.9 \%$

\section{Fuel Usage} (gal)

Activity

Inventory

$2,040,788$

10,684,124 miles

5,687

$1,091,093$

$5,712,191$ miles

2,755

369,062

$1,932,149$ miles

912

358,786

$1,878,350$ miles

1,108

175,667

919,670 miles

629

114,609

600,012 miles

251

90,763

85,543

77,672 miles

32

447,843 miles

461

32,458

169,925 miles

116

32,282

169,006 miles

103

17,967

94,060 miles

88 


\begin{tabular}{|c|c|c|c|c|}
\hline Manufacturer & $\begin{array}{l}\text { Average } \\
\text { Inventory }\end{array}$ & Fuel Consumption & $\%$ of Total & $\begin{array}{l}\text { Running } \\
\text { Total }\end{array}$ \\
\hline CATERPILLAR & 5,017 & $3,822,348$ & $4.5 \%$ & $69.3 \%$ \\
\hline \multicolumn{5}{|l|}{ Equipment using this Engine } \\
\hline Nomenclature & Service & $\begin{array}{c}\text { Fuel Usage } \\
\text { (gal) }\end{array}$ & Activity & Inventory \\
\hline LIGHT ARMORED VEH INFANTRY CARRIER M1126 & USA & $1,131,193$ & 264,242 miles & 122 \\
\hline TRUCK CARGO MTV M1083A1 & USA & 720,045 & $3,769,647$ miles & 1,584 \\
\hline TRUCK TRACTOR MTV M1088A1 & USA & 653,007 & $3,418,682$ miles & 1,315 \\
\hline LIGHT ARMORED VEHICLE MORTAR CARR IVC M112 & 29 USA & 228,754 & 53,436 miles & 30 \\
\hline TRUCK CARGO LMTV M1078A1 & USA & 172,944 & $1,184,003$ miles & 857 \\
\hline LIGHT ARMORED VEHICLE RECON ICV M1127 & USA & 168,304 & 39,315 miles & 32 \\
\hline LIGHT ARMORED VEHICLE ATGM ICV M1134 & USA & 166,386 & 38,867 miles & 32 \\
\hline LIGHT ARMORED VEHICLE COMMANDER'S VEH M113 & 30 USA & 130,653 & 30,520 miles & 20 \\
\hline TRUCK WRECKER MTV WW M1089A1 & USA & 90,551 & 474,059 miles & 229 \\
\hline TRUCK CARGO MTV W/MHE M1084A1 & USA & 76,795 & 402,042 miles & 217 \\
\hline LIGHT ARMORED VEHICLE MEDEVAC M1133 ICV & USA & 61,324 & 14,325 miles & 16 \\
\hline TRUCK CARGO MTV WW M M1083A1 & USA & 60,383 & 316,124 miles & 169 \\
\hline \multicolumn{2}{|l|}{ LIGHT ARMORED VEHICLE FIRE SPT (FSV)(ICV) M1131 USA } & 59,098 & 13,805 miles & 14 \\
\hline TRUCK CARGO MTV LWB M1085A1 & USA & 40,741 & 213,291 miles & 66 \\
\hline LIGHT ARMORED VEHICLE ENGINEER SPT VEH M113 & 32 USA & 24,662 & 5,761 miles & 7 \\
\hline TRUCK CARGO LMTV WW M1078A1 & USA & 19,864 & 135,995 miles & 149 \\
\hline TRUCK CARGO LMTV WW M1079A1 & USA & 10,352 & 70,871 miles & 111 \\
\hline TRUCK DUMP MTV M1090A1 & USA & 5,517 & 28,881 miles & 40 \\
\hline TRUCK DUMP MTV WW M1090A1 & USA & 1,776 & 9,297 miles & 7 \\
\hline
\end{tabular}


Manufacturer
CATERPILLAR

Model

3116 ATAAC

Equipment using this Engine

Nomenclature
TRUCK CARGO LMTV M1078
TRUCK CARGO 21/2TON M35A3
TRUCK CARGO MTV M1083
TRUCK TRACTOR MTV M1088
TRUCK CARGO LMTV LAPES/AD M1081
TRUCK CARGO 21/2TON WW M35A3
TRUCK CARGO LMTV WW M1078
TRUCK CARGO MTV WW M1083
TRUCK CARGO MTV LAPES/AD M1093
TRUCK CARGO MTV W/MHE M1084
TRUCK DUMP MTV M1090
TRUCK WRECKER MTV WW M1089
TRUCK CARGO LMTV LAPES/AD WW M1081
TRUCK DUMP MTV LAPES/AD M1094
TRUCK CARGO 21/2TON D/S M35A3C
TRUCK CARGO MTV LAPES/AD WW M1093
TRUCK CARGO MTV LWB W/MHE M1086
TRUCK TRACTOR MTV WW M1088
TRUCK CARGO 21/2TON LWB M36A3
TRUCK CARGO MTV LWB M1085
TRUCK CARGO 21/2TON D/S WW M35A3C
TRUCK DUMP MTV LAPES/AD WW M1094
TRUCK DUMP MTV WW M1090
TRUCK CARGO 21/2TON LWB WW M36A3 CARGO MTV LWB WW M1085
TRUCK

Average Inventory

11,952

Service

USA

USA

USA

USA

USA

USA

USA

USA

USA

USA

USA

USA

USA

USA

USA

USA

USA

USA

USA

USA

USA

USA

USA

USA

USA
Fuel Consumption
$3,536,020$
$\%$ of Total
$4.1 \%$

Running

Total

$73.5 \%$

\section{Fuel Usage} (gal)

$1,251,038$

512,820

403,504

302,283

212,884

126,307

111,270

104,476

89,858

89,388

63,454

60,336

57,677

50,194

31,343

15,098

14,160

9,351

7,827

7,818

5,363

5,025

2,467

1,540

540

\section{Inventory}

4,043

2,665

770

818

608

671

382

249

267

154

228

208

147

150

200

72

36

50

66

42

77

15

6

24

4 


Manufacturer
CUMMINS ENGINE
Equipment using this Engine
Nomenclature
INFANTRY FIGHTING VEHICLE M2A2 HS
CAVALRY FIGHTING VEHICLE M3A2
INFANTRY FIGHTING VEHICLE M2A3
MULTIPLE LAUNCH ROCKET SYSTEM M993
CAVALRY FIGHTING VEHICLE M3A3
BRADLEY - LINEBACKER
INFANTRY FIGHTING VEHICLE M2
CAVALRY FIGHTING VEHICLE M3A1

$\begin{array}{lc}\text { Manufacturer } & \text { Model } \\ \text { ALLIS CHALMERS } & 3500\end{array}$

Equipment using this Engine

Nomenclature

GEN ST DED 60KW 60HZ MEP006A

GEN ST DED 60KW 400HZ MEP115A

$\begin{array}{lr}\text { Manufacturer } & \text { Model } \\ \text { DETROIT DIESEL } & 8 \mathrm{~V}-92\end{array}$

Equipment using this Engine

Nomenclature

LOGISTICS VEHICLE SYSTEM 12 1/2 TON MK 48

$\begin{array}{lc}\text { Manufacturer } & \text { Model } \\ \text { CUMMINS ENGINE } & \text { VT400 }\end{array}$

Equipment using this Engine

\author{
Nomenclature \\ ASSAULT AMPHIBIOUS VEHICLE, PERSONNEL \\ AAVP7A1 (2) \\ ASSAULT AMPHIBIOUS VEHICLE, RECOVERY \\ AAVR7A1 (2) \\ ASSAULT AMPHIBIOUS VEHICLE, COMMAND \\ AAVC7A1 (1)
}

$\begin{gathered}\text { Average } \\ \text { Inventory }\end{gathered}$
3,493
Service
USA
USA
USA
USA
USA
USA
USA
USA

Average Inventory

1,215

Service

Average Inventory

1,298

Service

USMC

Average Inventory

1,161

Service

USMC

USMC

USMC
Fuel Consumption
2,566,129

$\%$ of Total

$3.0 \%$

Running

Total

$76.5 \%$

\section{Fuel Usage (gal)}

$1,615,043$

267,809

252,017

177,110

124,989

95,819

31,705

1,637

Fuel Consumption

$2,554,053$

Fuel Usage
(gal)

2,553,774

279

Fuel Consumption

$2,175,720$

$\begin{gathered}\text { Fuel Usage } \\ \text { (gal) }\end{gathered}$
$2,175,720$
Fuel Consumption
$2,167,047$

Activity

$1,858,209$ hours

Fuel Usage

(gal)

$1,942,158$

124,603

100,286

\section{Activity}

403,284 hours

Inventory

1,040
Inventory

1,298

Running

$\%$ of Total Total

$2.5 \%$

$84.6 \%$

24,229 hours

51

626
621

171

425

67

85

418

80

unning

$79.5 \%$

nventory

609

606

Running

$82.0 \%$

19,840 hours

70 


$\begin{array}{lc}\text { Manufacturer } & \text { Model } \\ \text { CUMMINS ENGINE } & \text { NTC } 400\end{array}$

Equipment using this Engine

Nomenclature
TRUCK TRACTOR LINE HAUL M915A1

TRUCK TRACTOR LINE HAUL M915

TRUCK TRACTOR MET M920

TRUCK DUMP 20TON 12 CU YD C/S M917

CONCRETE MOBILE MIXER TM 8 CU YD M919

DISTRIBUTOR BITUMIN MDL D63 TM M918
Average Inventory

Average Inventory

Equipment using this Engine

Nomenclature

GEN ST DED 30KW 60HZ MEP 005A

GEN ST DED 30KW 400HZ MEP114A
3,820

Service

USA

USA

USA

USA

USA

USA

1,439

$$
\begin{array}{r}
\text { Fuel Consumption } \\
1,893,010
\end{array}
$$$$
\% \text { of Total }
$$$$
2.2 \%
$$

Running

Total

$86.8 \%$

$$
\begin{gathered}
\text { Fuel Usage } \\
\text { (gal) }
\end{gathered}
$$

$$
1,112,346
$$$$
380,276
$$$$
215,250
$$

153,608

28,956

2,575

\section{Fuel Consumption}

$1,127,779$

Activity

Inventory

$6,187,423$ miles $\quad 1,803$

$2,115,284$ miles

764

1,197,327 miles $\quad 707$

501,978 miles

408

161,066 miles

14,324 miles

87

51

Running

Total

$1.3 \%$

$88.1 \%$

Service

Fuel Usage (gal)

Activity

Inventory

USMC

$1,127,608$

171
719,144 hours

60 hours
1,010

429 


Manufacturer
CONTINENTAL

\section{Model}

LDS465-1

Equipment using this Engine

Nomenclature

TRUCK CARGO 21/2TON M35A2

TRUCK TRACTOR 5TON M52A2

TRUCK DUMP 5TON M51A2

TRUCK DUMP 5TON WW M51A2

TRUCK CARGO 21/2TON M35A1

TRUCK CARGO 5TON LWB M54A2

TRUCK TRACTOR 5TON WW M52A2

TRUCK CARGO 5TON LWB WW M54A2

TRUCK CARGO 5TON XLWB WW M55A2

TRUCK CARGO 5TON LWB M54

TRUCK TRACTOR 5TON WW M52

TRUCK CARGO 5TON DROPSIDE M54A1C

TRUCK CARGO 5TON LWB WW M54

TRUCK CARGO 5TON LWB M54A1

TRUCK TRACTOR 5TON M52

TRUCK TRACTOR 5TON M52A1

Generic TRUCK CARGO 5TON M54-LDS465-1

TRUCK CARGO 21/2TON WW M35A1

\section{Manufacturer \\ Model \\ ONAN DIV \\ DN4M1 \\ Equipment using this Engine}

Nomenclature

GEN ST DED 10KW 60HZ MEP803A

GEN ST DED 10KW 400HZ MEP-813A

GEN ST DED 10KW 60HZ TQ MEP803A

GEN ST DED 10KW 400HZ TQ MEP813A
Average Inventory

10,036

Service

USA

USA

USA

USA

USA

USA

USA

USA

USA

USA

USA

USA

USA

USA

USA

USA

USA

USA

Average Inventory

3,864

Service

USMC

USMC

USA

USA

$$
\begin{array}{r}
\text { Fuel Consumption } \\
1,018,161
\end{array}
$$

$\%$ of Total

$1.2 \%$

Total

$89.3 \%$

\section{Fuel Usage} (gal)

$1,004,378$

5,364

3,427

2,717

1,266

431

263

261

48

2

2

1

0

0

0

0

0

0

0

Fuel Consumption

$1,004,081$

Running Total

$90.5 \%$

$$
1.2 \%
$$

\begin{tabular}{rr}
\multicolumn{1}{l}{ Activity } & Inventory \\
$8,126,330$ miles & 9,700 \\
26,522 miles & 157 \\
16,946 miles & 66 \\
13,432 miles & 37 \\
10,241 miles & 8 \\
2,133 miles & 19 \\
1,299 miles & 11 \\
1,292 miles & 11 \\
236 miles & 3 \\
9 miles & 7 \\
9 miles & 3 \\
4 miles & 2 \\
2 miles & 2 \\
2 miles & 2 \\
2 miles & 2 \\
2 miles & 2 \\
2 miles & 2 \\
2 miles & 2
\end{tabular}

$\begin{gathered}\text { Fuel Usage } \\ \text { (gal) }\end{gathered}$
993,789
10,248
32
12

Activity

$1,316,152$ hours

19,573 hours

32 hours

12 hours
Inventory

1,213

130

2,278

243 


$\begin{gathered}\text { Manufacturer } \\ \text { CONTINENTAL } \\ \text { Equipment using this Engine }\end{gathered}$
Nomenclature
RECOVERY VEHICLE MEDIUM M88A1
RECOVERY VEH MEDIUM FULL TRACK M88A
RECOVERY VEHICLE HEAVY M88A2
Manufacturer
GENERAL MOTORS

Equipment using this Engine

Nomenclature

TRUCK UTIL HVY VARNT HMMWV M1097A2

TRUCK UTIL EXP CAPACITY UP-ARMORED HMMWV

M1114

TRUCK UTIL ARMT CARR ARMORED HMMWV M1025A2 USA

TRUCK AMBULANCE 4LTR HMMWV M997A2

TRUCK UTIL UP-ARMORED HMMWV M1109

$\begin{array}{lc}\text { Manufacturer } & \text { Model } \\ \text { JOHN DEERE } & 6059 T\end{array}$

Equipment using this Engine

Nomenclature

TRUCK FORKLIFT EXTENDABLE B

MEP-816A 400HZ (60 KW GENERATOR)

GEN ST DED 60KW 60HZ TQ MEP806A

GEN ST DED 60KW 400HZ TQ MEP816A

TRUCK FL DED 10000 LB ROUGH TERRAIN(1)

$\begin{array}{lc}\text { Manufacturer } & \text { Model } \\ \text { DETROIT DIESEL } & \text { DDEC II }\end{array}$

Equipment using this Engine

Nomenclature
TRUCK TRACTOR LINE HAUL M915A2
TRUCK DUMP 20TON 12 CU YD C/S M917A1
TRUCK DUMP 20TON 12 CU YD C/S M917A1 W/MCS

USA

USA

Average Inventory

1,889

Service

USA

USMC

USA

Average Inventory

5,701

\section{Service}

USA

USA

Average Inventory

2,453

Service

USMC

USMC

USA

USA

USA

Average Inventory

$$
1,375
$$

Service

USA

USA

USA
Fuel Consumption

899,277

$\%$ of Total

$1.1 \%$

$91.5 \%$

\section{Fuel Usage}

$$
\text { (gal) }
$$

524,348

270,641

104,289

Fuel Consumption

823,044

\section{Fuel Usage}

(gal)

338,584

334,581

149,878

1

0

Fuel Consumption

660,040

\section{Fuel Usage}

(gal)

357,544

302,327

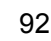

41

37

Fuel Consumption

618,550

$\begin{array}{rr}\text { Activity } & \text { Inventory } \\ 263,655 \text { miles } & 1,706 \\ 24,676 \text { hours } & 62 \\ 52,439 \text { miles } & 121\end{array}$

Running

Total

$92.5 \%$

$\begin{array}{lr}\text { Activity } & \text { Inventory } \\ 5,022,335 \text { miles } & 3,562 \\ 4,962,948 \text { miles } & 1,402\end{array}$

$2,223,185$ miles

732

8 miles

4 miles

$\%$ of Total

$0.8 \%$

Running Total

$93.2 \%$

\begin{tabular}{rr}
\multicolumn{1}{c}{ Activity } & Inventory \\
227,183 hours & 492 \\
158,341 hours & 121 \\
20 hours & 623 \\
8 hours & 200 \\
33 hours & 1,017 \\
& $\begin{array}{c}\text { Running } \\
\text { Total }\end{array}$ \\
$0.7 \%$ & $94.0 \%$
\end{tabular}

Fuel Usage (gal)

Activity

Inventory

384,676

2,139,761 miles

763

188,327

$1,047,569$ miles

462

45,547 


$\begin{array}{lc}\text { Manufacturer } & \text { Model } \\ \text { JOHN DEERE } & 64666.8 \mathrm{~L} \\ \text { Equipment using this Engine } & \\ \text { Nomenclature } & \\ \text { TRACTOR RT ARTICULAT, STR } 6 \text { LOADER SCOOP } \\ \text { TYPE }\end{array}$

$\begin{array}{lc}\text { Manufacturer } & \text { Model } \\ \text { CONTINENTAL } & \text { LD465-1 }\end{array}$

Equipment using this Engine

Nomenclature
TRUCK CARGO 21/2TON WW M35A2
TRUCK VAN SHOP 21/2TON M109A3
TRUCK CARGO 21/2TON D/S M35A2C
TRUCK VAN SHOP 21/2TON WW M109A3
TRUCK CARGO 21/2TON XLWB M36A2
Generic TRUCK CARGO 21/2TON M35-LD465-1
TRUCK CARGO 21/2TON D/S WW M35A2C
TRUCK CARGO 21/2TON XLWB WW M36A2
TRUCK TANK FS 21/2TON M49A2C
TRUCK TANK WATER 21/2TON M50A3
TRUCK TANK WATER 21/2TON M50A2
TRUCK TANK FS 21/2TON M49A1C
TRUCK TANK FS 21/2TON WW M49A2C

$\begin{array}{rrrr}\begin{array}{c}\text { Average } \\ \text { Inventory }\end{array} & \text { Fuel Consumption } & \text { \% of Total } & \begin{array}{l}\text { Running } \\ \text { Total }\end{array} \\ 499 & 615,823 & 0.7 \% & 94.7 \%\end{array}$

Service

USMC

Average Inventory

6,278

Fuel Consumption

610,581 (gal)

615,823
$\%$ of Total

$0.7 \%$

Fuel Usage

Activity

182,300 hours

Inventory 499

Running Total

$95.4 \%$

$\begin{gathered}\text { Fuel Usage } \\ \text { (gal) } \\ 362,237 \\ 134,003 \\ 85,722 \\ 12,361 \\ 6,434 \\ 5,156 \\ 1,967 \\ 1,176 \\ 1,110 \\ 414 \\ 2 \\ 0 \\ 0\end{gathered}$

$\begin{array}{rr}\text { Activity } & \text { Inventory } \\ 2,930,823 \text { miles } & 3,715 \\ 1,084,203 \text { miles } & 1,174 \\ 693,572 \text { miles } & 962 \\ 100,009 \text { miles } & 46 \\ 52,057 \text { miles } & 114 \\ 41,719 \text { miles } & 90 \\ 15,912 \text { miles } & 44 \\ 9,511 \text { miles } & 37 \\ 8,983 \text { miles } & 54 \\ 3,349 \text { miles } & 33 \\ 13 \text { miles } & 5 \\ 4 \text { miles } & 2 \\ 2 \text { miles } & 2\end{array}$




Manufacturer
DETROIT DIESEL
Equipment using this Engine
Nomenclature
CARRIER PERSONNEL FT M113A2
CARRIER COMMAND POST FT M577A2
CARRIER PERSONNEL FIRE SPT M981
CARRIER MORTAR 120MM M1064
COMBAT VEHICLE ANTI-TANK ITV M901A1
CARRIER SMOKE GENERATOR FT M1059
CARRIER FT COMMAND AND CONTROL VEHICLE
C2V M4
CRANE TRUCK MOUNTED 25TON MT250
CARRIER MORTAR 107MM SP M106A2

$\begin{array}{lc}\text { Manufacturer } & \text { Model } \\ \text { CUMMINS ENGINE } & \text { V903C }\end{array}$

Equipment using this Engine

Nomenclature
ARMORED COMBAT EARTHMOVER M9
ARMORED COMBAT EARTHMOVER M9

\section{Manufacturer}

MERCEDES BENZ
Average Inventory

8,420

Service

USA

USA

USA

USA

USA

USA

USA

USA

USA

Average Inventory

408

Service

USMC

USA

Average

Inventory

1,901

Equipment using this Engine

Nomenclature

TRACTOR WHEEL DED 4X4 EXCAVATOR FLU419

TRACTOR WHEEL DED 4X4 EXCAVATOR

TRACTOR WHEEL DED 4X4 HMMH FLU10344

$\begin{array}{lr}\text { Manufacturer } & \text { Model } \\ \text { CATERPILLAR } & 3306\end{array}$

Equipment using this Engine

\author{
Nomenclature \\ TRACTOR, MED, FULL TRACK, D \\ TRACTOR FT DED D7H
}

Service

USMC

USA

USA

Average Inventory

278

Service

USMC

USA
Fuel Consumption
442,514

$\%$ of Total

Running

$0.5 \%$

$95.9 \%$

Fuel Usage

$$
\text { (gal) }
$$

225,921

114,252

46,693

39,838

9,641

4,998

932

232

6

Fuel Consumption

429, 250

\begin{tabular}{rr}
\multicolumn{1}{c}{ Activity } & Inventory \\
386,672 miles & 3,344 \\
195,547 miles & 2,866 \\
74,208 miles & 792 \\
68,185 miles & 553 \\
16,501 miles & 527 \\
8,555 miles & 102 \\
798 miles & 10 \\
& 220 \\
68 hours & 6 \\
10 miles & Running \\
$\%$ of Total & Total \\
$0.5 \%$ & $96.4 \%$
\end{tabular}

Fuel Usage

(gal)
316,284
112,966

Activity

76,624 hours

Inventory

84,487 miles

101

307

Running

Fuel Consumption

$\%$ of Total

Total

$96.9 \%$

$\begin{gathered}\text { Fuel Usage } \\ \text { (gal) }\end{gathered}$
409,178
101
38

400,886

\section{Fuel Usage} (gal)

400,861

25
Activity

124,308 hours

32 hours

12 hours

$\%$ of Total

$0.5 \%$

Activity

88,939 hours

4 hours
Inventory

120

1,669

112

Running

Total

$97.4 \%$

Inventory

245

33 


$\begin{array}{lr}\text { Manufacturer } & \text { Mode } \\ \text { CATERPILLAR } & 3208\end{array}$

Equipment using this Engine

Nomenclature

CRANE HIGH SPEED

$\begin{array}{lr}\text { Manufacturer } & \text { Model } \\ \text { JI CASE } & \text { G188D } \\ & \text { Equipment using this Engine }\end{array}$

Nomenclature

TRACTOR, FULL TRACK, 1150E

Manufacturer

Model

DETROIT DIESEL

$8 V 71 T$

Equipment using this Engine

Nomenclature

HOWITZER MEDIUM SP 155MM M109A6

HOWITZER MEDIUM SP 155MM M109A5

CARRIER CARGO AMMO FT M992A1

RECOVERY VEHICLE LIGHT M578

HOWITZER HEAVY SP 8IN M110A2

$\begin{array}{lr}\text { Manufacturer } & \text { Model } \\ \text { ONAN DIV } & \text { Q106M } \\ \text { Equipment using this Engine }\end{array}$

Nomenclature

GEN ST DED 3KW 60HZ MEP 16B

GEN ST DED 3KW 60HZ

GEN ST DED 3KW 60HZ MEP016B

$\begin{array}{lc}\text { Manufacturer } & \text { Model } \\ \text { PERKINS } & 704-30 T \\ & \text { Equipment using this Engine }\end{array}$

Nomenclature

TRUCK, FORKLIFT LCRT 4000 LBS
Average Inventory

$$
126
$$

$$
\text { Service }
$$

USMC

Average Inventory

152

$$
\begin{aligned}
& \text { Service } \\
& \text { USMC }
\end{aligned}
$$

Average Average
Inventory

1,592

Service
USA
USA
USA
USA
USA

Average Inventory

3,737

Service
USMC
USA
USA

Average Inventory

$$
431
$$

Service

USMC
Fuel Consumption

321,888

$$
\begin{gathered}
\begin{array}{c}
\text { Fuel Usage } \\
\text { (gal) }
\end{array} \\
321,888
\end{gathered}
$$

Fuel Consumption

285,250

$$
\begin{gathered}
\begin{array}{c}
\text { Fuel Usage } \\
\text { (gal) }
\end{array} \\
285,250
\end{gathered}
$$

Fuel Consumption

278,067

Fuel Usage

$$
\text { (gal) }
$$

211,409

40,704

21,660

4,290

4

Fuel Consumption

241,344

Fuel Usage

$$
\text { (gal) }
$$

241,309

22

13

Fuel Consumption

206,630
$\%$ of Total

$0.4 \%$

ning

Total

$97.7 \%$

\begin{tabular}{cr}
\multicolumn{1}{|l}{ Activity } & $\begin{array}{r}\text { Inventory } \\
92,948 \text { hours }\end{array}$ \\
\% of Total & $\begin{array}{l}\text { Running } \\
\text { Total }\end{array}$ \\
\hline
\end{tabular}

$98.1 \%$

\begin{tabular}{rr}
\multicolumn{1}{|l}{ Activity } & $\begin{array}{r}\text { Inventory } \\
83,431 \text { hours }\end{array}$ \\
$\%$ of Total & $\begin{array}{l}\text { Running } \\
\text { Total }\end{array}$ \\
$0.3 \%$ & $98.4 \%$
\end{tabular}

Activity

Inventory

235,193 miles $\quad 623$

45,283 miles $\quad 556$

21,906 miles $\quad 34$

4,492 miles $\quad 377$

3 miles

2

Running

$\%$ of Total

Total

$0.3 \%$

$98.7 \%$

\section{Activity}

Inventory

768,720 hours

1,359

36 hours

376

40 hours

2,002

Running

$\%$ of Total

Total

$0.2 \%$

$98.9 \%$

Fuel Usage (gal)

Activity

Inventory

206,630 


$\begin{array}{lr}\text { Manufacturer } & \text { Model } \\ \text { CATERPILLAR } & 3304\end{array}$

Equipment using this Engine

Nomenclature

GRADER RD MOTOR, 130-G

ROLLER COMPACTOR 563D

GRADER ROAD MTRZD DED MDL CAT130G

LOADER SCOOP TYPE DED 950BNS

$\begin{array}{lr}\text { Manufacturer } & \text { Model } \\ \text { CATERPILLAR } & 3408 T\end{array}$

Equipment using this Engine

Nomenclature

TRUCK FL 50000 LB CONTAINER HANDLER

TRUCK FL 50000LB CONT HDLR DV43 RT

$\begin{array}{ll}\text { Manufacturer } & \text { Model } \\ \text { CONTINENTAL } & \text { AVDS1790-2DA }\end{array}$

Equipment using this Engine

Nomenclature

BRIDGE ARMORED, M60A1 SCISS

$\begin{array}{lr}\text { Manufacturer } & \text { Model } \\ \text { JOHN DEERE } & 4039 T\end{array}$

Equipment using this Engine

Nomenclature

GEN, MEP-114A (30 KW GENERATOR)

GEN ST DED 30KW 50/60HZ TQ MEP805A

TRACTOR FT DED MDL 550C

GEN ST DED 30KW 400HZ TQ MEP815A

$\begin{array}{ll}\text { Manufacturer } & \text { Model } \\ \text { CONTINENTAL } & \text { AVDS1790-2D }\end{array}$

Equipment using this Engine

Nomenclature

BRIDGE LAUNCHER M48/M60 TANK SERIES
Average Inventory

$$
1,590
$$

Service

USMC

USMC

USA

USA

Average Inventory

$$
421
$$

Service
USMC
USA

Average Inventory

24

Service

USMC

Average Inventory

795

Service
USMC
USA
USA
USA

Average Inventory

415

Service

USA
Fuel Consumption

199,456

Fuel Usage

(gal)

186,098

13,064

176

118

Fuel Consumption

160,027

Fuel Usage

(gal)

159,964

63

Fuel Consumption

125,688

Fuel Usage

(gal)

125,688

Fuel Consumption

109,676

Fuel Usage (gal)

109,618

27

22

8

Fuel Consumption

105,966

Fuel Usage

(gal)

105,966
$\%$ of Total

$0.2 \%$

Running
Total

$99.2 \%$

$\begin{array}{rr}\text { Activity } & \text { Inventory } \\ 70,922 \text { hours } & 105 \\ 6,750 \text { hours } & 45 \\ 28 \text { hours } & 1,270 \\ 14 \text { hours } & 170 \\ \% \text { of Total } & \begin{array}{c}\text { Running } \\ \text { Total }\end{array} \\ 0.2 \% & 99.3 \%\end{array}$

Activity

Inventory

31,630 hours

12 hours

87

334

Running

$\%$ of Total Total

$0.1 \%$

$99.5 \%$

\begin{tabular}{rr}
\multicolumn{1}{l|}{ Activity } & Inventory \\
17,032 hours & 24 \\
$\%$ of Total & $\begin{array}{l}\text { Running } \\
\text { Total }\end{array}$ \\
$0.1 \%$ & $99.6 \%$
\end{tabular}

Activity Inventory

91,802 hours $\quad 64$

11 hours $\quad 637$

7 hours 20

3 hours

74

$\%$ of Total

Running

$0.1 \%$

$99.7 \%$

Activity Inventory

50,704 miles $\quad 415$ 


\begin{tabular}{|c|c|c|}
\hline Manufacturer & Model & $\begin{array}{l}\text { Average } \\
\text { Inventory }\end{array}$ \\
\hline CUMMINS ENGINE & $4 B 3.9$ & 2,385 \\
\hline \multicolumn{3}{|c|}{ Equipment using this Engine } \\
\hline \multicolumn{2}{|c|}{ Nomenclature } & Service \\
\hline \multicolumn{2}{|c|}{ CRANE, RT, LIGHT HYDRAULIC } & USMC \\
\hline \multicolumn{2}{|c|}{ TRUCK FL DED 4000LB RT MDL MK4 } & USA \\
\hline
\end{tabular}

CRANE WHEEL MTD HYD LT 7-1/2 TON LRT 110 W/CABUSA

$\begin{array}{lr}\text { Manufacturer } & \text { Model } \\ \text { JI CASE } & 6 T 590\end{array}$

Equipment using this Engine

Nomenclature
LOADER SCOOP TYPE FT

$\begin{array}{ll}\text { Manufacturer } & \text { Model } \\ \text { MERCEDES BENZ } & \text { OM 603-950 }\end{array}$

Equipment using this Engine

Nomenclature

CARRIER CARGO FT SUSV M973A1

$\begin{array}{lr}\text { Manufacturer } & \text { Model } \\ \text { CATERPILLAR } & 3406\end{array}$

Equipment using this Engine

Nomenclature

SCRAPER-TRACTOR, WHEELED, 6

SCRAPER EARTH MVG SP 621B

$\begin{array}{ll}\text { Manufacturer } & \text { Model } \\ \text { MERCEDES BENZ } & \text { OM402AT }\end{array}$

Equipment using this Engine

Nomenclature

FOX NBC RECON SYSTEM VEHICLE M93A1
Average Inventory 76

Service

USMC

Average Inventory

501

Service

USA

Average Inventory

907

Service
USMC
USA

Average Inventory

70

Fuel Consumption

$$
\text { 23, } 293
$$

Fuel Consumption

$$
37,084
$$

Fuel Usage

$$
\begin{aligned}
& \text { (gal) } \\
& 37,084
\end{aligned}
$$

Fuel Consumption

$$
35,841
$$

Fuel Usage

(gal)

35,841

28,081

Fuel Usage

gal)

27,980

101
Fuel Consumption$$
72,946
$$

$\%$ of Total

$0.1 \%$

Running
Total

Fuel Usage

(gal)

72,700

126

120

Fuel Consumption

Fuel Usage

Service

USA (gal)

23,293

$$
\begin{array}{rr}
\multicolumn{1}{c}{\text { Activity }} & \text { Inventory } \\
75,729 \text { hours } & 144 \\
24 \text { hours } & 1,626 \\
49 \text { hours } & 615 \\
& \begin{array}{c}
\text { Running } \\
\text { Total }
\end{array} \\
\text { \% of Total } & \begin{array}{c}
\text { Total } \% \\
0.0 \%
\end{array}
\end{array}
$$

Activity

Inventory

23,816 hours

76

Running

$\%$ of Total

Total

$0.0 \%$

$99.9 \%$

\section{Activity}

Inventory

109,996 miles

501

Running

$\%$ of Total

Total

$0.0 \%$

$100.0 \%$

\begin{tabular}{rr}
\multicolumn{1}{c}{ Activity } & Inventory \\
5,596 hours & 44 \\
16 hours & 863 \\
$\%$ of Total & $\begin{array}{l}\text { Running } \\
\text { Total }\end{array}$ \\
$0.0 \%$ & $100.0 \%$
\end{tabular}

$\begin{array}{rr}\text { Activity } & \text { Inventory } \\ 71,486 \text { miles } & 70\end{array}$




Manufacturer
DEUTZ

Equipment using this Engine

Nomenclature

DITCHING MACHINE

Manufacturer
ONAN DIV
Equipment using this Engine

Nomenclature

SEMITRAILER TANK 5000 GAL M970

Manufacturer

Model

YORK SHIPLEY

$V Y-7-8 D D$

Equipment using this Engine

Nomenclature

BATH, SHOWER UNIT

$\begin{array}{cc}\text { Manufacturer } & \text { Model } \\ \text { CUMMINS ENGINE } & 6 B T 5.9-C \\ \text { Equipment using this Engine }\end{array}$

Nomenclature

TRUCK FL DED 6000LB AMMO HDLG VRRTF

$\begin{array}{lr}\text { Manufacturer } & \text { Model } \\ \text { CATERPILLAR } & 3306 T\end{array}$

Equipment using this Engine

Nomenclature

TRACTOR FT DED D7F DV29

$\begin{array}{lr}\text { Manufacturer } & \text { Model } \\ \text { DETROIT DIESEL } & 453 \mathrm{~N}\end{array}$

Equipment using this Engine

Nomenclature

TRUCK FL DED 6000LB MLT-6
Average Inventory

50

Service

USMC

Average Inventory

308

Service

USMC

Average Inventory

192

Service

USMC

Average Inventory

$$
1,437
$$

Service

USA

Average Inventory

888

Service

USA

Average Inventory

346

Service

USA
Fuel Consumption

8,279

Fuel Usage

(gal)

8,279

Fuel Consumption

5,487

Fuel Usage

(gal)

5,487

Fuel Consumption

1,226

Fuel Usage

(gal)

1,226

Fuel Consumption

325

Fuel Usage (gal)

325

Fuel Consumption

309

Fuel Usage (gal)

309

Fuel Consumption

294

Fuel Usage

(gal)

294

$\begin{array}{cc}\% \text { of Total } & \begin{array}{l}\text { Running } \\ \text { Total }\end{array} \\ 0.0 \% & 100.0 \%\end{array}$

\begin{tabular}{cr} 
Activity & Inventory \\
25,968 hours & 50 \\
$\%$ of Total & $\begin{array}{l}\text { Running } \\
\text { Total }\end{array}$ \\
\hline
\end{tabular}

$0.0 \%$

$100.0 \%$

\begin{tabular}{rr}
\multicolumn{1}{c}{ Activity } & Inventory \\
9,430 hours & 308 \\
$\%$ of Total & $\begin{array}{l}\text { Running } \\
\text { Total }\end{array}$
\end{tabular}

$0.0 \% \quad 100.0 \%$

Activity Inventory

514 hours $\quad 192$

$\%$ Running

Total

$$
0.0 \% \quad 100.0 \%
$$

Activity Inventory

62 hours $\quad 1,437$

$\begin{array}{cc}\% \text { of Total } & \begin{array}{l}\text { Running } \\ \text { Total }\end{array} \\ 0.0 \% & 100.0 \%\end{array}$

Activity Inventory

49 hours $\quad 888$

$\%$ of Total Running

$0.0 \% \quad 100.0 \%$

Activity Inventory

56 hours $\quad 346$ 


$\begin{array}{lr}\text { Manufacturer } & \text { Model } \\ \text { CATERPILLAR } & \text { D342 }\end{array}$

Equipment using this Engine

Nomenclature

TRACTOR FT DED CAT D8K-8 S-8

\begin{tabular}{lr} 
Manufacturer & Model \\
JI CASE & $504 B D$ \\
\multicolumn{3}{c}{ Equipment using this Engine }
\end{tabular}

Nomenclature

LOADER SCOOP TYPE DED JI CASE MW24C

$\begin{array}{ll}\text { Manufacturer } & \text { Model } \\ \text { DETROIT DIESEL } & 6 V 92 T C / 6-71\end{array}$

Equipment using this Engine

Nomenclature

CRANE TRUCK MOUNTED 140T

$\begin{array}{lc}\text { Manufacturer } & \text { Model } \\ \text { CATERPILLAR } & D 333 C T\end{array}$

Equipment using this Engine

Nomenclature
TRACTOR FT DED LW SP(1)
TRACTOR FT DED D7R

Manufacturer

Model

ONAN DIV

DJC99E/9487

Equipment using this Engine

Nomenclature

GEN ST DED 10KW 60HZ MEP003A
Average Inventory

167

Service

USA

Average Inventory

1,000

Service

USA

Average Inventory

9

Fuel Consumption

144

Fuel Usage

(gal)

166

Activity

45 hours

Inventory

of Total Total

$0.0 \% \quad 100.0 \%$

Fuel Usage

227

Activity

36 hours

Inventory

167

Running

Total

$0.0 \% \quad 100.0 \%$

$\%$ of Total

Running

$0.0 \%$

Tota

Service
USA

Average Inventory

1,183

Fuel Consumption

126

Fuel Usage

Service

USA

USA

Average Inventory

$$
1,486
$$

Fuel Consumption

123

Service

USA

$$
\text { (gal) }
$$

126

0

123

\section{Fuel Usage}

(gal)

123
Activity Inventory

20 hours $\quad 1,165$

0 hours 18

$\%$ of Total Running

$0.0 \% \quad 100.0 \%$

Activity Inventory

100 hours $\quad 1,486$ 


\section{Manufacturer \\ CONTINENTAL}

Model

AVDS1790-2C

Equipment using this Engine

Nomenclature

TANK COMBAT 105MM M60A3 (TTS)
Average

Inventory

7

Service

USA

Fuel Consumption
119

$\%$ of Total

$0.0 \%$

$100.0 \%$

Fuel Usage

(gal)

119
Activity

57 miles
Inventory

7 


$\begin{array}{lr}\text { Manufacturer } & \text { Model } \\ \text { CATERPILLAR } & \text { C240 }\end{array}$

Equipment using this Engine

Nomenclature

TRUCK FL DED 4000LB CBD HYS H40XL

\section{Manufacturer \\ Model \\ HERCULES ENGINE \\ D198ERX51 \\ Equipment using this Engine}

\section{Nomenclature}

GEN ST DED 15KW 60HZ PU405

Manufacturer

ISUZU

Equipment using this Engine

Nomenclature

TRUCK FL DED 6000LB CBD HYSTER H60X

GEN ST DED 15KW 50/60HZ TQ MEP804A

GEN ST DED 15KW 400HZ TQ MEP814A

\section{Manufacturer \\ Model \\ INTER HARV \\ $D T-817 C$}

Equipment using this Engine

Nomenclature

LOADER SCOOP TYPE DED BUCK H100CRB

$\begin{array}{lc}\text { Manufacturer } & \text { Model } \\ \text { CATERPILLAR } & 3046 T\end{array}$

Equipment using this Engine

Nomenclature

TRACTOR FT DED D5BS1

$\begin{array}{lc}\text { Manufacturer } & \text { Model } \\ \text { CUMMINS ENGINE } & 6 B T 5.9\end{array}$

Equipment using this Engine

Nomenclature

TRUCK FL DED 4000LB AMMO HDLG VRRTF
Average Inventory

870

Service

USA

Average Inventory

949

Service

USA

Average Inventory

1,416

Service

USA

USA

USA

Average Inventory

59

Service

USA

Average Inventory

55

Service

USA

Average Inventory

1,262

Service

USA
14
Fuel Consumption
67

14
Fuel Consumption
67

Fuel Consumption

84

Fuel Usage

(gal)

84

Fuel Consumption

77

Fuel Usage

(gal)

77

Fuel Consumption

76

Fuel Usage

(gal)

47

15

14
Fuel Consumption
67

Fuel Usage

(gal)

67

Fuel Consumption

67

Fuel Usage (gal)

67

Fuel Consumption

52

(gal)

52
Fuel Usage $\begin{array}{cc}\% \text { of Total } & \begin{array}{l}\text { Running } \\ \text { Total }\end{array} \\ 0.0 \% & 100.0 \%\end{array}$

Activity Inventory

16 hours

870

Running

Total

$\quad 0.0 \% \quad 100.0 \%$

Activity Inventory

50 hours

949

Running

$\%$ of Total Total

$0.0 \% \quad 100.0 \%$

Activity Inventory

9 hours $\quad 572$

10 hours $\quad 472$

8 hours $\quad 372$

Running

$\%$ of Total Total

$0.0 \% \quad 100.0 \%$

Activity Inventory

8 hours $\quad 59$

$\begin{array}{cc}\% \text { of Total } & \begin{array}{l}\text { Running } \\ \text { Total }\end{array} \\ 0.0 \% & 100.0 \%\end{array}$

Activity Inventory

16 hours $\quad 55$

$\%$ of Total Running

$0.0 \% \quad 100.0 \%$

Activity Inventory

10 hours $\quad 1,262$ 


\section{Manufacturer \\ Model \\ DETROIT DIESEL \\ Equipment using this Engine \\ Nomenclature \\ CRANE SHOVEL CRAWLER 40T PH5060}

$\begin{array}{lc}\text { Manufacturer } & \text { Model } \\ \text { CUMMINS ENGINE } & \text { V8 } 2652380\end{array}$

Equipment using this Engine

Nomenclature

CRANE WHEEL MOUNTED M320RT

\begin{tabular}{lr} 
Manufacturer & Model \\
ONAN DIV & $D N 2 M$ \\
\multicolumn{2}{c}{ Equipment using this Engine }
\end{tabular}

Nomenclature

GEN ST DED 5KW 60HZ TQ MEP802A

GEN ST DED 5KW 400HZ TQ MEP812A

$\begin{array}{lc}\text { Manufacturer } & \text { Model } \\ \text { CATERPILLAR } & 3126 \mathrm{HEUI}\end{array}$

Equipment using this Engine

Nomenclature

TRACTOR FULL TRACKED HIGH SPEED (DEUCE)

$\begin{array}{ll}\text { Manufacturer } & \text { Model } \\ \text { CONTINENTAL } & \text { AVDS1790-2A, D, }\end{array}$

Equipment using this Engine

Nomenclature

COMBAT ENGINEER VEHICLE M728

\begin{tabular}{lr} 
Manufacturer & Model \\
ONAN DIV & Q106D \\
\multicolumn{2}{c}{ Equipment using this Engine }
\end{tabular}

Nomenclature

GEN ST DED 3KW 60HZ MEP831
Average Inventory

$$
6
$$

$\begin{array}{rcr}\text { Fuel Consumption } & \begin{array}{c}\text { \% of Total } \\ \text { Running } \\ \text { Total }\end{array} \\ 21 & 0.0 \% & 100.0 \%\end{array}$

$$
\begin{gathered}
\text { Fuel Usage } \\
\text { (gal) }
\end{gathered}
$$

Activity Inventory

USA

21

2 hours

6

Average Inventory

Fuel Consumption

$\%$ of Total Running

24

14

$0.0 \%$

$100.0 \%$

Fuel Usage

Service

USA

(gal)

Activity

Inventory

14

Average Inventory

3,761

Service

USA

USA

Average Inventory

242

Fuel Consumption

12

$$
\begin{array}{cl}
\% \text { of Total } & \begin{array}{l}
\text { Running } \\
\text { Total }
\end{array} \\
0.0 \% & 100.0 \%
\end{array}
$$$$
4 \text { hours }
$$

$\begin{gathered}\text { Fuel Usage } \\ \text { (gal) }\end{gathered}$
12
0

Activity

Inventory

20 hours
0 hours

3,715

Fuel Consumption

$\%$ Running

$0.0 \% \quad 100.0 \%$
Service
USA

Average Inventory

\section{2}

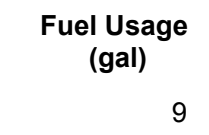

Activity

Inventory
Fuel Consumption
Running
Total

8 hours

242

$0.0 \% \quad 100.0 \%$

Service

Fuel Usage (gal)

Activity

Inventory

USA

4

Average Inventory

Fuel Consumption

2 miles

2

3,989

$\%$ of Total

Running

$0.0 \%$

$100.0 \%$

Service

Fuel Usage

USA (gal)

3
Activity

8 hours
Inventory

3,989 


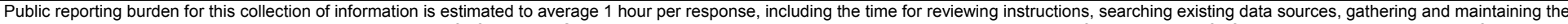

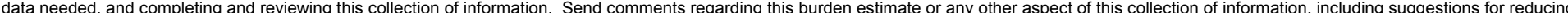

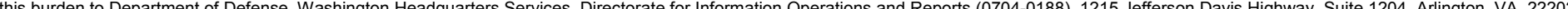

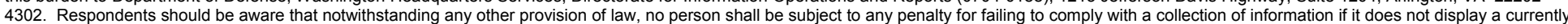
valid OMB control number. PLEASE DO NOT RETURN YOUR FORM TO THE ABOVE ADDRESS.

\begin{tabular}{l|l} 
valid OMB control number. PLEASE DO NOT RETURN YOUR FORM TO THE ABOVE ADDRESS. \\
\hline 1. REPORT DATE (DD-MM-YYYY) & 2. REPORT TYPE
\end{tabular}

\begin{tabular}{c|c}
$03-2006$ & Final \\
\hline
\end{tabular}

4. TITLE AND SUBTITLE

Diesel-Powered Equipment Properties and Activity Database for DoD Off-Road Sources:

SERDP Project WP-1338

3. DATES COVERED (From - To)

5a. CONTRACT NUMBER

5b. GRANT NUMBER

5c. PROGRAM ELEMENT NUMBER

6. AUTHOR(S)

Michael R. Kemme, William T. Brown, Edwin A. Frame, and Ruben A. Alvarez

5d. PROJECT NUMBER

SERDP

5e. TASK NUMBER

5f. WORK UNIT NUMBER

CP-1338

7. PERFORMING ORGANIZATION NAME(S) AND ADDRESS(ES)

U.S. Army Engineer Research and Development Center (ERDC)

8. PERFORMING ORGANIZATION REPORT NUMBER

Construction Engineering Research Laboratory (CERL)

ERDC/CERL TR-06-6

PO Box 9005

Champaign, IL 61826-9005

9. SPONSORING / MONITORING AGENCY NAME(S) AND ADDRESS(ES)

10. SPONSOR/MONITOR'S ACRONYM(S)

Strategic Environmental Research and Development Program

901 North Stuart Street, Suite 203

Arlington, VA 22203-1821

11. SPONSOR/MONITOR'S REPORT NUMBER(S)

12. DISTRIBUTION / AVAILABILITY STATEMENT

Approved for public release; distribution is unlimited.

13. SUPPLEMENTARY NOTES

Copies are available from the National Technical Information Service, 5285 Port Royal Road, Springfield, VA 22161.

\section{ABSTRACT}

A database of Department of Defense diesel engine powered off-road equipment was developed using Microsoft ${ }^{\circledR}$ Access database development tools. The database contains information about fuels, equipment, engines, inventories, usage, and fuel consumption that was obtained from many disparate sources. This database was developed to support the SERDP-funded project Characterization of Off-Road Emissions of Criteria Pollutants (WP-1336). The database was used to prioritize the equipment contained in the WP-1336 test matrix and will later be used as a source of information for the WP-1336 engine emission estimation tool. Data analysis has shown that the top ten fuel consuming engines account for more than 90 percent of fuel usage for the Army and more than 80 percent for the U.S. Marine Corps. Therefore, emission tests performed on a limited number of off-road diesel engines can provide a fairly complete picture of emissions from the entire population of military off-road sources. The database includes an interface that allows users to view data in onscreen forms or analyze data using built-in reports. The database and interface are intended as resources for anyone interested in examining, filtering, querying, or analyzing the collected data.

15. SUBJECT TERMS

military training

emissions

16. SECURITY CLASSIFICATION OF:

a. REPORT Unclassified

\section{b. ABSTRACT}

Unclassified diesel engines

database c. THIS PAGE

Unclassified

\begin{tabular}{|c|c|}
$\begin{array}{l}\text { 17. LIMITATION } \\
\text { OF ABSTRACT }\end{array}$ & $\begin{array}{c}\text { 18. NUMBER } \\
\text { OF PAGES }\end{array}$ \\
SAR & 96
\end{tabular}

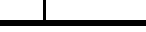

\section{trol}

